\title{
Asia's global expansion: business and financial aspects
}


送 


\section{Economy}

\section{Asia's global expansion: business and financial aspects}

edited by Magdalena Rosińska-Bukowska and Klaudia Zielińska-Lont 


\section{Table of contents}

Introduction

Chapter 1

Asian trade and global value chains (Aleksandra Nacewska-Twardowska) $\quad 9$

1.1. Globalization, global value chains and value added trade $\quad 10$

1.2. Statistical data and methodology $\quad 14$

1.3. Share of Asian economies in international trade $\quad 17$

1.4. Analysis of the largest Asian economies $\quad 21$

Conclusions $\quad 24$

$\begin{array}{ll}\text { Appendix } & 26\end{array}$

Chapter 2

The most powerful Asian transnational corporations

(Magdalena Rosińska-Bukowska) 27

2.1. The determinants of building international competitiveness in the $21^{\text {st }}$ century

- implications for the assessment of development potential of corporations 28

2.2. System of corporation attributes as the foundation of development potential 30

2.3. Systemic nature of corporation capital - layers, parameters, potential assessments 33

2.4. Asia's largest companies in international rankings 37

2.5. Asian corporations in light of the research that utilizes a synthetic measure $\quad 46$

2.6. The most powerful Asian non-financial transnational corporations 53

Conclusions $\quad 56$

Chapter 3

\section{The social network analysis of Chinese cross-border mergers}

and acquisitions (Dominika Brózda-Wilamek)

3.1. The network analysis as the M\&A's research tool $\quad 60$

3.2. Chinese cross-border mergers and acquisitions $\quad 62$

3.3. The results of the Chinese CBM\&As network study using SNA indicators 66

Conclusions

Chapter 4

The role of energy sector in the development of the Chinese economy (Tomasz Motowidlak)

4.1. Primary energy consumption as a determinant of China's economic growth 74

4.2. Electricity consumption as a determinant of the development of China's economy $\quad 77$

4.3. Side effects of China's economic growth 
4.4. Fuel conditioning of electricity generation in China 80

4.5. New priorities in China's power industry 82

4.6. Development of technologies and innovative solutions in China's power industry 83

4.7. China's capital expansion as a form of acquiring modern energy technologies $\quad 85$

Conclusions $\quad 86$

Chapter 5

The comparative analysis for gross domestic product of China and ASEAN member states (Agnieszka Matuszewska-Pierzynka)

5.1. Impact of government expenditure on economic growth - literature review 91

5.2. Research Methodology 95

5.3. Efficiency of general government final consumption expenditure in the creation
of GDP - results of empirical research

$\begin{array}{ll}\text { Conclusions } & 108\end{array}$

Chapter 6

Challenges ahead of the banking sectors in Asia (Klaudia Zielińska-Lont) 111

6.1. Asia's banking sector - overview 112

6.2. Major banking sectors in the region $\quad 113$

$\begin{array}{ll}\text { 6.3. Asian banking sector - status quo } & 115\end{array}$

6.4. Asian banking sector - way forward $\quad 117$

$\begin{array}{lr}\text { Conclusions } & 120\end{array}$

$\begin{array}{lr}\text { Conclusions } & 121\end{array}$

References $\quad 123$

List of figures $\quad 135$

List of tables $\quad 137$ 


\section{Introduction}

The aim of this monography is to highlight the key areas of dynamic development of the Asian economies and to analyse the prospects for reinforcing their position in the modern ( $21^{\text {st }}$ century) global economy. A secondary goal is to underline the fact that a comprehensive analysis of Asia's economic expansion should be considered from a business and a financial perspective in parallel.

The authors of the monography concentrate on the chosen business aspects of Asia's expansion, such as: trade and value chain development, corporations, international mergers and acquisitions, growth potential of the strategic sectors (on the example of energy industry), GDP growth model. In part II, the emphasis is placed on the financial aspects, such as: monetary policy, development of bond markets, largest credit institutions and the challenges ahead of the banking sector.

The first chapter describes changes in trade in Asian countries, which became an important element of global value chains (GVC) at the turn of the $20^{\text {th }}$ and $21^{\text {st }}$ century. These changes are presented using value added trade statistics. This approach makes it possible to present real links between Asian countries and the global economy. The analysis of added value also allows indicating changes in the position of individual Asian countries in GVC.

The second chapter attempts to assess the development determinants and prospects of Asian transnational corporations while taking into account the requirements of building competitiveness in the modern global economy and a specific philosophy of the corporate expansion. Improving position of Asian corporations (A-TNCs) against the most powerful transnational corporations in the world (Top-TNCs) confirms the thesis that Asian economies are implementing modern business development models in line with the principles of building international competitiveness in the $21^{\text {st }}$ century that have been created by the most developed economies. An analysis of this transition will allow indicating key conditions for further dynamic development of A-TNCs, and thus identifying the preconditions and prospects for expansion of Asian countries and reinforcing their position in the global economy.

The third chapter presents growing activity of China's enterprises in the field of foreign direct investment (FDI) in global mergers and acquisitions (M\&As) market. This process is enhanced by, among others, the implementation of the 'Go 
Global' strategy, accession to the WTO and the possession of vast foreign exchange reserves that should be invested in different ways. The purpose of this chapter is to assess the geographical and industrial structure of Chinese cross-border mergers and acquisitions (CBM\&As). The study is carried out using social network analysis (SNA) - an interdisciplinary research method.

The fourth chapter is devoted to the energy factors of the development of the Chinese economy. These factors are extremely important when considering the relationship that exists between economic growth and energy demand. This correlation is stable over time, although it may become weaker as a result of improved energy efficiency. The chapter presents the global structure and dynamics of primary energy consumption, with particular emphasis on the role of China in this consumption. Particularly noteworthy is the increased demand for electricity in China, which, being "the most universal form of secondary energy", is an indispensable stimulator of economic development. As a consequence of China's economic development, the high dynamics of energy consumption has resulted in a number of side effects, among which climate change and air pollution play a leading role. A strive to eliminate these effects has forced a change in China's energy-related priorities. In addition to limiting the role of coal, the new priorities include in particular the development of renewable energy sources and nuclear energy, as well as a reduction in the energy intensity of the economy. The purpose of the chapter is to measure the dynamics of China's economic growth using indicators related to energy consumption and to demonstrate the impact of changes in the structure of energy production on the environment and the innovativeness of this economy. This country is the most vivid example of Asian countries' economic expansion, both in business and financial terms.

The fifth chapter is aimed to assess the efficiency of government consumption expenditure in the creation of gross domestic product (GDP) in China. The comparative study for the efficiency of government consumption expenditure in the creation of GDP in China and ASEAN member states requires not only the assessment of the efficiency measures estimated in the frame of data envelopment analysis (DEA), but also the evaluation of a percentage share of government consumption expenditure in GDP and the analysis of a relationship between these variables. The assessment of efficiency in terms of GDP while minimizing government consumption expenditure in China seems to be significance for reviewing changes in the economic growth pattern from investment-led growth to final consumption-led growth, which is one of several objectives established to transform China's economy towards slower but more equitable and sustainable development.

An analysis of the more recent trends in the banking sectors in Asia presented in chapter six indicates how the changing environment (economic slowdown, rise of shadow banking, strict prudential supervision) has affected the profitability of credit institutions in the region. The capability of credit institutions to adapt to the new reality may become an important factor determining the pace of Asia's economic growth in the future. 


\title{
Chapter 1
}

\section{Asian trade and global value chains}

\author{
Aleksandra Nacewska-Twardowska*
}

(iD) https://orcid.org/0000-0002-8074-0361

The turn of the $20^{\text {th }}$ and $21^{\text {st }}$ centuries was a period of enormous changes in world trade, which was caused by many factors. Globalization processes, progressive liberalization, and political changes were the primary stimuli affecting the world's economic development that have indirectly impacted trade. These trends were significant for Asian countries, where they became particularly visible.

The following chapter will indicate the changes that have taken place in the trade of Asian countries ${ }^{1}$ since the mid-90s in the context of their participation in global value chains (GVC). Globalization processes, related in particular to the last wave that resulted in a significant increase in exports of materials and semi-finished products, led to a very rapid increase in trade turnover in the global economy. However, do the traditionally presented trade statistics reflect the actual share of individual countries in trade? The growing importance of international production chains has led to a situation in which individual production components cross borders many times and, as a result, inflate traditional trade statistics. Therefore, an analysis of the role of a given country in the global economy can be more accurate when using data on trade in value added. These data also make it possible to determine the position of individual countries in GVC.

* University of Lodz, Department of International Business and Trade.

1 Countries analyzed: Brunei (BRN), China together with Hong Kong (CHN), Philippines (PHL), India (IND), Indonesia (IDN), Japan (JPN), South Korea (KOR), Cambodia (KHM), Malaysia (MYS), Singapore (SGP), Thailand (THA), Taipei (TWN), Vietnam (VHM). 


\subsection{Globalization, global value chains and value added trade}

Globalization is a comprehensive term, defined differently depending on the context. In economic terms, particular emphasis is placed on the free movement of goods, services, and capital which allows doing business in different countries as if the borders between these countries did not exist. ${ }^{2}$ Globalization is similarly defined by many international organizations indicating that this is a concept 'used to describe an increasing internationalization of markets for goods and services, the means of production, financial systems, competition, corporations, technology and industries [...] giving rise to increased mobility of capital, faster propagation of technological innovations and an increasing interdependency and uniformity of national markets. ${ }^{3}$

Three waves of globalization of the economy can be distinguished in the history of global economic development. ${ }^{4}$ As already mentioned, they are closely connected with the liberalization and internal policy implemented by various countries. The first wave began in the mid-nineteenth century and lasted until the outbreak of the First World War. It was characterized by relatively fast industrial and transport development, which resulted in a significant increase in world trade. The second wave of globalization was associated with the reconstruction of trade after World War II and lasted according to various authors until the end of the 1980s. It was characterized by the division of the world economy into two competing blocks, within which multilateral trade developed. Characteristic for this period was a small share in the world trade of the least developed countries that pursued autarky policy. They did not see the possibility of developing their economies through exports and decided to implement a policy of economic isolation. A different strategy was adopted by the so-called "Asian tigers", which associated their economic development with increased exports. They retained the protectionist approach in importing goods, but at the same time opened their economies

2 A similarly defined term can be found in: G. Gaburro, E.J. O’Boyle [2003], Norms for evaluating economic globalization, "International Journal of Social Economics", vol. 30, (1/2); N.R.F. Al-Rodhan, G. Stoudmann [2006], Definitions of Globalization: A Comprehensive Overview and a Proposed Definition, Program on the Geopolitical Implications of Globalization and Transnational Security 6.1-21; P.V. Nikitin, J.E. Elliott [2000], Freedom and the Market, "The Forum for Social Economics", Fall, pp. 1-16.

3 United Nations [2002], Manual on Statistics of International Trade in Services, Eurostat, IMF, OECD, UN, UNCTAD, WTO, 2002 - Annex II, Glossary, http://unstats.un.org/unsd/publication/ Seriesm/Seriesm_86e.pdf, p. 170 (accessed: 07.08.2019).

4 E. Gostomski, T. Michalski [2017], Czy następuje odwrót od globalizacji?, in: A. Gorynia (ed.), Nowe kraje członkowskie UE wobec procesów globalizacji. Żródła konkurencyjności, Wydział Ekonomiczno-Informatyczny w Wilnie, Uniwersytet w Białymstoku, Vilnius, pp. 42-43. 
to foreign investment. This specific growth model was possible, among others, thanks to the help of the United States. It significantly influenced the development of Asian countries in subsequent years. Third phase of globalization began at the turn of the 1980s and 1990s, along with the dynamic IT and communications revolution with simultaneous political and economic changes taking place in many regions of the world. ${ }^{5}$ It was connected with the liberalization of trade in goods, services, and the movement of capital as well as factors of production. This was fostered by international economic and financial organizations (including WTO, IMF, and World Bank) and many regional integration groups. On one hand, they were admitting new member states, and on the other, they began to pursue an active trade policy in favour of new regional trade agreements (RTAs) and free trade agreements (FTAs).

The division of production into separate stages (fragmentation), which can be implemented independently, in combination with the search for the lowest possible manufacturing costs, resulted in the creation of long production chains. These chains are a process during which technology is combined with materials and work to create goods and services. This process is also extended to the distribution and sale of manufactured goods and services. ${ }^{6}$ Production chains defined this way are merged with the concept of global value chains. With the introduction of the GVC concept, researchers have attempted to unify the respective definitions. ${ }^{7}$ At the beginning of the $21^{\text {st }}$ century, it was agreed that different terms: global commodity chains, value chains, value systems, production networks and value networks describe similar ideas. ${ }^{8}$ According to the World Trade Organization, global production chains are interrelated stages of the production of goods/services that cover two or more countries. Under GVC, the process of combining imported intermediate goods and services with domestic goods and services takes place. Then, manufactured goods and services, as final or semi-finished products, are exported to the next production process or final consumer. ${ }^{9}$

The complexity of production chains means that their analysis is difficult and affects the actual assessment of the participation of individual countries in the global economy. The solution is to study trade relationships between countries

5 M. Rosińska [2008], Procesy globalizacji jako geneza kreowania globalnej przestrzeni gospodarczej, "Acta Universitatis Lodziensis. Folia Geographica Socio-Oeconomica”, vol. 9, p. 17.

6 G. Gereffi, J. Humphrey, T. Sturgeon [2005], The governance of global value chains, "Review of International Political Economy", vol. 12 (1) February, p. 79.

7 T. Sturgeon [2009], From Commodity Chains to Value Chains: Interdisciplinary Theory Building in an Age of Globalization, in: J. Bair (ed.), Frontiers of Commodity Chain Research, Stanford University Press, p. 112.

8 G. Gereffi, J. Humphrey, R. Kaplinsky, T.J. Sturgeon [2001], The Value of Value Chains: Spreading the Gains from Globalisation, "IDS Bulletin", vol. 32 (3), Institute of Development Studies.

9 World Trade Organization [2014], World Trade Report 2014. Trade and development: recent trends and the role of the WTO, Genewa. 
in terms of added value. The concept of value added trade became popular along with the development of GVC at the turn of the $20^{\text {th }}$ and $21^{\text {st }}$ centuries. Value added is the gross value of a given good/service arising during its production, and it is the difference between the gross value and the value of costs incurred (e.g., purchase of semi-finished products). Value added arises in a single enterprise, as well as within a group of entities or a country. In the last case, i.e., in relation to domestic value added, it will be the sum of expenditure incurred in the production process of a given goods/services within the country. Therefore, trade in value added will be the export of domestic value added or import of value added created abroad. ${ }^{10}$ Figure 1.1. presents these relationships.

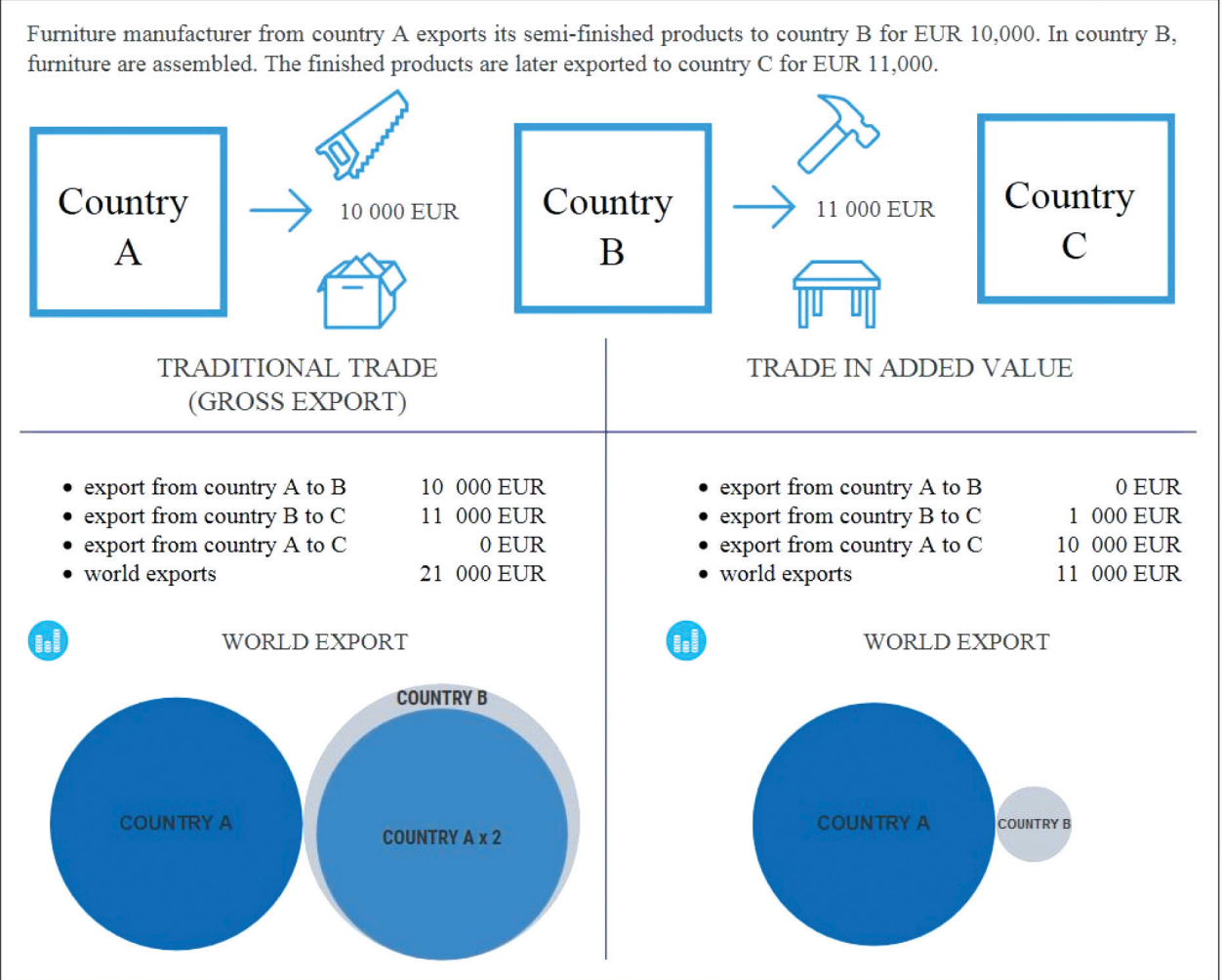

Figure 1.1. Comparison of traditional and value added trade

Source: own elaboration

10 A. Nacewska-Twardowska [2018], Atlas handlu wartościq dodaną. Eksport, Wydawnictwo Uniwersytetu Łódzkiego, pp. 11-15. 
Traditionally, part of the trade is double-counted. As a result, world trade statistics and trade statistics between individual countries do not reflect the actual flows of goods and services:

- in gross terms, country B's exports have been "overstated" 11 times (EUR 11.000 instead of EUR 1.000 in value added);

- this also resulted in an overestimation of total trade by almost half (EUR 10.000) (figure 1.2.);

- in traditional terms of international trade, the export of country A to country $\mathrm{B}$ is invisible.

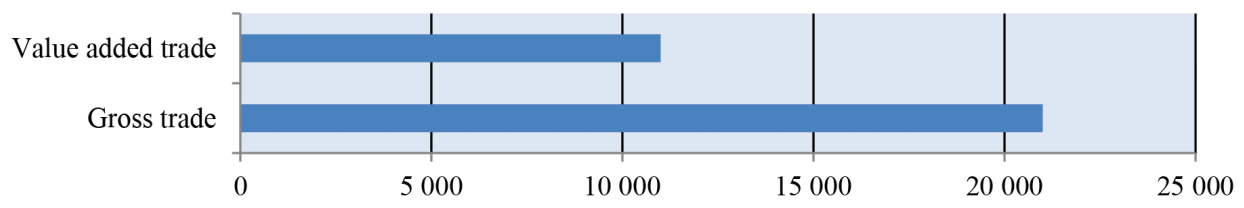

Figure 1.2. Comparison of gross trade statistics and value added trade statistics from figure 1.1. (in EUR)

Source: own elaboration

When analysing world trade using the two methodologies, the differences that appear in the turnover of goods and services in geographical terms are very significant. In the traditional approach, part of the export/import is not recorded (flows between countries $A$ and $C$ from figure 1.1.). When analysing the value added trade, it becomes possible to observe real flows of goods and services between individual countries. This comparison is presented on figure 1.3.

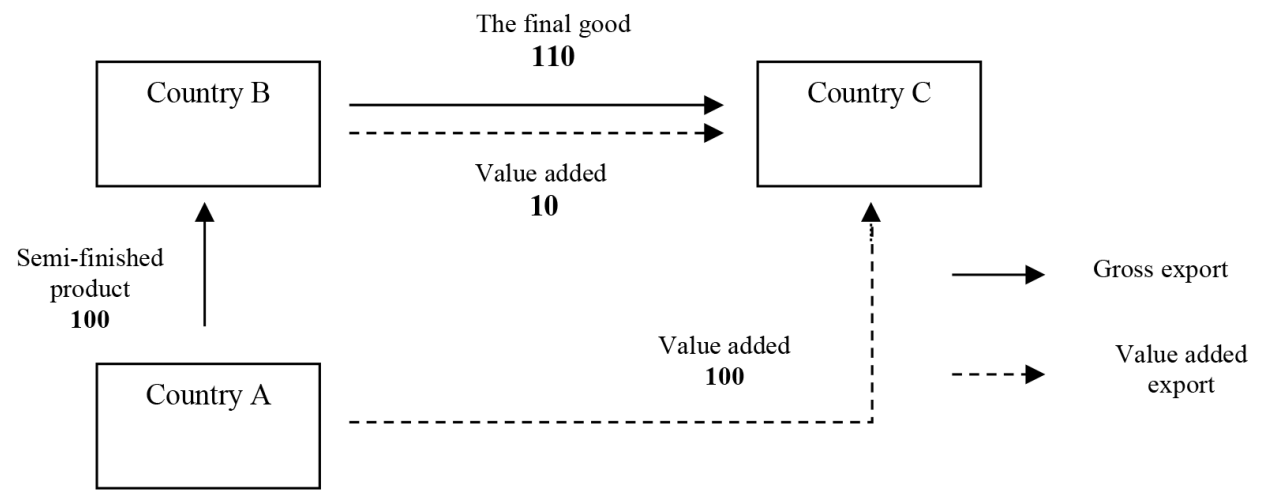

Figure 1.3. Comparison of gross trade and value added trade in a geographical context

Source: own elaboration

From an economic point of view, another significant factor is the analysis of the place that a given economy holds in global value chains. As noted in the early $90 \mathrm{~s}$ by Stan Shih, CEO of Acer, various tasks performed in the production process bring 
different income calculated as added value. Processes associated with manual labour are relatively less profitable than those related to research and development, marketing or distribution. ${ }^{11}$ Shih presented his observations in the form of a 'smile curve' describing the relationship between added value and position in the production chain (figure 1.4.). Both high and low GVC position indicator is associated with high added value.

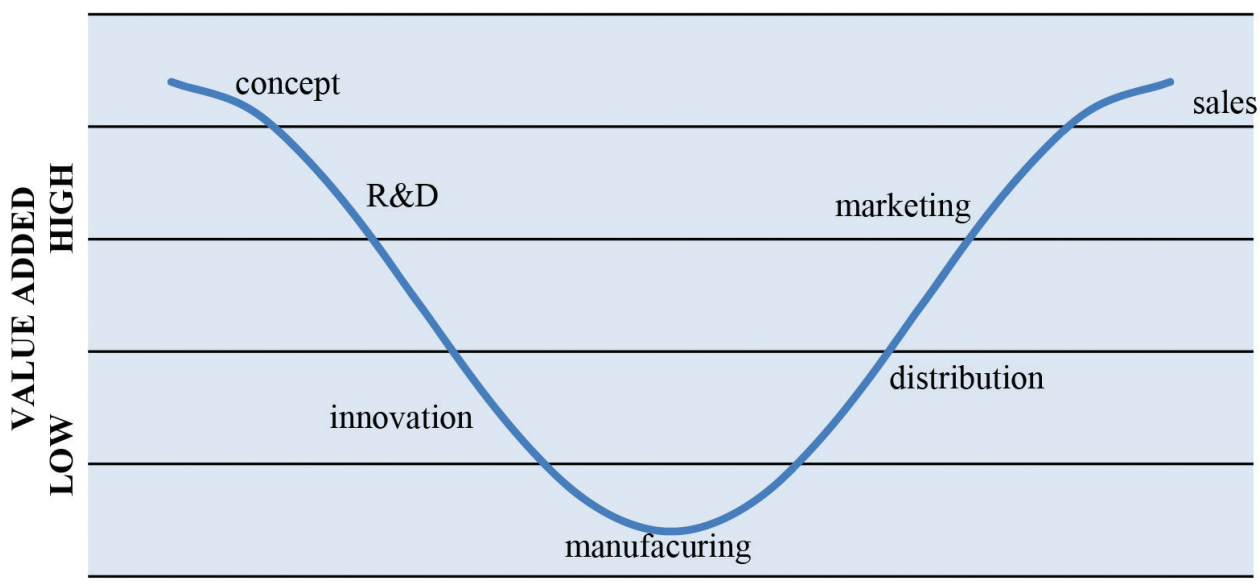

START

\section{GLOBAL PRODUCTION CHAIN}

END

Figure 1.4. Stan Shih's smile curve Source: own elaboration

The analysis of trade exchange in terms of added value allows not only to illustrate real export and import but also allows determining the position of the studied country in the global value chain. This, in turn, makes it possible to calculate the real income (profits) brought about by the participation in the global economy.

\subsection{Statistical data and methodology}

The advantages of conducting trade analyses based on data on value added trade are considerable. However, access to data illustrating the exchange of goods and services in terms of value added is a problem. The first attempts to measure real trade shares

11 K. Kase, A. Slocum, Y. Zhang [2011], Asian versus Western Management Thinking: Its CultureBound Nature, "The Nonaka Series on Knowledge and Innovation", Palgrave Macmillan, UK, p. 169; UNCTAD [2015], Tracing the value added: product-level case studies in China, New York and Geneva, pp. 2-3. 
were made by describing the production chains of individual goods. The best-known examples are Apple products, ${ }^{12}$ Barbie doll ${ }^{13}$ and some computers. ${ }^{14}$ Obtaining data presenting the export and import of value added globally was a huge challenge, and it was necessary to build international input-output tables. The two currently most extensive databases containing such information are WIOD (World Input-Output Database) and TIVA (Trade in Value-Added). The first was created as part of a project funded by the European Commission. Its 2016 edition includes data for EU28 countries and 15 other major economies for the time period 2000-2014 broken down into 56 sectors. The second database was prepared by the WTO and OECD as part of a joint initiative. The 2018 edition contains statistical data on 64 countries (including EU28, G20 countries, most East and Southeast Asian economies, and selected South

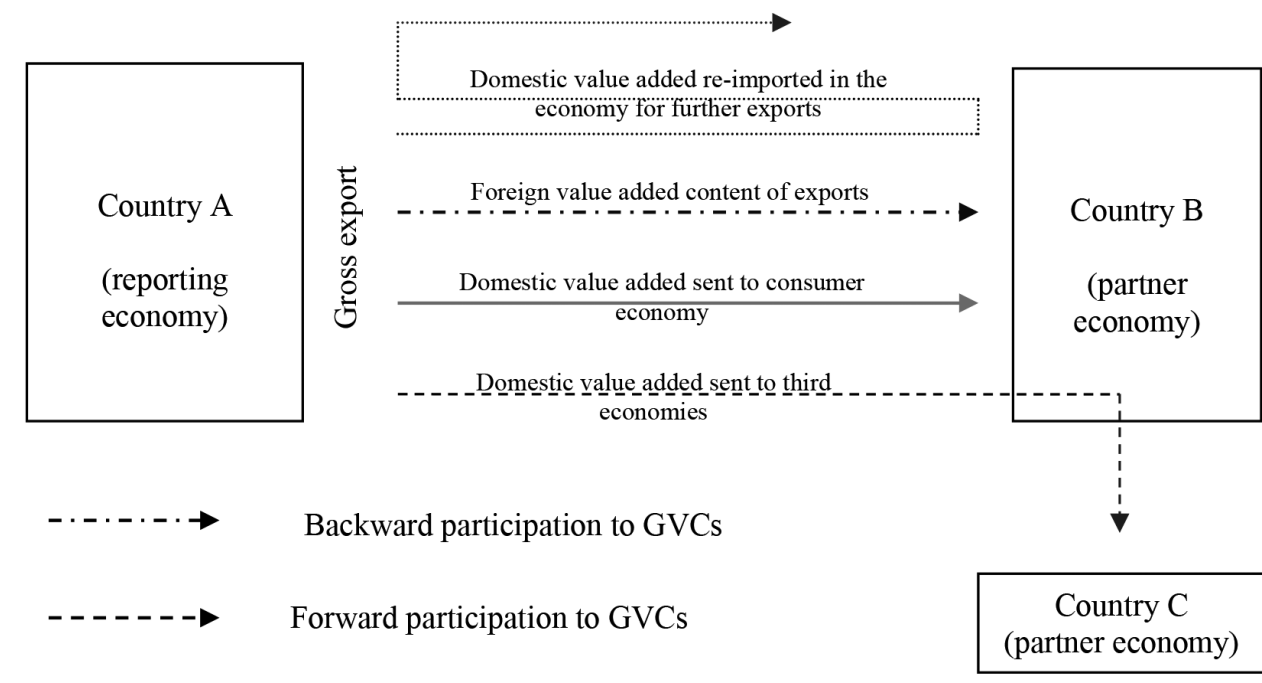

Figure 1.5. Division of gross exports into domestic and foreign value added along with links up and down the supply chain

Source: own elaboration based on: OECD-WTO TiVA Database [2016], Trade in Value-Added and Global Value Chains profiles. Explanatory notes. OECD, http://www.oecd.org/industry/ind/ measuringtradeinvalue-addedanoecdwtojointinitiative.htm (accessed: 22.10.2016)

12 J. Dedrick, K.L. Kraemer, G. Linden [2008], Who Profits from Innovationin Global Value Chains? A Study of the iPod and Notebook PCS, "Industry Studies", 1-2 May, Boston; G. Linden, K.L. Kraemer, J. Dedrick [2009], Who captures value in a global innovation network?: the case of Apple's iPod, "Communications of the ACM", vol. 52, no. 3, pp. 140-144; OECD [2013], Interconnected Economies: Benefiting from global value chains. Synthesis Report, Paris; World Economic Forum [2012], The Shifting Geography of Global Value Chains: Implications for Developing Countries and Trade Policy, Global Agenda Council on the Global Trade System.

13 R. Tempest [1996], Barbie and the World Economy, "Los Angeles Times", 22.10.1996, https:// www.latimes.com/archives/la-xpm-1996-09-22-mn-46610-story.html (accessed: 10.08.2019).

14 J. Dedrick, K.L. Kraemer, G. Linden [2008], op. cit. 
American countries) for the years 2005-2015 broken down into 36 sectors. Data since the mid-1990s are also available. Due to the scope of resources, the TIVA database will be used to present trade-related phenomena in Asian economies.

The above figure 1.5. presents the division of gross exports into domestic and foreign value added along with links up and down the supply chain. By analysing these relationships, a position in GVC can be evaluated. Backward participation relates to links up the supply chain i.e. all goods and services that had to be imported first before they could be exported. Forward participation reflects the links down the supply chain. They are goods and services produced in the country and then exported to third countries. The research methodology, including the analysis of changes in participation and position in global production chains, was prepared based on solutions proposed by Koopman ${ }^{15}$ with others and UNCTAD: ${ }^{16}$

- index of the share of domestic value added in gross exports;

$$
G V C_{D V A \text { participation }}=\frac{D V A}{\text { Export }_{\text {gross }}}
$$

- indexes of participation in the global value chain (3 types):

- GVC backward participation - the share of foreign value added in gross exports, also referred to as the indicator of vertical specialization of the country, is the share of foreign value added in gross exports. It allows to assess 'how important imports are for the exports of a given country' and the higher the ratio, the greater the relationship;

$$
G V C_{\text {backward participation }}=\frac{F V A}{\text { Export }_{\text {gross }}}
$$

- GVC forward participation - the share of the indirect national value added in gross exports is the indirect share of domestic value added in partners' exports, and its size determines the role of value added generated in a given country in exports of other countries;

$$
G V C_{\text {forward participation }}=\frac{I D V A}{\text { Export }_{\text {gross }}}
$$

- general GVC participation index - is the sum of foreign value added in exports and indirect domestic value added in relation to gross exports; the larger this indicator is, the greater the country's share in the global value chain;

15 R. Koopman, W. Powers, Z. Wang, S.J. Wei [2010], Give Credit Where Credit Is Due: Tracing Value Added in Global Production Chains, "NBER Working Paper", vol. 16426.

16 UNCTAD [2013], World Investment Report 2013: Global Value Chains: Investment and Trade for Development, New York and Geneva. 


$$
G V C_{\text {participation }}=\frac{F V A+I D V A}{\text { Export }_{\text {gross }}}
$$

- index for the position in the global value chain determines the difference between backward and forward participation and enables estimation of position in global value chains, thus indicating whether a given country specializes in the first or last stages of production; If the country is in the early stages of the production chain, it is likely to have high forward participation (a positive position index in global value chains); if the backward participation index is quite high, it probably imports a lot of intermediate goods and specializes in the last stages of production (negative position index in global value chains).

$$
G V C_{\text {position }}=\log \left(1+\frac{I D V A}{\text { Export }_{\text {gross }}}\right)-\log \left(1+\frac{F V A}{\text { Export }_{\text {gross }}}\right)
$$

\subsection{Share of Asian economies in international trade}

With the latest wave of globalization, trade in the world has increased significantly in traditional terms (table 1.1.). The world average year-on-year growth rate in the 1990 s was calculated at $6.7 \%$. The next decade was characterized by an average increase of $9.2 \%$, despite the collapse of world trade following the global financial and economic crisis. In subsequent years, the average annual growth rate dropped to $5.52 \%$. At the same time, Asia remained a region in which the average annual export growth rate was higher than for the global economy and exceeded $7 \%$ over the course of the last nine years.

Table 1.1. Average annual increase in gross exports in 1990-2018 (\%)

\begin{tabular}{|l|c|c|c|}
\cline { 2 - 4 } \multicolumn{1}{c|}{} & $\mathbf{1 9 9 0 - 1 9 9 9}$ & $\mathbf{2 0 0 0 - 2 0 0 9}$ & $\mathbf{2 0 1 0 - 2 0 1 8}$ \\
\hline World & 6.70 & 9.20 & 5.52 \\
\hline Africa & 3.65 & 13.75 & 3.73 \\
\hline Asia & 8.15 & 10.54 & 7.25 \\
\hline Australia and New Zealand & 5.15 & 10.36 & 6.63 \\
\hline Europe & 8.76 & 8.52 & 4.37 \\
\hline North America & 7.57 & 5.22 & 5.60 \\
\hline South and Central America & 5.93 & 11.62 & 4.36 \\
\hline
\end{tabular}

Source: own elaboration based on: OECD-WTO TiVA Database [2019], https://stats.oecd.org/ (accessed: 11.08.2019) 
It should be noted that the data from table 1.1. do not present real changes in exports because these can only be illustrated in terms of value added. In addition to changes in the total volume of exports, it is important to check the share of products and services produced in a given economy (share of domestic value added, DVA) in total exports. Figure 1.6. presents data from the mid-1990s for gross exports and value added of selected Asian countries. Over the entire analysed period, a similar trend is noticeable for gross exports and DVA, but smaller fluctuations characterize domestic value added in exports. This means that domestic value added export increases more slowly than traditionally measured exports, but at the same time, its share becomes larger as total exports decline.

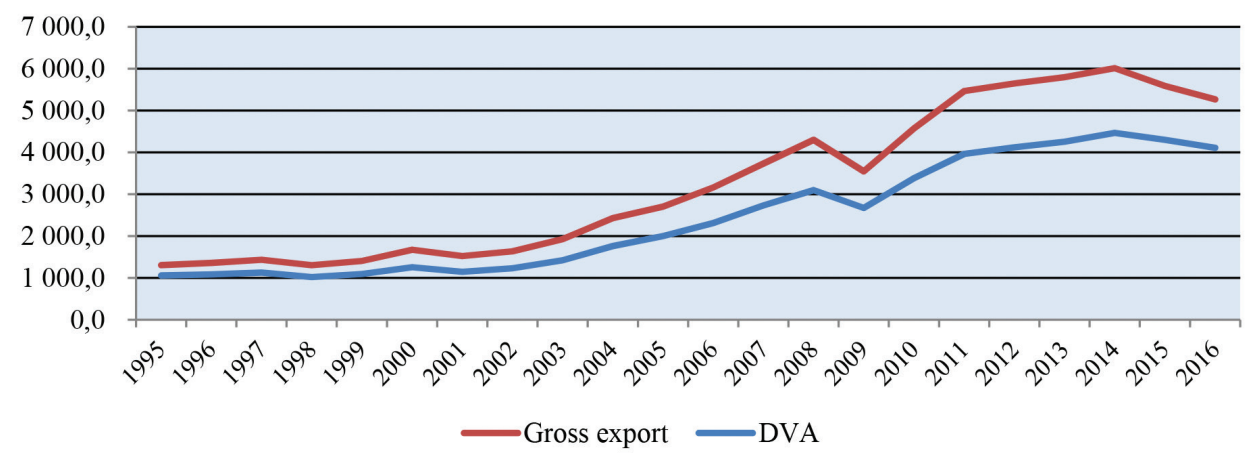

Figure 1.6. Traditional and value added exports (DVA) of selected Asian countries in 1995-2016 (bln USD)

Source: own elaboration based on: OECD-WTO TiVA Database [2019], https://stats.oecd.org/ (accessed: 11.08.2019)

The share of domestic value added in total exports was different for individual Asian countries and was subject to large fluctuations (figure 1.7.). On average, it remained at the level of 0.8-0.7, with the highest values recorded in the mid-1990s. After a decrease, the index began to rise again in the second decade of the $21^{\text {st }}$ century. Above-average rates were recorded in three countries: Brunei, Indonesia, and Japan. On the other hand, the lowest values of the indicator were observed in Singapore, Vietnam, and Malaysia. The latter economy, together with Cambodia, also recorded the most considerable fluctuations in the share of domestic value added in exports. Such dynamic changes over 20 years indicate that Asian countries had to quickly adapt to the rapidly changing conditions of the global economy.

Along with changes in the structure of exports of the analysed countries, there were also changes in the share of individual countries in total exports (table 1.2.). ${ }^{17}$ The studied economies can be divided into three groups. First group includes countries that significantly increased their share in total exports. The most spec-

17 More information in the appendix. 


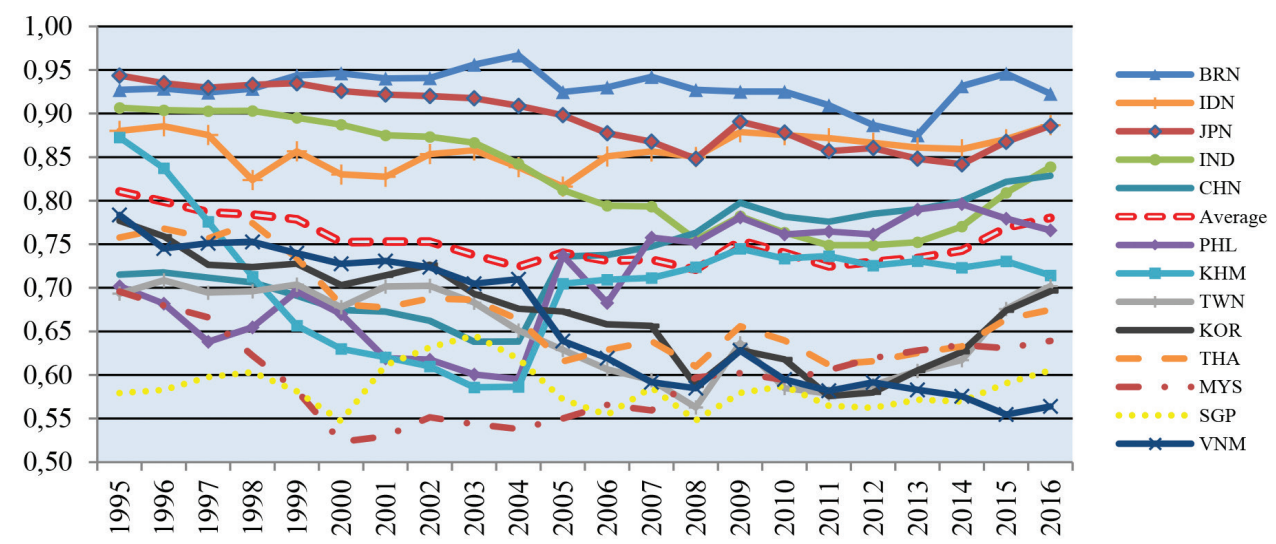

Figure 1.7. Index of the share of domestic value added in gross exports of selected Asian countries in 1995-2016

Source: own elaboration based on: OECD-WTO TiVA Database [2019], https://stats.oecd.org/ (accessed: 11.08.2019)

tacular is the increase in China's share from $15 \%$ to $39 \%$ in gross terms and from $13 \%$ to $42 \%$ in terms of value added. Among other economies in this group, India and Vietnam stand out. The second group of countries includes those whose share in total exports has fallen. Japan recorded the most substantial reduction in the share, from $37 \%$ to $13 \%$ and from $43 \%$ to $15 \%$, respectively. Taiwan is also a country that significantly decreased its share in the years 1995-2016. However, a third group of countries could also be distinguished, including economies which maintained their share in total exports at a similar level for over the 20 years, such as Korea, Thailand, or Malaysia. The differences between the statistical data in the traditional and value-added terms are also interesting. Japan's traditionally measured share of gross exports is underestimated when compared to DVA, while it overestimates the share of South Korea.

Table 1.2. Comparison of the share of selected Asian countries in total exports in 1995 and 2016

\begin{tabular}{|c|c|c|c|c|}
\cline { 2 - 5 } \multicolumn{1}{c|}{} & \multicolumn{2}{c|}{ Gross Export (\%) } & \multicolumn{2}{c|}{ Export of DVA (\%) } \\
\cline { 2 - 5 } & $\mathbf{1 9 9 5}$ & $\mathbf{2 0 1 6}$ & $\mathbf{1 9 9 5}$ & $\mathbf{2 0 1 6}$ \\
\cline { 2 - 5 } & 1 & 2 & 3 & 4 \\
\hline JPN & 37.0 & 13.0 & 43.0 & 15.0 \\
\hline KOR & 12.0 & 11.0 & 11.0 & 10.0 \\
\hline BRN & 0.0 & 0.0 & 0.0 & 0.0 \\
\hline KHM & 0.0 & 0.0 & 0.0 & 0.0 \\
\hline
\end{tabular}


Table 1.2 (cont.)

\begin{tabular}{|c|c|c|c|c|}
\cline { 2 - 5 } \multicolumn{1}{c|}{} & 1 & 2 & 3 & 4 \\
\hline CHN & 15.0 & 39.0 & 13.0 & 42.0 \\
\hline IND & 3.0 & 8.0 & 3.0 & 8.0 \\
\hline IDN & 4.0 & 3.0 & 5.0 & 4.0 \\
\hline MYS & 5.0 & 4.0 & 4.0 & 3.0 \\
\hline PHL & 2.0 & 2.0 & 2.0 & 1.0 \\
\hline SGP & 7.0 & 6.0 & 5.0 & 4.0 \\
\hline TWN & 9.0 & 6.0 & 8.0 & 5.0 \\
\hline THA & 5.0 & 5.0 & 5.0 & 4.0 \\
\hline VNM & 1.0 & 3.0 & 1.0 & 2.0 \\
\hline
\end{tabular}

Source: own elaboration based on: OECD-WTO TiVA Database [2019], https://stats.oecd.org/ (accessed: 11.08.2019)

In 2016, the analysed countries participated to different degrees in global value chains (figure 1.8.). China, Vietnam, and Malaysia had the largest share, where about $65 \%$ of exports related to GVC. The country with the smallest share of under $20 \%$ was Brunei. At the same time, individual economies were characterized by a varying level of position index in global value chains. China, Japan, Indonesia, and India were relatively high with substantial forward participation. Therefore,

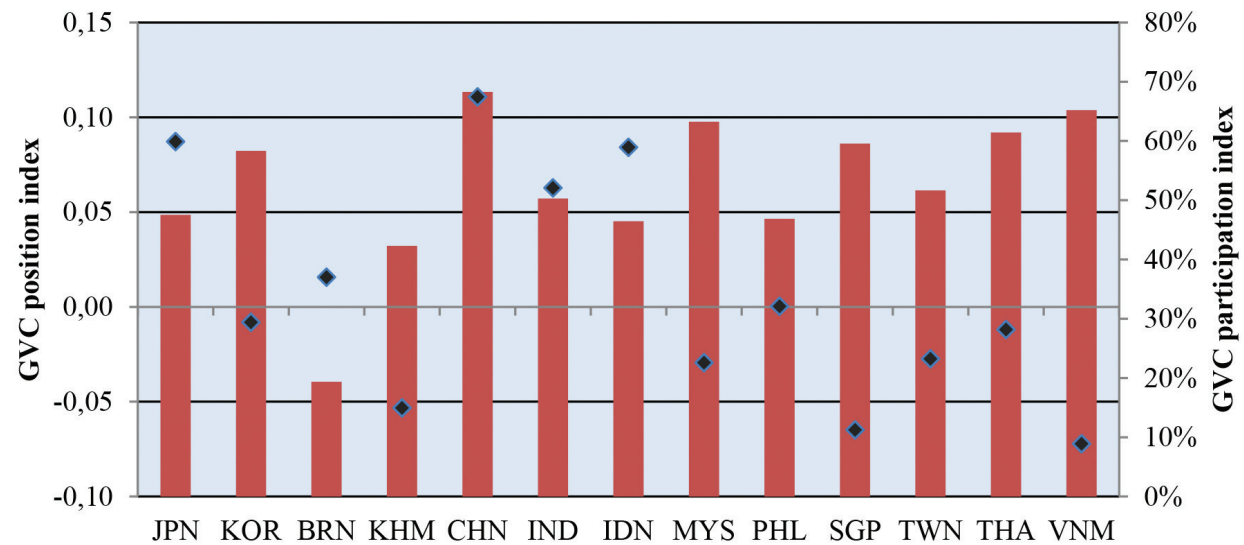

Figure 1.8. General index of participation in the global value chain and position index in the global value chains of selected Asian countries in 2016

Source: own elaboration based on: OECD-WTO TiVA Database [2019], https://stats.oecd.org/ (accessed: 11.08.2019) 
they are countries that export a lot of intermediate products or services used in subsequent production stages in other countries. On the other side were Vietnam, Singapore, and Cambodia, with a relatively high backward participation index. These are the countries that import more intermediate goods and specialize in the last stages of production.

\subsection{Analysis of the largest Asian economies}

The three largest Asian economies in terms of exports, measured both traditionally and in terms of value added, are China, Japan, and South Korea. Korea and China have significantly increased their exports since the mid-1990s. In these countries it increased almost four- and tenfold respectively. Japan was a country that, although experienced an over $46 \%$ increase in gross export (37\% in domestic value added export), at the same time recorded the largest decrease in the share of total exports. A detailed analysis of changes in the share of these three countries in global value chains is presented in the sections below.

\section{China}

Between the years 1995 and 2016, two periods can be distinguished during which the indices of participation in global value chains were characterized by different trends (figure 1.9.). Until the middle of the first decade of the $21^{\text {st }}$ century,

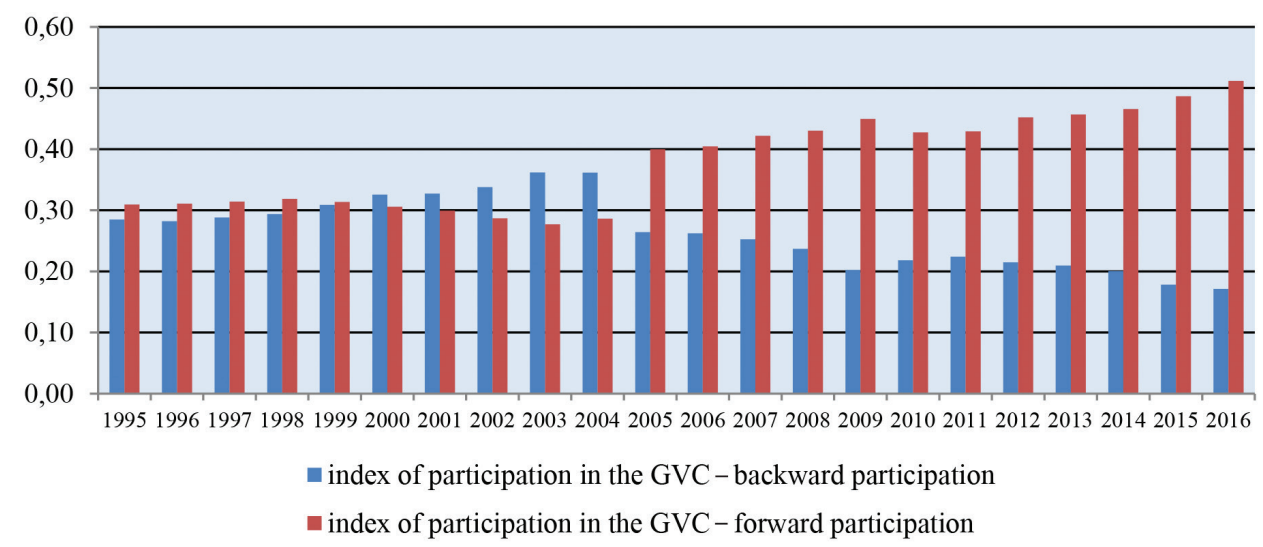

Figure 1.9. China's backward and forward participation in the GVC in 1995-2016 Source: own elaboration based on: OECD-WTO TiVA Database [2019], https://stats.oecd.org/ (accessed: 11.08.2019) 
backward and forward participation was at a similar level, with the first one showing a slight upward trend and the second a downward trend. These trends changed after 2004 when forward participation in the GVC began to significantly outperform backward participation.

The effect of these changes is visible in the rapid shift in position in global value chains (figure 1.10.). This indicates an increase in exports of products and services that are used in the next stages of production in other countries to be subsequently exported to third partners. At the same time, China's overall share in global value chains is quite stable, with a visible upward trend.

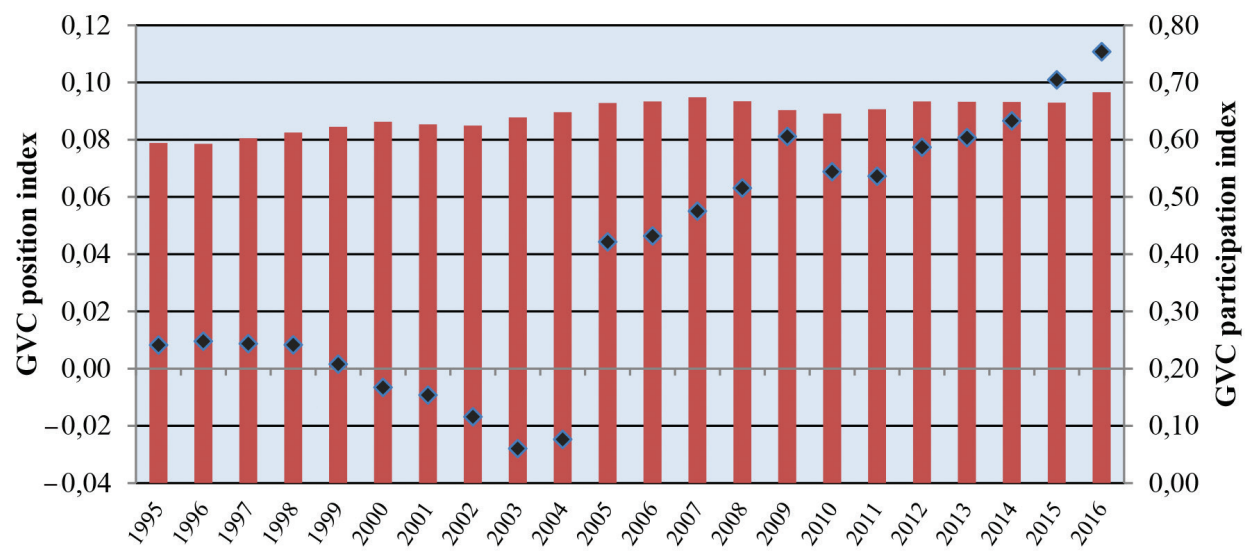

Figure 1.10. General indexes of participation and position in the global value chains of China in 1995-2016

Source: own elaboration based on: OECD-WTO TiVA Database [2019], https://stats.oecd.org/ (accessed: 11.08.2019)

\section{South Korea}

From the mid-1990s to 2011/2012, the GVC participation index related to backward participation in Korea was on the rise (figure 1.11.). At the same time, frontal participation showed a downward trend. In subsequent years, these trends reversed and, as a result, share indices were evened out.

The overall GVC share index for South Korea (figure 1.12.) fluctuated around $60 \%$ in during the analysed period. The highest values, above the mentioned average, were recorded in 2008-2014. The downward trend in Korea's position in global value chains reversed after 2012, when the backward participation index began to decline. For the Korean economy, this may be an unfavourable trend, suggesting that it is in the middle of the smile curve, thus bringing the lowest benefits from international trade. 


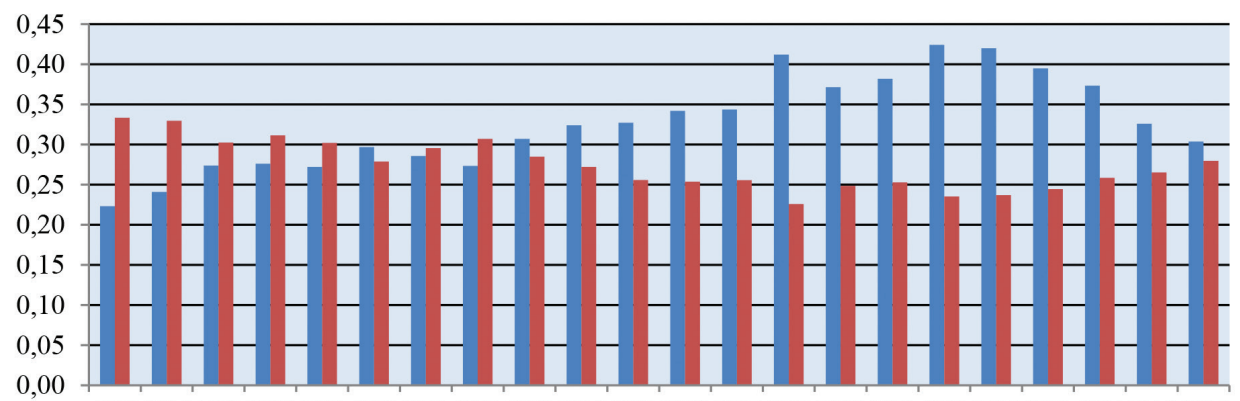

घ index of participation in the GVC - backward participation

- index of participation in the GVC - forward participation

Figure 1.11. Backward and forward participation of South Korea in GVC in 1995-2016

Source: own elaboration based on: OECD-WTO TiVA Database [2019],

https://stats.oecd.org/ (accessed: 11.08.2019)

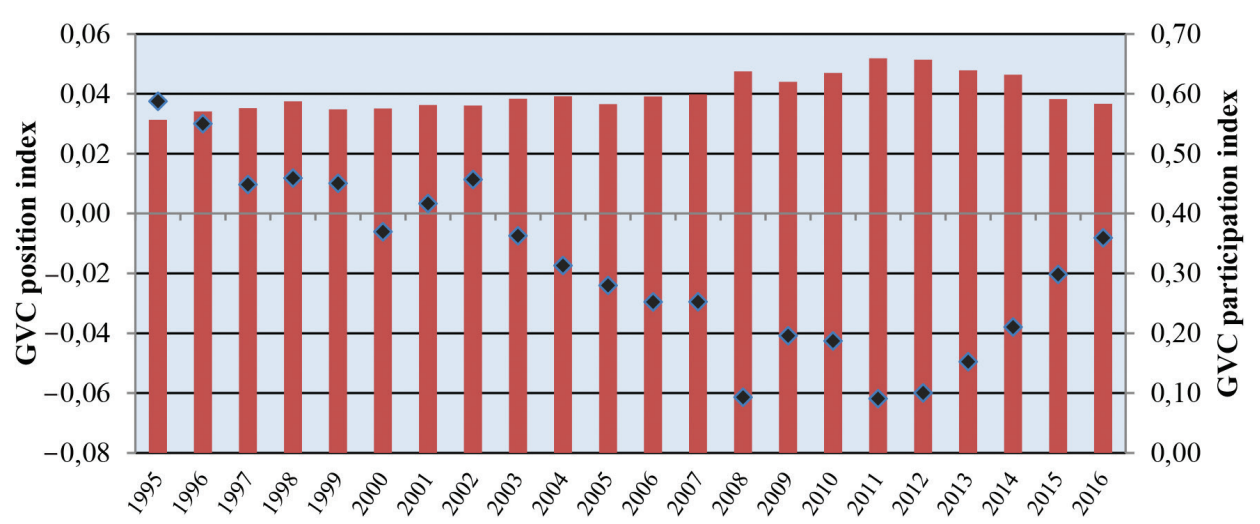

Figure 1.12. General indexes of participation and position in the global value chains of South Korea in 1995-2016

Source: own elaboration based on: OECD-WTO TiVA Database [2019], https://stats.oecd.org/ (accessed: 11.08.2019)

\section{Japan}

Next figure (1.13.) presents Japan's share in global value chains - participation indices in GVC were quite stable. The level of forward participation was significantly higher in the entire analysed period than backward participation, although the latter increased after 2005. The consequence of this was the decline in the position of the Japanese economy in global value chains, although the overall GVC participation index did not change significantly (figure 1.14.). 


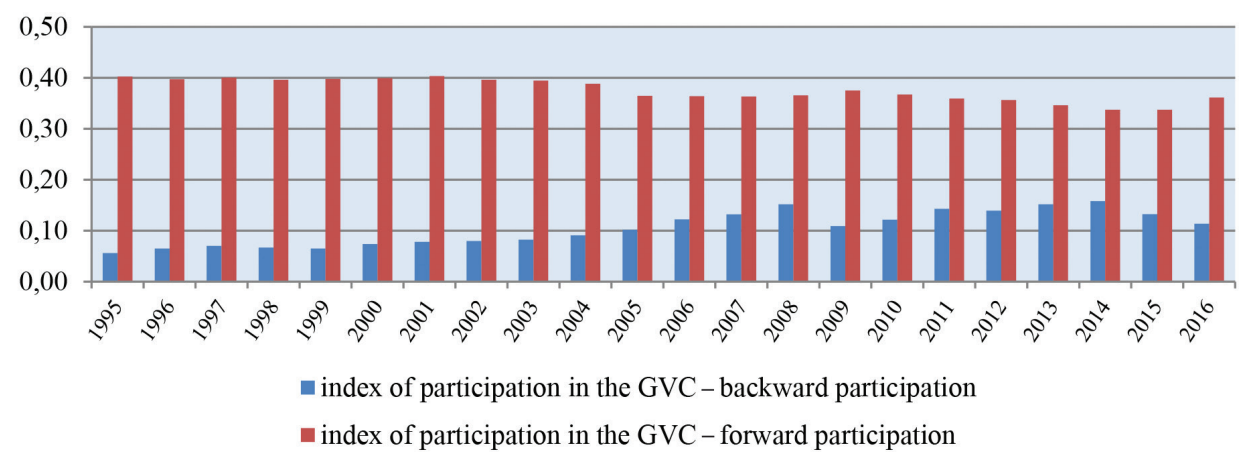

Figure 1.13. Japan's backward and forward participation in the GVC in 1995-2016 Source: own elaboration based on: OECD-WTO TiVA Database [2019], https://stats.oecd.org/ (accessed: 11.08.2019)

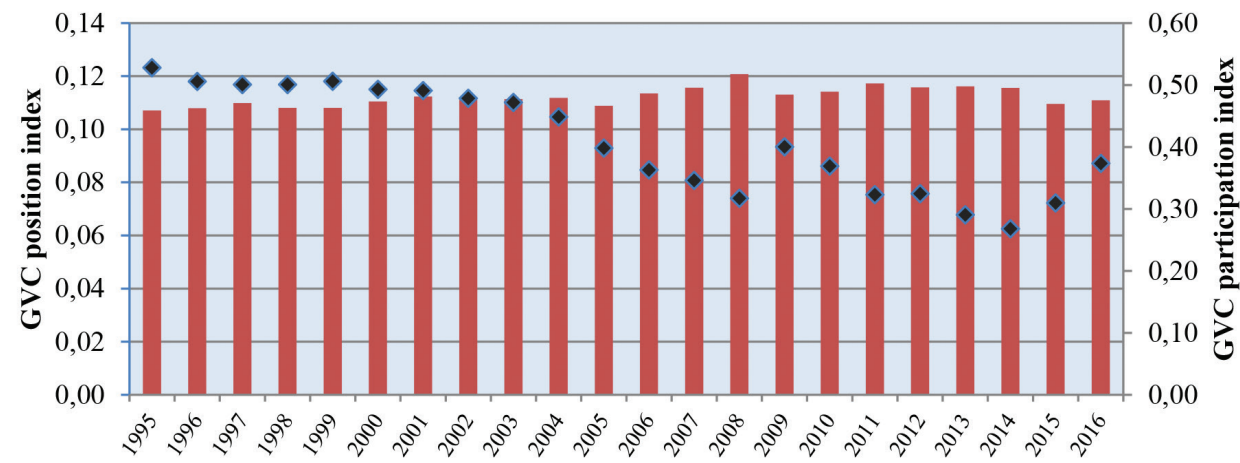

Figure 1.14. General indexes of participation and position in the global value chains of Japan in 1995-2016

Source: own elaboration based on: OECD-WTO TiVA Database [2019], https://stats.oecd.org/ (accessed: 11.08.2019)

\section{Conclusions}

Changes in the global economy have affected most of the world's economies. United States and developed Western European countries have experienced a reduction in their share of global trade. At the same time, the increase in GDP, higher than the average global GDP growth, and the average annual increase in exports in Asian countries caused the region to strengthen their economic position. However, these processes differed in individual Asian countries. On the one hand, China should be indicated as a country whose export share has increased tenfold. On the other hand, at the same time, the largest Asian economy in the second half 
of the $20^{\text {th }}$ century, Japan, recorded a slowdown and fell to the second position in exports among the analysed countries. Comparison of trade data in the traditional and value added terms showed that in some cases, exports were underestimated and in some cases overestimated. This was the effect of a much higher index of participation in the global value chain related to forward participation. Therefore, when changes in exports were associated with an increase in exports of products or services that were used in further production and exports by third countries, gross export was usually underestimated in relation to domestic value added export. Differences between backward and forward participation meant that the position of individual countries in the GVC changed. In some cases, when the position index was relatively high (e.g., China) or low (e.g., Singapore), this indicated a relatively high share of domestic value added in exports (2016). However, a broader analysis might be necessary because e.g. in Japan the GVC position index was quite high in 2016, but it was preceded by a downward trend, suggesting unfavourable changes in Japanese exports over the analysed period.

Trade analyses using added value data enable in-depth research into changes in the global economy. They allow not only to assess the participation of individual countries in exports, but also help to assess the changes that occur in the context of participation in global value chains. The share of Asian countries in the global economy increased significantly during the period between the years 1995 and 2015, which is mainly associated with a growing share in the GVC. Most of the studied countries have become foremost suppliers of semi-finished products on the one hand and are used for manufacturing purposes on the other. Conclusions of chapter 1 are connected with the changes that have taken place in the largest Asian transnational corporations. This issue is elaborated on further in the next chapter of the book. 


\section{Appendix}

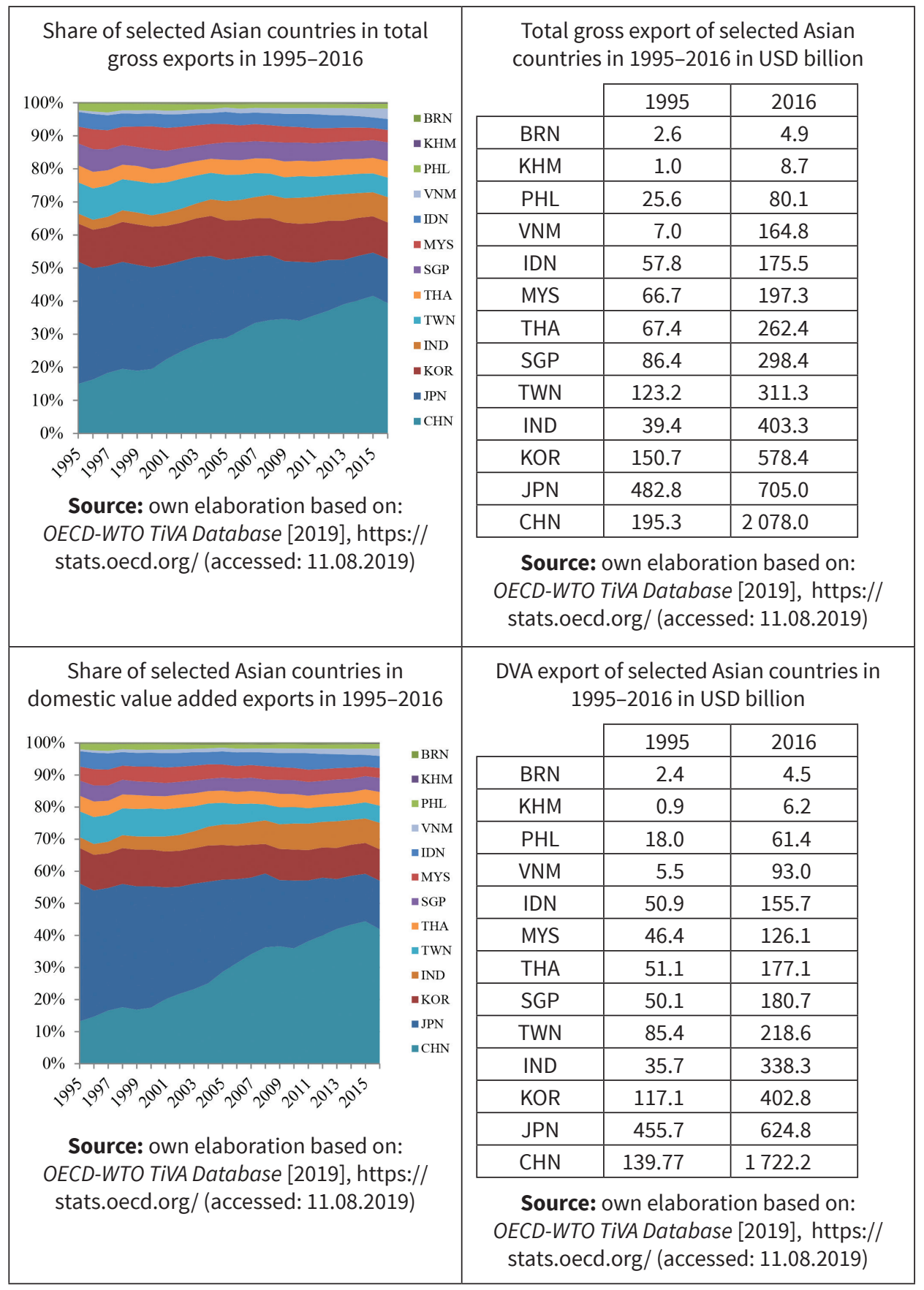




\title{
Chapter 2
}

\section{The most powerful Asian transnational corporations}

\author{
Magdalena Rosińska-Bukowska* \\ (iD) https://orcid.org/0000-0003-4525-0751
}

The chapter attempts to assess the development determinants and prospects of Asian transnational corporations while taking into account the requirements of building competitiveness in the modern global economy. The chapter has been divided into five subchapters.

The first one outlines the changes that have been taking place in the modern economy and their consequences in building competitiveness of a transnational corporation. The second subchapter focuses on the attributes of transnational corporations (TNCs) which determine the development potential of the most powerful transnational corporations (Top-TNCs). The chapter emphasizes the significance of the integrated influence of attributes in the exploration of the multi-layer capital of the corporate system. The third subchapter describes the essence of the systembased nature of a modern corporation capital, indicating the necessity of using appropriate methods of assessing the development determinants and prospects of Top-TNCs.

The fourth subchapter positions the Asian Top-TNCs against the leading global corporations. The study incorporates the analysis of their positions in the following international rankings: The Forbes Global 2000, The World Investment Report, The 100 Top Brands. The subsequent subchapter presents the assessment of their development potential using two synthetic indicators: the author's indicator of the ability to create added value and the 9-parameter MAC measure created for The World's Most Admired Companies ranking. The chapter ends with conclusions

* University of Lodz, Department of International Business and Trade. 
drawn from the research conducted for the period 2006-2018, determining the top 10 non-financial Asian corporations and the positions of corporations of the Asian Emerging Markets Economies (the A-EMEs). ${ }^{1}$

\subsection{The determinants of building international competitiveness in the $21^{\text {st }}$ century - implications for the assessment of development potential of corporations}

The $21^{\text {st }}$ century brought a radical change in the determinants of building international competitiveness. Currently, its key challenge includes the exploration of the knowledge capital of the whole multi-layer structure of a given organization, or the use of the resources collected on various levels and their simultaneous development (exploration).

The analyses of the pillars of strategies of the most powerful corporations indicate ${ }^{2}$ that the most dynamically developing agents put much pressure on the role of knowledge and innovation (theory of innovation, key competences, behavioural concepts). They also treat the diversity of the global environment as a source of possible advantages, making use of its potential through a systematic increase of internationalization in a business (theory of international production, foreign direct investment theory).

However, what appears to be the most important is the introduction of the following qualities into the management model: the understanding of the essence of coopetition, ${ }^{3}$ glocalization ${ }^{4}$ and orchestration ${ }^{5}$ in order to build adequate relations

1 A-EMES include: China with Hong Kong, India, Indonesia, Korea, Malaysia, Pakistan, the Philippines, Taiwan, Thailand. MSCI World Quality Index [2019], https://www.msci.com/ documents/10199/ (accessed: 30.09.2019). The research included corporations from A-EMEs and additionally TNCs from: Japan, Singapore.

2 M. Rosińska-Bukowska [2012], Rozwój globalnych sieci biznesowych jako strategia konkurencyjna korporacji transnarodowych, Wydawnictwo Uniwersytetu Łódzkiego, Łódź.

3 P. Ritala, A. Golnam, A. Wegmann [2014], Coopetition-based business models: The case of Amazon.com., „Industrial Marketing Management”, vol. 43, pp. 236-249; P. Klimas [2015], Structural Face of Competition, Cooperation and Coopetition Inside Business Networks, "Argumenta Oeconomica", vol. 1 (34), pp. 127-155; Y.D. Lou [2005], Toward Coopetition within a Multinational Enterprise: A Perspective from Foreign Subsidiaries, „Journal of World Business”, vol. 40 (1), pp. 71-90.

4 V. Roudometof [2016], Theorizing glocalization: Three interpretations, "European Journal of Social Theory", vol. 19 (3), pp. 391-408.

5 P. Hurmelinna-Laukkanen, S. Nätti [2018], Orchestrator types, roles and capabilities - A framework for innovation networks, "Industrial Marketing Management", vol. 74. 
and structures (theories of: agglomeration, mergers and acquisitions, organization and management). That signifies the necessity to abandon traditional competition based on market strength and dominance of a single agent. What is, instead, required is the creation of connections that improve innovation, the refinement of learning procedures, the search for new methods of implementing skills and the adaptation of organization methods and forms as well as management structures to fit the dynamic changes occurring within the corporation.

In the modern model of building the competitiveness of Top-TNCs, the exploration of knowledge resources of an organization as a whole is of fundamental significance. In this model, the development potential is based on combining opposites - cooperation and competition (coopetition); localization and globalness (glocalization); standardization and adaptation (interculturalism). Putting pressure on qualitative changes regarding both processes and products, particularly the quality of interaction infrastructure, is indispensable. Regular modifications to the mechanism of system coordination and regulation aim to improve the transfer of knowledge from all types of stakeholders. To maintain a balanced, long-term development of a corporation, the system control mechanism must involve the participation of all stakeholders.

Taking into account these requirements demands a 4C systemic approach, based on comprehensiveness, corporateness, congruence and creativity. Comprehensiveness is a holistic approach to fulfil tasks. Corporateness is the ability to build all-level permanent coalitions, the immanent features of which must include the possibility to coexist. As a consequence, the system responsible for the effective building of international competitiveness in the $21^{\text {st }}$ century must be based on congruence, ensuring a harmonious coexistence with a multicultural global environment and a multitude of stakeholder groups. Creativity is a paradigm pillar of the international competitiveness of corporations ${ }^{6}$ perceived as such, understood as combining skills and key competences, innovativeness and social responsibility, diversity of organization forms and cultural dissimilarities into a single changeinspiring system, the aim of which is to obtain the effect of synergy. The measure of system effectiveness is the ability to create added value, understand the ideas of social and economic values and co-create values. ${ }^{7}$

Since the above-mentioned principles have been considered fundamental in the $21^{\text {st }}$ century, it is necessary to take another look at the capital of corporations as a system enabling continual adjustments, an immanent feature of which is change itself. Meeting these requirements is possible thanks to the appropriate structure of the

6 M. Rosińska-Bukowska [2016], The Model of Competitiveness Assessment of Coopetition Network Systems - Competition and Cooperation of Enterprises in the Global Economy, "Journal of Economics and Management", vol. 24 (2), pp. 5-13.

7 G. Johnson, K. Scholes [1999], Exploring Corporate Strategy, Prentice Hall Europe, London, pp. 215-217; M.E. Porter, M.R. Kramer [2011], The Big Idea: Creating Shared Value, "Harvard Business Review", vol. 89 (1-2), pp. 62-77. 
system of resources and the modifications to the concept of managing them. In this aspect, understanding the essence of the systemic model of corporation resources and the holistic concept of managing a corporation is crucial. Taking into account the fact that the requirement of long-term competitiveness in the $21^{\text {st }}$ century is a skilful exploration of intellectual capital which, in turn, helps increasing economic capital, the assessment based solely on purely economic parameters does not provide a full image of an agent's development abilities in a dynamically-changing economy.

TNCs have always built their power by adjusting their structures and functioning principles accordingly to the challenges arising in the environment. They have the ability to benefit from the differences in the distribution of the production factors (natural resources, capital, work) and the specificity of policies of individual countries. A corporation's success is largely based on its ability to find its own development concept on the basis of its attributes, or an effective composition of the necessary qualities in each of the layers of the accumulated capital.

In order to depict the methods of implementing the principles of building international competitiveness by Top-TNCs, both a system of attributes determining their development potential and its role as a mechanism transmitting environmental impulses have been presented. Further on a description of the layers of corporation capital, divided into five subsystems - two that encompass economic capital and three presenting intellectual capital - has been provided, depicting them as a foundation of resources enabling the fulfilment of the $4 \mathrm{C}$ systemic approach. As a result it has been emphasized that the areas of analyses necessary to obtain a comprehensive picture of a corporation's development determinants and prospects must be expanded by referring to parameters such as, for instance: social responsibility, innovativeness, management of human resources, creation of sales value on the basis of intangible assets, range of internationalization (assets, employment), quality of products/services and global competitiveness.

\subsection{System of corporation attributes as the foundation of development potential}

A classic definition of "transnational corporations" (TNCs) indicates that these agents manage a globally-organized production and service network and control major economic areas through capital commitment. A dynamic increase in the number of such agents has begun in the mid-1970s. ${ }^{8}$ Since then, corporations have undergone major changes.

8 M. Rosińska-Bukowska [2017], Strategic changes in transnational corporation as an adjustment to the challenges of the $21^{\text {st }}$ Century, "Entrepreneurial Business and Economics Review", vol. 5 (2), pp. 143-157. 
When differentiating between TNCs and traditional corporations, it is crucial not only to accentuate the organizational complexity of an agent, but also the specificity of corporate identity based on coopetition, orchestration and glocalization. The ability to implement the 4C systemic approach (comprehensiveness, corporateness, congruence, creativity) is a real challenge for the most powerful modern corporations (Top-TNCs), enabling a long-term ability to create added value and making it possible to shape social and economic values.

The essence of TNC development comes down to their specific philosophies of expansion. Their strength is the result of their ability to adapt to the changing environment thanks to the abilities of integration and coordination of diverse, globally dispersed activities, taking into account the knowledge capital of the system created. Modern TNCs begin to abandon centralization, specialization and standardization and replace them with diversity, flexibility and creative approach to challenges. ${ }^{9}$ As a result, the developed mechanism transmitting the impulses of the dynamically changing environment is of crucial significance to the efficiency and long-term competitiveness. This system incorporates the intertwining qualities of a given agent that determine its development potential - the attributes of TNCs. For the purposes of this work, it is crucial to understand the essence of interactions between these attributes and their inseparable nature as a single foundation determining development potential. These attributes, ${ }^{10}$ as a system of connected vessels, create an agent's ability to explore a multi-layer corporate system (figure 2.1.).

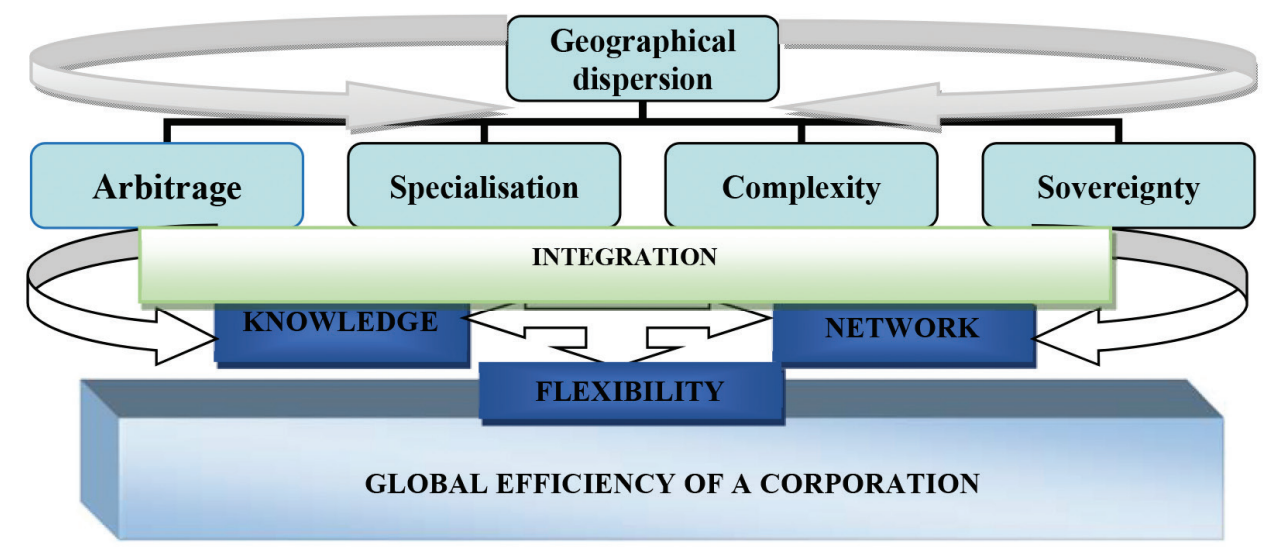

Figure 2.1. The system of the attributes of transnational corporations

Source: own elaboration

9 A. Toffler [1985], Trzecia Fala, PIW, Warszawa, pp. 15-35.

10 Attributes of TNCs: global efficiency, geographical dispersion, arbitration, complexity, specialization, integration, knowledge, networks, flexibility, sovereignty. 
At present, the essence of a corporation's development capital is not only the ability to transfer capital, but the distribution of its resultant knowledge (technology, qualifications, organization, management and marketing methods) outside of the TNC's home country. ${ }^{11}$ Therefore, it is not resource ownership that is the crucial aspect, but the ability to act systemically, that is organize, integrate and efficiently coordinate actions of various units in the process of fulfilling the adopted development strategy, which aims to create added value. ${ }^{12}$ The system of attributes, which acts as a structure of connected vessels, ensures a TNC's effective transfer of skills, production capabilities, competences, capital, brands, marketing concepts as well as organizational and management formulas. It makes it possible for corporations to explore tangible and intangible assets. This is how corporations implement the instructions of the Business Performance Management (BPM) concept, ${ }^{13}$ the modern version of which ${ }^{14}$ relates to the management of the whole organization and emphasizes the necessity to determine the subsequent action stages (purposes), by indicating the requirement of adjusting competences to the evolving purposes in order to obtain satisfactory results.

Therefore, the unique resources of TNCs are created during the interactions within the organization system and on the borders between the agent and its environment. The resources of the corporate system are created, divided, transferred, adapted and changed in order to maintain competitiveness in a dynamic environment. The fundamental determinants of a corporation's development include market structure, participant actions, their network of relationships and the effects of their cumulative influence. In the $21^{\text {st }}$ century, the pillars of Top-TNC development are coopetition, orchestration, glocalization and congruence. As a consequence, the study assessing the position and developmental prospects of Top-TNCs must refer to all layers that make up an organization's capital, including both tangible and intangible assets of the system.

11 M. Wilkins [1998], Multinational Corporations. An Historical Account, in: R. Kozul-Wright, R. Rowthorn (eds.), Transnational Corporations and the World Economy, Wider-McMillan Press-St. Martin's Press, London-New York, pp. 6-95.

12 P. Dicken [2007], Global Shift: Mapping the Changing Contours of the World Economy, Sage Publications Ltd, London.

13 M. Beer, R.A. Ruth [1976], Employee Growth Through Performance Management, "Harvard Business Review", July-August, pp. 59-66; I.B. Pugna, F. Albescu, D. Babeanu [2009], The Role of Business Intelligence in Business Performance Management, "Annals of the University of Oradea, Economic Science Series", vol. 18 (4).

14 In their primary form, the concept by Beer and Ruth concerned staff management and was not systemic in nature. 


\subsection{Systemic nature of corporation capital - layers, parameters, potential assessments}

Capital is a specific economic category capable of both increasing and relying on the collected resources, used not only to attain goals, but also to develop a given agent's business. ${ }^{15} \mathrm{An}$ immanent feature of capital perceived as such is its systemic nature, which means that the layers of capital are a system of connected vessels. This system, as a whole, is responsible for increasing prosperity as well as a stable and long-term development of the corporation.

This work focuses on the role of individual layers of corporation capital in the cocreation of added value. The presented model of its division encompasses the classic foundation of economic capital - market and financial capitals - and takes up the challenge of providing a holistic description of the categories of intellectual capital that determine the efficiency of TNC's actions. Corporation capital can be divided into five subsystems described as follows:

- market capital - coordination of the allocation of rare resources during the production and sales of goods and services; reflects possible combinations of their most efficient use in a given moment - global production systems;

- financial capital - flows of the financial capital; responsible for maintaining the agent's financial liquidity (both current and long-term);

- innovation capital - source of modern solutions and innovative techniques in the production process; the analysis of the expenditure for research and development and the number of new projects generated; providing the possibility of improving individual offers (products and operations), especially regarding key competences;

- organizational capital - systematic modifications of the global chain of the creation of added value, due to the creation of paths of structural adjustments; making use of the opportunities provided by the international environment; exchange of labour resources (quantitative perspective) into human capital that generates added value (qualitative perspective);

- institutional capital - includes norms, habits, institutions that determine the value systems of a given civilization circle, country, region, society, etc.; responsible for skilfully meeting the requirements of multi-institutional global environment and the ability to creatively utilize its potential.

Human capital is purposefully considered not a part of intellectual capital, but a factor that permeates and dynamizes the whole system. Human capital is an indispensable factor that bonds the whole organization together. Therefore, it should not be treated as a separate subsystem, but an immanent superior feature, without which the functioning of both the whole corporation and each of its individual

15 P.L. Bernstein [2007], Capital Ideas Evolving, John Wiley \& Sons, Inc., Hoboken, New Jersey, p. 23. 
parts would be impossible. In the table 2.1. are presented the elements constituting core components of each of the five layers that make up corporation capital (the role of human capital is visible in each of them).

Table 2.1. Corporate capital system

\begin{tabular}{|c|c|c|c|}
\hline Layer & Subject of research & $\begin{array}{c}\text { Concept of the assessment } \\
\text { of a given category }\end{array}$ & \\
\hline 1 & 2 & 3 & \\
\hline 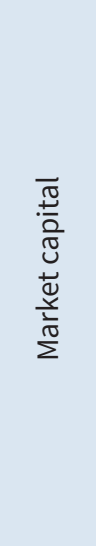 & $\begin{array}{l}\text { Market activity: } \\
\text { assets, sales, employment, profits }\end{array}$ & 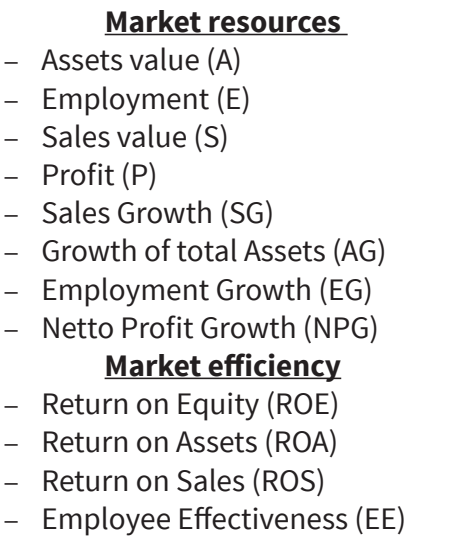 & 络 \\
\hline 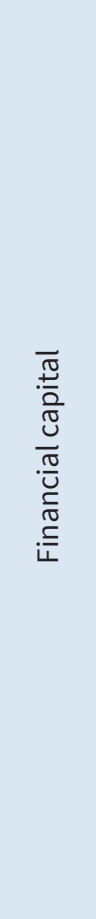 & $\begin{array}{l}\text { Financial flows: accounting } \\
\text { equation; long-term and current } \\
\text { financial status }\end{array}$ & 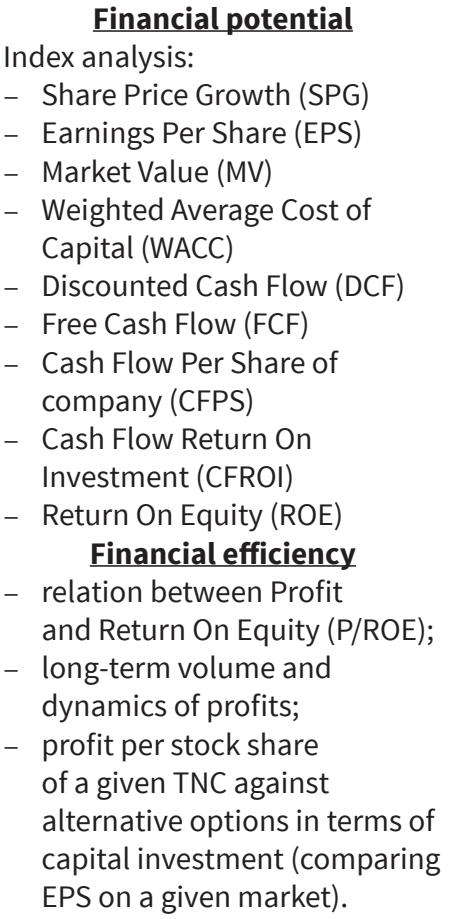 & 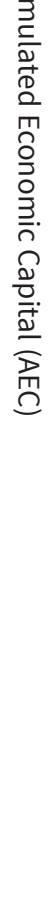 \\
\hline
\end{tabular}




\begin{tabular}{|c|c|c|c|}
\hline 1 & 2 & 3 & \\
\hline 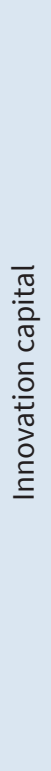 & $\begin{array}{l}\text { Potential for innovation: } \\
\text { research and development } \\
\text { foundation }\end{array}$ & $\begin{array}{l}\text { Innovation } \\
\text { - R\&D investments: profitability } \\
\text { of R\&D expenditures; } \\
\text { relationship between asset } \\
\text { productivity (S/A) and the } \\
\text { dynamics of expenditures for } \\
\text { R\&D; expenditures for the R\&D } \\
\text { zone per single employee; } \\
\text { - position in innovation } \\
\text { rankings (Most Innovative } \\
\text { Companies - MIC). } \\
\quad \text { Creativity } \\
\text { - } \text { potential of human capital: } \\
\text { volume (against the sector), } \\
\text { education, submissions of } \\
\text { innovations; } \\
\text { - intellectual capital: } \\
\text { components, role in a system; } \\
\text { - } \text { the creation of standards: } \\
\text { position in a sector. }\end{array}$ & \\
\hline 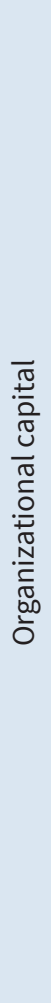 & $\begin{array}{c}\text { Management system: } \\
\text { target market, segmentation } \\
\text { and an offer portfolio; competitive } \\
\text { potential - key competences; } \\
\text { organizational and technological } \\
\text { changes }\end{array}$ & $\begin{array}{l}\text { Organization structure } \\
\text { - } \text { global layout of an agent's } \\
\text { activeness (geographical } \\
\text { divisions); } \\
\text { - } \quad \text { organization of the structure } \\
\text { of a production and service } \\
\text { system (product divisions); } \\
\text { - } \quad \text { evolution of the organization } \\
\text { and management model; } \\
\text { transnationality index (TNI); } \\
\text { geographical spread index (GSI); } \\
\text { - } \text { mergers and acquisitions } \\
\text { (M\&As); transaction number, } \\
\text { value, dynamics and } \\
\text { types: vertical, horizontal, } \\
\text { conglomerate; } \\
\text { - } \text { joint venture; the number and } \\
\text { specificity of contracts signed; } \\
\text { - } \text { relation structures. } \\
\quad \text { Brand strategy } \\
\text { - } \text { brand portfolio; } \\
\text { - } \text { sum of the value of brands in } \\
\text { the agent's portfolio; } \\
\text { - Brand Value (BV); } \\
\text { - } \text { part of Brand Value in Market } \\
\text { Value (BV/MV). }\end{array}$ & 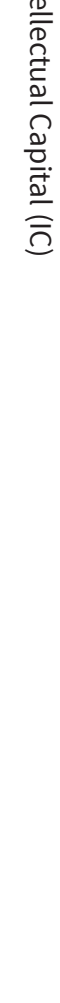 \\
\hline
\end{tabular}


Table 2.1 (cont.)

\begin{tabular}{|c|c|c|c|}
\hline 1 & 2 & 3 & \\
\hline 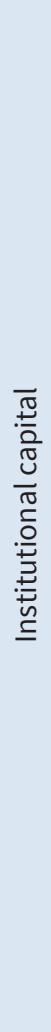 & $\begin{array}{l}\text { Development model: } \\
\text { mission; stakeholders; pillars of } \\
\text { strategy; sustained development; } \\
\text { long-term competitive position }\end{array}$ & 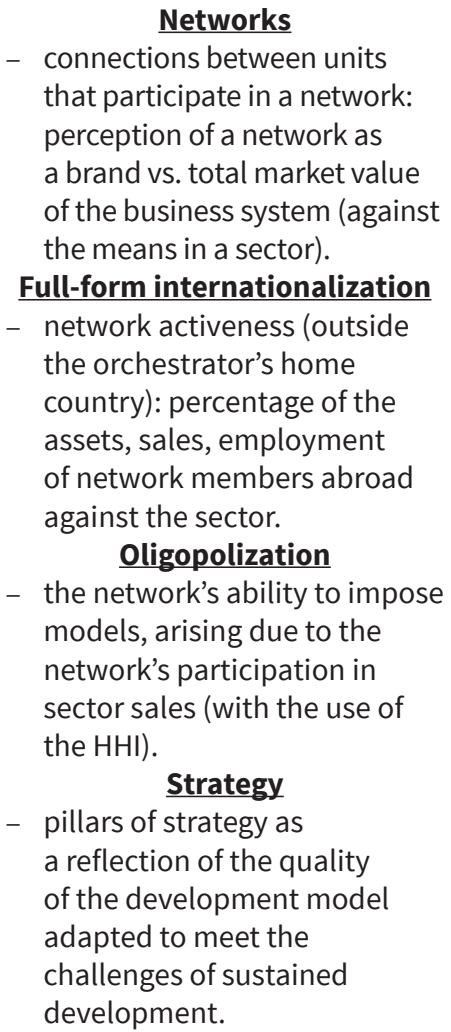 & 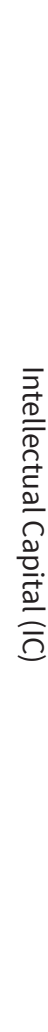 \\
\hline
\end{tabular}

Source: own elaboration based on: M. Rosińska-Bukowska [2012], Rozwój globalnych sieci biznesowych jako strategia konkurencyjna korporacji transnarodowych, Wydawnictwo Uniwersytetu Łódzkiego, Łódź, pp. 106-108

This classification of capital subsystems aims to emphasize the necessity of adopting a systemic approach in assessing a corporation's development potential. It is crucial to value the economic and non-economic layers of TNC capital and understand the permanence of the relations between them.

Economic capital makes it possible to create added value thanks to the dynamics of intellectual capital, which utilizes the structure of relations within a system and congruence with the environment. The systemic nature of TNC capital indicates that factors essential for its increase include not only the financial and production subsystems, but also, to the same degree, the subsystems of intellectual capital based on: innovation, creativity, networking, internationalization, striving for the creation of added value while maintaining the principles of sustainable development, social responsibility as well as building economic and social value. 
The systemic nature of capital makes it possible for Top-TNCs to obtain a unique array of resources on the basis of the synergy effect, occurring thanks to the combination of: the ability to create new technological and organizational solutions, creative management of human resources, reinforcement and expansion of brand portfolios for diverse recipients, creation of an institution of avoiding market mechanism by combining externalization with internalization, globalization with localness, competition with cooperation. It means that it is necessary to include these elements in the assessments of development determinants and prospects for the $21^{\text {st }}$ century Top-TNCs.

\subsection{Asia's largest companies in international rankings}

Rankings classify transnational corporations according to varying criteria. Most take into account several parameters, usually easily measurable economic ones. In order to study the development determinants and prospects of Asian corporations, this work makes use of The Global 2000, a ranking by the prestigious "Forbes" magazine; The World Investment Report (WIR), a ranking issued by the United Nations Conference on Trade and Development and The Best Global Brands (Top 100 Brands) - Interbrand, a classification of the most valuable brands in the world.

The Global 2000 is a list which juxtaposes a corporation's market value, sales, profits and assets. The top positions change often, although the classified group of agents is usually relatively stable throughout longer periods of time. In The World Investment Report the ranks are based on the values of foreign assets, which is crucial when assessing a TNC's ability to explore diverse opportunities provided by the international market. Reports also provide data on: the value of assets, sales and employment (in general and abroad) as well as the transnationality index (TNI) and internationality index (II). Top 100 Brands can be considered an assessment of the quality of goods and services offered by TNCs. The ranking takes into account 100 of the most valuable brands in the world from various business sectors. Therefore, these rankings depict various aspects of TNC activities. Their analysis makes it possible to determine a list of Top-TNCs of a given country/ region which require in-depth research of their development potential (in accordance with previously established requirements of international competitiveness in the $21^{\text {st }}$ century).

In tables 2.2., 2.3., 2.4. positions (with basic data) of Asian TNCs in the top 100 of The Global 2000 (the ranking lists 2000 agents) are presented. Attention has been paid not only to the change in the position of Asian corporations, but also to the changes in the top 10 s of a given ranking. 
Table 2.2. Asian TNCs in the top 100 of The Global 2000 (2018) on the background of Top10 ranking

\begin{tabular}{|c|c|c|c|c|c|}
\hline $\begin{array}{c}\text { Position } \\
\text { in } \\
2018\end{array}$ & Company name & $\begin{array}{c}\text { Sales value } \\
\text { (S) } \\
\text { (bln USD) }\end{array}$ & $\begin{array}{l}\text { Profits } \\
\quad \text { (P) } \\
\text { (bln USD) }\end{array}$ & $\begin{array}{l}\text { Assets } \\
\text { value } \\
\text { (A) } \\
\text { (bln USD) }\end{array}$ & $\begin{array}{c}\text { Market } \\
\text { value (MV) } \\
\text { (bln USD) }\end{array}$ \\
\hline 1 & 2 & 3 & 4 & 5 & 6 \\
\hline 1 & $\begin{array}{l}\text { Industrial and } \\
\text { Commercial Bank of China } \\
\text { (ICBC) }\end{array}$ & 151.4 & 42.0 & 3473.2 & 229.8 \\
\hline 2 & China Construction Bank & 134.2 & 35.0 & 3016.6 & 200.5 \\
\hline 3 & Berkshire Hathaway & 222.9 & 24.1 & 620.9 & 409.9 \\
\hline 4 & JP Morgan Chase & 102.5 & 24.2 & 2513.0 & 306.6 \\
\hline 5 & Wells Fargo & 97.6 & 21.9 & 1943.4 & 274.4 \\
\hline 6 & Agricultural Bank of China & 115.7 & 27.8 & 2816.0 & 149.2 \\
\hline 7 & Bank of America & 92.2 & 16.6 & 2196.8 & 231.9 \\
\hline 8 & Bank of China & 113.1 & 24.9 & 2611.5 & 141.3 \\
\hline 9 & Apple & 217.5 & 45.2 & 331.1 & 752.0 \\
\hline 10 & Toyota Motor & 249.9 & 17.1 & 412.5 & 171.9 \\
\hline 15 & Samsung Electronics & 174.0 & 19.3 & 217.1 & 254.3 \\
\hline 16 & Ping An Insurance Group & 106.6 & 9.5 & 801.0 & 100.8 \\
\hline 21 & China Mobile & 106.8 & 16.4 & 218.9 & 225.3 \\
\hline 25 & $\begin{array}{l}\text { China Petroleum } \\
\text { \& Chemical }\end{array}$ & 255.7 & 7.0 & 216.7 & 105.1 \\
\hline 30 & Mitsubishi UFJ Financial & 49.2 & 8.2 & 2589.8 & 83.9 \\
\hline 34 & Bank of Communications & 53.0 & 10.1 & 1209.2 & 62.2 \\
\hline 37 & Nippon Telegraph \& Tel & 105.0 & 7.4 & 180.3 & 92.2 \\
\hline 38 & Softbank & 82.1 & 8.3 & 213.2 & 78.6 \\
\hline 42 & China Merchants Bank & 44.5 & 9.4 & 855.1 & 66.4 \\
\hline 45 & Japan Post Holdings & 123.7 & 3.1 & 2522.1 & 55.1 \\
\hline 52 & China Life Insurance & 82.8 & 2.9 & 388.7 & 98.1 \\
\hline 55 & $\begin{array}{l}\text { Postal Savings Bank of } \\
\text { China }\end{array}$ & 48.0 & 6.0 & 1189.4 & 55.2 \\
\hline 63 & Industrial Bank & 4.3 & 8.1 & 872.1 & 45.1 \\
\hline
\end{tabular}




\begin{tabular}{|c|c|c|c|c|c|}
\hline 1 & 2 & 3 & 4 & 5 & 6 \\
\hline 64 & $\begin{array}{l}\text { Shanghai Pudong } \\
\text { Development }\end{array}$ & 40.1 & 8.0 & 842.8 & 50.5 \\
\hline 71 & $\begin{array}{l}\text { China State Construction } \\
\text { Engineering }\end{array}$ & 140.8 & 4.9 & 201.4 & 43.2 \\
\hline 72 & Citic Pacific & 49.1 & 5.6 & 933.6 & 41.4 \\
\hline 74 & Honda Motor & 127.9 & 3.9 & 161.8 & 51.4 \\
\hline 75 & China Minsheng Banking & 40.2 & 7.2 & 848.7 & 43.7 \\
\hline 78 & China Citic Bank & 39.7 & 6.3 & 853.5 & 43.1 \\
\hline 84 & $\begin{array}{l}\text { Sumitomo Mitsui } \\
\text { Financial }\end{array}$ & 30.5 & 5.2 & 1648.8 & 48.1 \\
\hline 90 & Mizuho Financial & 29.0 & 6.0 & 1752.3 & 44.4 \\
\hline 95 & Nissan Motor & 105.9 & 4.5 & 157.3 & 38.4 \\
\hline 98 & Hon Hai Precision & 135.2 & 4.6 & 80.4 & 54.4 \\
\hline 102 & PetroChina & 214.8 & 1.2 & 344.9 & 204.5 \\
\hline 104 & Hyundai Motor & 80.7 & 4.7 & 148.1 & 34.2 \\
\hline 108 & SAIC Motor & 112.7 & 4.8 & 85.0 & 43.5 \\
\hline
\end{tabular}

Source: own elaboration based on: The Global 2000/2018, https://www.forbes.com/global2000/list (accessed: 15.03.2019)

Table 2.3. Asian TNCs in the top 100 of The Global 2000 (2012) on the background of Top10 ranking

\begin{tabular}{|c|l|c|c|c|c|}
\hline $\begin{array}{c}\text { Position } \\
\text { in } \\
\mathbf{2 0 1 2}\end{array}$ & \multicolumn{1}{|c|}{ Company name } & $\begin{array}{c}\text { Sales value } \\
\text { (S) } \\
\text { (bln USD) }\end{array}$ & $\begin{array}{c}\text { Profits } \\
\text { (P) } \\
\text { (bln USD) }\end{array}$ & $\begin{array}{c}\text { Assets } \\
\text { value } \\
\text { (A) } \\
\text { (bln USD) }\end{array}$ & $\begin{array}{c}\text { Market } \\
\text { value (MV) } \\
\text { (bln USD) }\end{array}$ \\
\hline 1 & 2 & 3 & 4 & 5 & 6 \\
\hline 1 & Exxon Mobil & 433.5 & 41.1 & 331.1 & 407.4 \\
\hline 2 & JP Morgan Chase & 110.8 & 19.0 & 2265.8 & 170.1 \\
\hline 3 & General Electric & 147.3 & 14.2 & 717.2 & 213.7 \\
\hline 4 & Royal Dutch Shell & 470.2 & 30.9 & 340.5 & 227.6 \\
\hline 5 & $\begin{array}{l}\text { Industrial and Commercial } \\
\text { Bank of China (ICBC) }\end{array}$ & 82.6 & 25.1 & 2039.1 & 237.4 \\
\hline
\end{tabular}


Table 2.3 (cont.)

\begin{tabular}{|c|l|r|r|r|r|}
\hline 1 & \multicolumn{1}{|c|}{2} & \multicolumn{1}{c|}{3} & \multicolumn{1}{c|}{5} & 6 \\
\hline 6 & HSBC Holdings & 102.0 & 16.2 & 2550.0 & 164.3 \\
\hline 7 & PetroChina & 310.1 & 20.6 & 304.7 & 294.7 \\
\hline 8 & Berkshire Hathaway & 143.7 & 10.3 & 392.6 & 202.2 \\
\hline 9 & Wells Fargo & 87.6 & 15.9 & 1313.9 & 178.7 \\
\hline 10 & Petrobras-Petroleo Brasil & 145.9 & 20.1 & 319.4 & 180.0 \\
\hline 25 & Toyota Motor & 228.5 & 4.9 & 358.3 & 147.9 \\
\hline 36 & Mitsubishi UFJ Financial & 53.3 & 7.0 & 2478.8 & 74.5 \\
\hline 45 & Nippon Telegraph \& Tel & 124.0 & 6.1 & 226.6 & 40.6 \\
\hline 59 & Honda Motor & 107.5 & 6.4 & 137.7 & 70.8 \\
\hline 64 & Sumitomo Mitsui Financial & 45.9 & 5.7 & 1654.9 & 47.8 \\
\hline 85 & Nissan Motor & 105.5 & 3.8 & 128.7 & 48.1 \\
\hline 95 & Mitsubishi Corp & 62.6 & 5.6 & 136.6 & 39.7 \\
\hline 98 & Mizuho Financial & 32.2 & 5.0 & 1934.4 & 40.6 \\
\hline
\end{tabular}

Source: own elaboration based on: The Global 2000/2012,

http://www.forbes.pl/rankingi/najwieksze-firmy-swiata-2012,26185 (accessed: 18.04.2012)

Table 2.4. Asian TNCs in the top 100 of The Global 2000 (2006) on the background of Top10 ranking

\begin{tabular}{|c|l|c|c|c|c|}
\hline $\begin{array}{c}\text { Position } \\
\text { in } \\
\mathbf{2 0 0 6}\end{array}$ & Company name & $\begin{array}{c}\text { Sales value } \\
\text { (S) } \\
\text { (bln USD) }\end{array}$ & $\begin{array}{c}\text { Profits } \\
\text { (P) } \\
\text { (bln USD) }\end{array}$ & $\begin{array}{c}\text { Assets } \\
\text { value } \\
\text { (A) } \\
\text { (bln USD) }\end{array}$ & $\begin{array}{c}\text { Market } \\
\text { value (MV) } \\
\text { (bln USD) }\end{array}$ \\
\hline 1 & 2 & 3 & 4 & 5 & 6 \\
\hline 1 & Citigroup & 120.32 & 24.64 & 1494.04 & 230.93 \\
\hline 2 & General Electric & 149.70 & 16.35 & 673.30 & 348.45 \\
\hline 3 & Bank of America & 85.39 & 16.47 & 1291.80 & 184.17 \\
\hline 4 & American Intl Group & 106.98 & 11.90 & 843.40 & 172.24 \\
\hline 5 & HSBC Group & 76.38 & 12.36 & 1274.22 & 193.32 \\
\hline 6 & ExxonMobil & 328.21 & 36.13 & 208.34 & 362.53 \\
\hline 7 & Royal Dutch/Shell Group & 306.73 & 25.31 & 216.95 & 203.52 \\
\hline 8 & BP & 249.47 & 22.63 & 206.91 & 225.93 \\
\hline
\end{tabular}




\begin{tabular}{|c|l|c|c|c|c|}
\hline 1 & \multicolumn{1}{|c|}{2} & \multicolumn{1}{c|}{3} & \multicolumn{1}{c|}{5} & \multicolumn{1}{c|}{6} \\
\hline 9 & JPMorgan Chase & 79.90 & 8.48 & 1198.94 & 144.13 \\
\hline 10 & UBS & 78.25 & 10.65 & 1519.40 & 105.69 \\
\hline 12 & Toyota Motor & 173.09 & 10.93 & 227.05 & 175.54 \\
\hline 32 & Nippon Telegraph \& Tel & 100.82 & 6.63 & 167.67 & 60.38 \\
\hline 44 & Mizuho Financial & 27.96 & 5.85 & 1325.23 & 93.81 \\
\hline 48 & Samsung Electronics & 79.18 & 10.42 & 66.01 & 104.22 \\
\hline 52 & PetroChina & 46.95 & 12.43 & 73.68 & 172.23 \\
\hline 62 & Mitsubishi UFJ Financial & 23.50 & 3.16 & 1024.44 & 143.01 \\
\hline 63 & Honda Motor & 80.71 & 4.54 & 85.72 & 54.65 \\
\hline 77 & $\begin{array}{l}\text { China Pet \& Chem } \\
\text { (Sinopec) }\end{array}$ & 70.32 & 4.35 & 56.78 & 57.05 \\
\hline 98 & Tokyo Electric Power & 47.09 & 2.11 & 124.98 & 36.59 \\
\hline
\end{tabular}

Source: own elaboration based on: The Global 2000/2006, The World's Biggest Public Companies; http://www.forbes.com/lists/2006/18/Rank_3.html (accessed: 06.03.2010)

When analysing the data in The Global 2000 ranking, a major improvement of the position of Asian corporations is visible. In 2018, the top 100 included 28 Asian TNCs, in 2012 - 10, and in 2006 - only 9. In 2018, as many as 5 Asian TNCs held positions in the top 10 of the ranking, while in 2012 - only 2 were listed and in 2006 there were none. It should be mentioned that financial corporations dominate in the top 10 of this ranking (8 out of 10 in 2018). In 2018, a Chinese national financial power, The Industrial and Commercial Bank of China (ICBC), took the first place once again, while the rest of the Chinese „Big Four” took positions in the top 10. China (and Hong Kong) had as many as 309 companies in the Global 2000/2018, Japan - 223 (the United States took the highest number of positions with 575 companies). When "Forbes" published the ranking for the first time, the Global 2000/2003, China and Hong Kong held merely 43 positions on the list, while the USA occupied as many as $776 .^{16}$

The systematic promotion of Asian corporations in The Global 2000 is, therefore, major. However, such analysis of the ranks does not appear to have much use when studying the development determinants and prospects in the sense of an agent's long-term competitiveness. Its major flaw is the combined classification of financial and non-financial corporations, since the value levels of their assets are almost incomparable. When focusing on non-financial corporations, it can be

16 A. Murphy, J. Ponciano, S. Hansen, H. Touryalai [2000], Global 2000. The World's Largest Public Companies, https://www.forbes.com/global2000/\#6686b98f335d (accessed: 09.08.2019). 


\begin{tabular}{|c|c|c|c|c|c|c|c|c|c|c|c|c|c|c|c|c|c|c|c|}
\hline 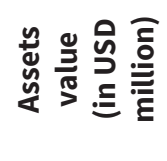 & \multirow{3}{*}{ 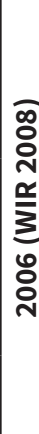 } & 0 & $\begin{array}{l}0 \\
\stackrel{N}{ } \\
\omega \\
\sim \\
\sim\end{array}$ & $\begin{array}{l}\stackrel{m}{\infty} \\
\infty \\
\stackrel{\sim}{\sim} \\
\end{array}$ & $\begin{array}{l}-1 \\
0 \\
- \\
-1 \\
-1\end{array}$ & & $\begin{array}{l}\Omega \\
i n \\
\infty \\
\infty \\
\end{array}$ & $\begin{array}{l}0 \\
0 \\
8 \\
o \\
\end{array}$ & & 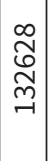 & 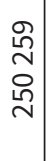 & 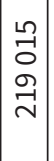 & 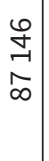 & \begin{tabular}{l}
$\stackrel{\circ}{\circ}$ \\
\multirow{ન}{-1}{} \\
$\stackrel{-}{-}$
\end{tabular} & 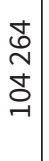 & & & $\begin{array}{l}\text { } \\
\underset{+}{+} \\
\text { }\end{array}$ & $\begin{array}{l}\exists \\
\exists \\
\sim \\
\infty\end{array}$ \\
\hline 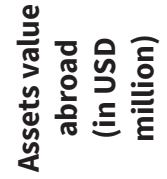 & & $\sigma$ & 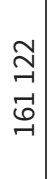 & 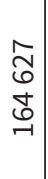 & $\begin{array}{l}0 \\
\tilde{m} \\
o \\
\stackrel{-}{-1}\end{array}$ & & 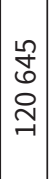 & 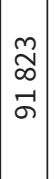 & & $\begin{array}{l}\stackrel{\nu}{m} \\
\stackrel{2}{L} \\
\stackrel{\infty}{\infty}\end{array}$ & 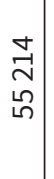 & $\begin{array}{l}m \\
\sigma \\
5 \\
5 \\
\end{array}$ & $\begin{array}{l}\text { ㅇ } \\
\text { O } \\
\text { ㅇ }\end{array}$ & 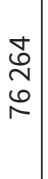 & $\begin{array}{c}\infty \\
\text { } \\
\vec{\sigma} \\
\end{array}$ & & & $\begin{array}{l}\infty \\
0 \\
6 \\
0 \\
1\end{array}$ & 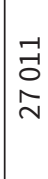 \\
\hline $\begin{array}{c}\text { su!yued u! } \\
\text { uo!ł!sod }\end{array}$ & & $\infty$ & $\nabla$ & $m$ & $v$ & & $\infty$ & $\underset{\neg}{\searrow}$ & & $\neg$ & $\vec{m}$ & 10 & $\vec{\sim}$ & $\stackrel{\infty}{-1}$ & $\stackrel{\sim}{\sim}$ & & & স্ & $\widetilde{\sigma}$ \\
\hline 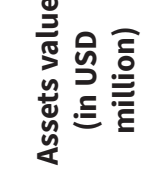 & \multirow{3}{*}{ 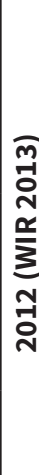 } & r & $\begin{array}{l}\stackrel{\sim}{2} \\
\tilde{m} \\
\stackrel{0}{0} \\
\tilde{m}\end{array}$ & $\begin{array}{l}\vec{y} \\
\infty \\
0 \\
\stackrel{0}{m}\end{array}$ & 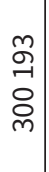 & & 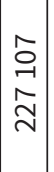 & $\mid \begin{array}{l}\hat{n} \\
N \\
o \\
o \\
y\end{array}$ & & 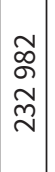 & & $\begin{array}{l}\stackrel{L}{\rho} \\
m \\
m \\
m\end{array}$ & $\begin{array}{l}\stackrel{n}{\sim} \\
\stackrel{1}{m} \\
\stackrel{0}{-1}\end{array}$ & $\begin{array}{l}\vec{J} \\
\infty \\
J \\
J \\
\vec{J}\end{array}$ & 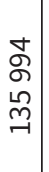 & $\begin{array}{l}\stackrel{\infty}{+} \\
\stackrel{2}{\sim}\end{array}$ & & & \\
\hline 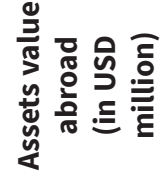 & & 0 & $\begin{array}{l}\infty \\
m \\
o \\
\sim \\
p \\
p\end{array}$ & $\begin{array}{l}\stackrel{m}{O} \\
\stackrel{m}{N} \\
\stackrel{\sim}{N}\end{array}$ & 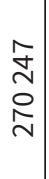 & & 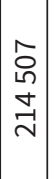 & 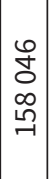 & & 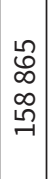 & & $\begin{array}{l}\stackrel{g}{+} \\
\text { m } \\
\stackrel{N}{N}\end{array}$ & $\begin{array}{l}\vec{I} \\
\stackrel{1}{ } \\
\infty\end{array}$ & 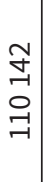 & 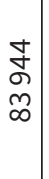 & 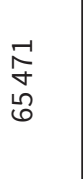 & & & \\
\hline $\begin{array}{l}\text { siu!yued u! } \\
\text { uo!ł!sod }\end{array}$ & & ח & $N$ & $\nabla$ & $m$ & & $n$ & 어 & & $\sigma$ & & 0 & $\stackrel{\sim}{\sim}$ & $\stackrel{\infty}{\rightarrow}$ & 尺 & 웅 & & & \\
\hline 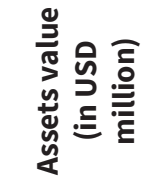 & \multirow{3}{*}{ 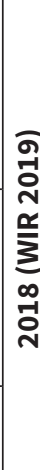 } & $\nabla$ & $\begin{array}{l}0 \\
0 \\
\llcorner \\
8 \\
y\end{array}$ & $\begin{array}{l}\mathbb{N} \\
\infty \\
o \\
o \\
q\end{array}$ & $\begin{array}{l}J \\
\underset{N}{1} \\
\infty \\
\sim \\
\sim\end{array}$ & 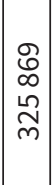 & $\begin{array}{l}\hat{N} \\
\tilde{n} \\
\omega \\
\stackrel{N}{N}\end{array}$ & 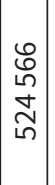 & $\begin{array}{c}0 \\
\tilde{m} \\
\tilde{N} \\
\infty \\
-1\end{array}$ & $\begin{array}{l}\tilde{\vartheta} \\
\infty \\
\tilde{N} \\
\stackrel{\sim}{N}\end{array}$ & $\begin{array}{l}\text { g } \\
\underset{\text { N }}{\text { m }}\end{array}$ & $\left|\begin{array}{l}0 \\
o \\
\overline{1} \\
0 \\
\tilde{m}\end{array}\right|$ & $\begin{array}{l}\hat{n} \\
m \\
\\
\stackrel{n}{-}\end{array}$ & 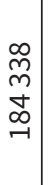 & 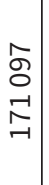 & $\begin{array}{l}\text { : } \\
0 \\
\text { O } \\
\text {-1 }\end{array}$ & $\begin{array}{l}\stackrel{\sim}{\sim} \\
\stackrel{\sim}{N} \\
\text { ㄱ. }\end{array}$ & 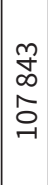 & $\begin{array}{l}\hat{n} \\
0 \\
\text { + } \\
\text { m }\end{array}$ \\
\hline 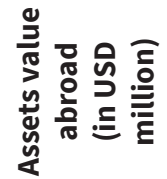 & & $m$ & $\begin{array}{l}m \\
\stackrel{\sim}{1} \\
m \\
\tilde{m}\end{array}$ & 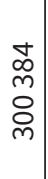 & $\begin{array}{l}\stackrel{m}{N} \\
\stackrel{n}{ } \\
\stackrel{\omega}{\sim}\end{array}$ & \begin{tabular}{|l|}
$\stackrel{2}{0}$ \\
m \\
o \\
N
\end{tabular} & $\begin{array}{c}\tilde{D} \\
0 \\
m \\
\end{array}$ & 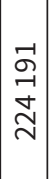 & 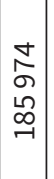 & $\begin{array}{c}0 \\
8 \\
-1 \\
-1 \\
-1\end{array}$ & 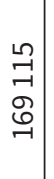 & 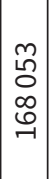 & 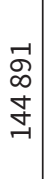 & $\begin{array}{l}\stackrel{0}{0} \\
\underset{N}{m} \\
\stackrel{J}{-}\end{array}$ & 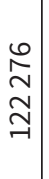 & $\begin{array}{l}\text { \& } \\
G \\
\emptyset \\
0\end{array}$ & $\begin{array}{l}\stackrel{\infty}{f} \\
\text { Ln } \\
\stackrel{-}{0}\end{array}$ & $\underset{\infty}{\stackrel{\sim}{n}}$ & 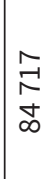 \\
\hline $\begin{array}{c}\text { su!yued u! } \\
\text { uo!t!sod }\end{array}$ & & $N$ & -1 & $N$ & $m$ & $\nabla$ & | & 0 & $\sim$ & $\infty$ & $\sigma$ & 으 & $\stackrel{m}{\rightarrow}$ & $\underset{\exists}{ }$ & i & $\vec{m}$ & $\stackrel{m}{m}$ & $\stackrel{\infty}{m}$ & శ్ \\
\hline 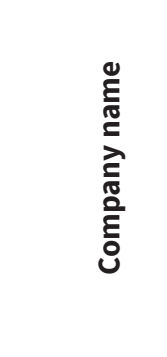 & & $\neg$ & 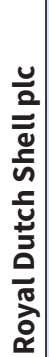 & 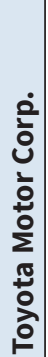 & 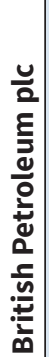 & 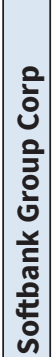 & \begin{tabular}{|l} 
\\
$\frac{\pi}{\pi}$ \\
$\frac{\pi}{0}$ \\
\end{tabular} & 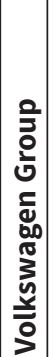 & 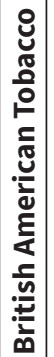 & 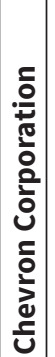 & 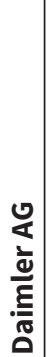 & 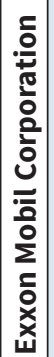 & 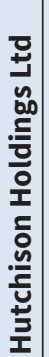 & 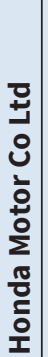 & 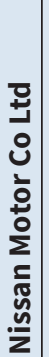 & 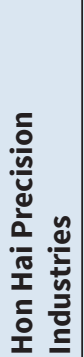 & 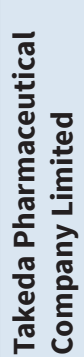 & 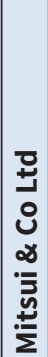 & 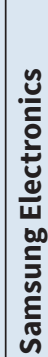 \\
\hline
\end{tabular}




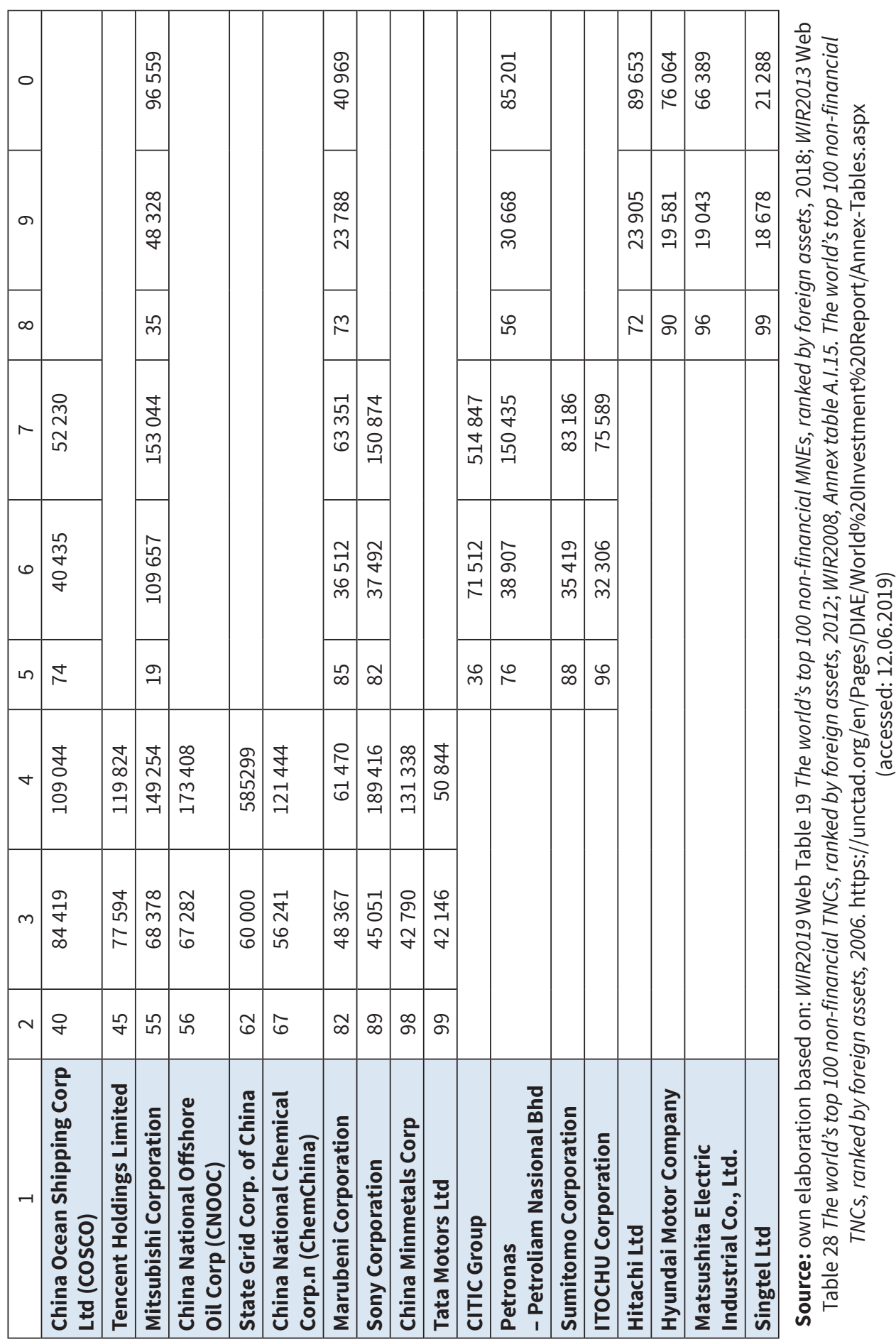


seen that Asian Top-TNCs listed in the top 100 of the ranking belong mostly to the automotive sector (Toyota, Honda, Nissan, Mitsubishi). In 2018, Samsung Electronics, a representative of the electronics sector, took a high $15^{\text {th }}$ place (while in 2006 it was in the $48^{\text {th }}$ position).

Another ranking analysed in terms of the positions of Asian TNCs is The World Investment Report (WIR). Financial and non-financial corporations are classified in different WIR rankings and, therefore, they do not have the same flaw as The Global 2000. By referring to the Top100 non-financial TNCs WIR, the international activeness of corporations can be assessed, since the ranking lists TNCs in order of the size of their foreign assets (table 2.5.).

In the whole WIR2019 ranking (data from 2018), 19 out of the listed 100 TNCs are Asian corporations (including 2 in the top 10), in 2012 (WIR2013) there were 13 of them (including 1 in the top 10), while in 2006 (WIR2008) - 11 (including 1 in the top 10). It suggests that although the advancement of Asian corporations is visible, their potential for the exploration of global business space is still fairly limited. Additionally, what may attract the reader's attention is the fact that Asian corporations that have improved their positions and taken high places in the ranking are mostly automotive, such as Toyota, Honda or Nissan. Aside from them, the only Asian corporations maintaining their positions in the top 100 of the WIR in 2006-2018 were multi-sector holding companies: Mitsubishi, Marubeni, Hutchison. Corporations in the electronics sector, such as Samsung, Sony, Hitachi or Matsushita, have never had stable positions, similarly to the automotive Hyundai and Tata.

Another ranking which helps assessing the position of Asian corporations among the most powerful global competitors is the classification of the most valuable global brands (table 2.6.).

Table 2.6. Asian brands among the most valuable global brands - (values given in billions of USD) in the years 2006-2018 according to The Best Global Brands (Top 100 Brands)

\begin{tabular}{|c|c|c|c|c|c|c|c|c|c|c|}
\hline Brand name & 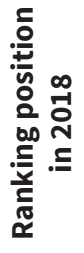 & 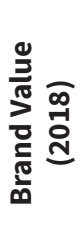 & 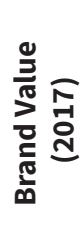 & 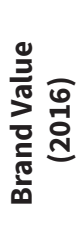 & 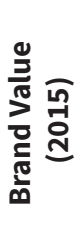 & 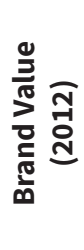 & 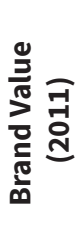 & 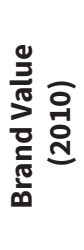 & 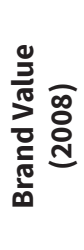 & 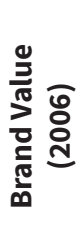 \\
\hline 1 & 2 & 3 & 4 & 5 & 6 & 7 & 8 & 9 & 10 & 11 \\
\hline Samsung & 6 & 59.9 & 56.2 & 51.8 & 45.3 & 32.9 & 23.4 & 19.5 & 17.7 & 16.2 \\
\hline Toyota & 7 & 53.4 & 50.3 & 53.6 & 49.0 & 30.3 & 27.8 & 26.2 & 34.0 & 27.9 \\
\hline Honda & 20 & 23.7 & 22.7 & 22.1 & 23.0 & 17.3 & 19.4 & 18.5 & 19.1 & 17.0 \\
\hline Hyundai & 36 & 13.5 & 13.2 & 12.5 & 11.3 & 7.5 & - & - & - & 4.1 \\
\hline
\end{tabular}




\begin{tabular}{|l|c|c|c|c|c|c|c|c|c|c|}
\hline \multicolumn{1}{|c|}{1} & \multicolumn{1}{c|}{2} & \multicolumn{1}{c|}{3} & \multicolumn{1}{c|}{4} & \multicolumn{1}{c|}{5} & \multicolumn{1}{c|}{6} & \multicolumn{1}{c|}{7} & 8 & 9 & 10 & 11 \\
\hline Nissan & 40 & 12.2 & 11.5 & 11.1 & 9.1 & 5.0 & 3.8 & - & - & 3.1 \\
\hline Canon & 55 & 10.4 & 9.8 & 11.1 & 11.3 & 12.0 & 11.7 & 11.5 & 10.9 & 10.0 \\
\hline Sony & 59 & 9.3 & 8.5 & 8.3 & 7.7 & 9.1 & 9.9 & 11.4 & 13.6 & 12.7 \\
\hline Huawei & 68 & 7.6 & 6.7 & 5.8 & 4.9 & - & - & - & - & - \\
\hline Kia & 71 & 6.9 & 6.9 & 6.3 & 5.7 & 4.1 & - & - & - & - \\
\hline Panasonic & 76 & 6.3 & 6.0 & 6.4 & 6.4 & 5.8 & 5.0 & 4.3 & 4.3 & 4.0 \\
\hline Nintendo & 99 & 4.7 & - & - & - & 7.1 & 7.7 & 9.0 & 8.8 & 6.6 \\
\hline Subaru & 100 & 4.2 & - & - & - & - & - & - & - & - \\
\hline Lenovo & - & - & 4.0 & 4.0 & 4.1 & - & - & - & - & - \\
\hline Lexus & - & - & - & - & - & - & - & - & 3.6 & 3.1 \\
\hline LG & - & - & - & - & - & - & - & - & - & 3.0 \\
\hline
\end{tabular}

"-" The brand was not included in the Top 100 Brands ranking in a given year.

Source: own elaboration based on: The 100 Top Brands [2006-2007], BusinessWeek, August 6, 2007, pp. 59-64 (pdf); The Best Global Brands [2008], https://www.interbrand.com/best-brands/ best-global-brands/2008/ranking/; The Best Global Brands [2009], http://www.interbrand.com/

Best_Global_Brands.aspx (accessed: 16.04.2010); The Best Global Brands [2010-2018],

http://www.interbrand.com/en/knowledge/best-global-brands-2010.aspx;

https://www.interbrand.com/best-brands/best-global-brands/2016/ranking/; https://www. interbrand.com/best-brands/best-global-brands/2017/ranking/; https://www.interbrand.com/ best-brands/best-global-brands/2018/; https://www.interbrand.com/best-brands/best-globalbrands/2019/ranking/ (accessed: 14.09.2019)

The presented analysis of the value of Asian brands over the years 2006-2018 indicates that out of the 100 perceived as the most valuable brands in the world, 15 are Asian; 7 of them are automotive brands while 8 belong to the electronics sector in the broad sense. Corporations that own them have also taken top positions in some of the international rankings discussed earlier. Therefore it can be said that apart from a strong representation of the financial sector (Forbes Global 2000 classification), Asia also currently boasts a major competitive position in the automotive and electronics sectors. From the perspective of Top-TNC positions, it remains merely a contender for the global top positions in other fields, although it systematically and dynamically begins to force its way in.

When summarizing the analyses conducted on the basis of international rankings of Top-TNCs, a statement may be made that the position of Asian corporations improves by the year. The Asian TNCs that have taken strictly top positions in individual rankings maintain and even strengthen their positions. Yet, since the listed classifications - The Top 100 Global Brands, The Forbes Global 2000, The World 
Investment Report - focus on selected parameters, it is hard to explicitly assess the ability of Asian corporations to adapt to the constantly changing environment and, therefore, determine their perspectives for long-term development. It would require in-depth synthetic studies of individual business sectors, which would make it possible to recognize the real development potential of Asian TNCs in specific fields.

\subsection{Asian corporations in light of the research that utilizes a synthetic measure}

In light of the theory presented in earlier subchapters regarding the essential attributes of the functioning of Top-TNC as a system of connected vessels and indicating the significance of the systemic nature of corporation capital in building long-term competitiveness, it appears reasonable to utilize multi-faceted research to identify the agents best prepared to face modern challenges. The positioning of Asian Top-TNCs against the leading global corporations has been done on the basis of synthetic indices.

A measure calculated by "Fortune" on the basis of nine parameters and used to identify The World's Most Admired Companies (MAC) was used as reference. The values of the MAC indicator for leaders of sector-specific rankings were juxtaposed with the positions of Asian corporations in the same rankings. Additionally, an authorial indicator of the creation of added value was calculated - it encompasses five parameters, illustrating five layers of corporation capital that constitute the pillars of the system of building competition. In both cases, the research is sector-specific, which makes it possible to make comparisons. The work focuses on the study of the automotive and electronics sectors. The basis for the selection of these sectors was the fact that, as the analysis of international rankings (tables 2.2.-2.6.) has proven, the representatives of these sectors are the strongest non-financial Asian corporations.

Referring to The World's Most Admired Companies (MAC) is reasonable, since the areas under study reflect the enumerated requirements for building competitiveness in the $21^{\text {st }}$ century. A corporation's position in the MAC is the result of a complex assessment ${ }^{17}$ of: the ability to attract and retain talented employees; quality of management; social responsibility to the community and the environment;

17 Currently 9 parameters: the ability to attract and retain talented people; the quality of management; social responsibility to the community and the environment; innovativeness; quality of products or services; wise use of corporate assets; financial soundness; long-term investment value; effectiveness of doing global business. Up until 2008 there were only 8 parameters. 
innovativeness; quality of products and services; wise use of corporate assets; financial soundness; long-term investment value; the effectiveness of running a global business. The list of 50 of the most admired corporations is prepared on the basis of the aggregated measure of their development potential. Companies are selected for the MAC list via the Fortune 1000 and Global 500 lists. The number of TNCs in a business sector oscillates between the minimum 6 and the maximum 15. To obtain their position, TNCs need to have an income of approximately 10 billion USD and be among the best in their sector in terms of income size. The more agents in a given sector competing in an international arena, the more companies there are in a given industry group. ${ }^{18}$ For the purposes of sector-specific rankings, the general score of a TNC is calculated on the basis of an average of the results of each of the 9 parameters - each calculated by ascribing a score from zero ("weak") to ten ("perfect"). Corporations with the best results in a given industry sector are deemed "the most admired". However, it should also be mentioned that the interpretation of the significance of each quality is left to the respondents.

In tables 2.7., 2.8. and 2.9. the values of the MAC measure of the Asian corporations ranked in the motor vehicles sector as well as the computers and electronics sector are presented. Out of all sectors, Asian corporations are the strongest representatives of these - which appears to be in accordance with the research results presented earlier in light of the Forbes, UNCTAD and Interbrand rankings.

Table 2.7. The most admired Asian automotive corporations (against the ranking leader) according to The World's Most Admired Companies in the years 2006-2018

\begin{tabular}{|l|c|c|c|c|c|c|c|c|}
\hline \multirow{2}{*}{$\begin{array}{c}\text { Company } \\
\text { name }\end{array}$} & $\mathbf{2 0 1 8}$ & $\mathbf{2 0 1 6}$ & $\mathbf{2 0 1 4}$ & $\mathbf{2 0 1 2}$ & $\mathbf{2 0 1 0}$ & $\mathbf{2 0 0 8}$ & $\mathbf{2 0 0 6}$ \\
\cline { 2 - 8 } & \multicolumn{6}{|c|}{ MAC value (position in the industry ranking in a given year) } \\
\hline 1 & 2 & 3 & 4 & 5 & 6 & 7 & 8 \\
\hline $\begin{array}{l}\text { BMW } \\
\text { (leader) }\end{array}$ & $7.02(2)$ & $6.60(2)$ & $7.68(1)$ & $7.12(2)$ & $6.94(1)$ & $7.88(1)$ & $7.07(2)$ \\
\hline $\begin{array}{l}\text { Toyota } \\
\text { (leader) }\end{array}$ & $7.91(1)$ & $7.70(1)$ & $6.96(2)$ & $6.04(4)$ & $5.20(3)$ & $7.86(2)$ & $7.51(1)$ \\
\hline Honda Motor & $5.55(6)$ & $5.50(5)$ & $5.44(6)$ & $5.10(8)$ & $5.32(2)$ & $6.80(4)$ & $6.33(3)$ \\
\hline
\end{tabular}

18 "Respondents are asked to identify the 10 companies they admire most, regardless of industry, from a list of companies that ranked in the top $25 \%$ of all companies the previous year; ranked in the top 3 within their industry the previous year (top 4 for non-U.S. companies); or a company that ranked among the top 50 All-Stars last year and did not make any of the above cuts. Excluded are companies on last year's list that were not admired, i.e., did not rank in the top $50 \%$ of their industry, and companies on this year's list that were not on last year's list". Korn Ferry Institute [2018], Reports \& Insights FORTUNE World's Most Admired Companies, January 19, 2018, https://www.kornferry.com/institute/fortune-worlds-mostadmired-companies-2018 (accessed: 09.09.2019). 
Table 2.7 (cont.)

\begin{tabular}{|l|c|c|c|c|c|c|c|}
\hline \multicolumn{1}{|c|}{1} & 2 & 3 & 4 & 5 & 6 & 7 & 8 \\
\hline Nissan Motor & $5.17(8)$ & $5.10(8)$ & - & $5.05(9)$ & $3.08(10)$ & $6.12(7)$ & $6.04(4)$ \\
\hline $\begin{array}{l}\text { Hyundai } \\
\text { Motor }\end{array}$ & $5.40(10)^{\star}$ & $5.60(4)$ & $5.40(8)$ & $5.87(6)$ & $4.49(5)$ & $5.56(14)$ & $5.39(9)$ \\
\hline Suzuki Motor & & & & & $3.83(9)$ & $5.85(9)$ & $4.70(13)$ \\
\hline Mazda Motor & & & & & $3.76(13)$ & $5.66(12)$ & $5.51(7)$ \\
\hline $\begin{array}{l}\text { Dongfeng } \\
\text { Motor }\end{array}$ & & & & & $3.11(14)$ & & \\
\hline $\begin{array}{l}\text { Shanghai } \\
\text { Automotive }\end{array}$ & & & & $3.76(13)$ & & & \\
\hline
\end{tabular}

*according to MAC 2019

Source: own elaboration based on: The World's Most Admired Companies in years 2006-2019

Table 2.8. The most admired Asian electronics corporations (against the ranking leader) according to The World's Most Admired Companies in the years 2006-2018

\begin{tabular}{|c|c|c|c|c|c|c|c|}
\hline \multirow{2}{*}{$\begin{array}{c}\text { Company } \\
\text { name }\end{array}$} & 2018 & 2016 & 2014 & 2012 & 2010 & 2008 & 2006 \\
\hline & \multicolumn{7}{|c|}{ MAC value (position in the industry ranking in a given year) } \\
\hline 1 & 2 & 3 & 4 & 5 & 6 & 7 & 8 \\
\hline $\begin{array}{l}\text { General } \\
\text { Electric } \\
\text { (leader) }\end{array}$ & $6.40(2)^{\star}$ & $6.40(2)$ & $7.17(1)$ & $6.82(1)$ & $7.07(1)$ & $8.40(1)$ & $8.29(1)$ \\
\hline $\begin{array}{l}\text { Samsung } \\
\text { Electronics }\end{array}$ & $6.70(2)$ & $6.40(3)$ & $6.99(2)$ & $6.50(2)$ & $6.74(2)$ & $6.48(6)$ & $6.88(3)$ \\
\hline $\begin{array}{l}\text { LG } \\
\text { Electronics }\end{array}$ & $5.93(7)$ & & $5.54(5)$ & $4.74(12)$ & $5.79(7)$ & $6.41(7)$ & $6.39(6)$ \\
\hline Sony & $6.13(6)$ & $5.90(6)$ & & $5.98(4)$ & $6.29(4)$ & $7.01(2)$ & $6.53(5)$ \\
\hline $\begin{array}{l}\text { Panasonic } \\
\text { (Matsushita } \\
\text { Electric) }\end{array}$ & & $6.00(5)$ & & $5.48(7)$ & $5.92(6)$ & $6.20(10)$ & $6.12(11)$ \\
\hline $\begin{array}{l}\text { Mitsubishi } \\
\text { Electric }\end{array}$ & $\begin{array}{l}5.92 \\
(11)^{\star \star \star} 8\end{array}$ & & $\begin{array}{c}5.58(8)^{\star \star \star} \\
(13 \text { in } \\
2014)\end{array}$ & $4.72(13)$ & $5.48(12)$ & $6.05(12)$ & $6.29(8)$ \\
\hline Hitachi & & $5.80(8)$ & & $4.76(11)$ & $5.38(13)$ & $6.17(9)$ & $6.16(10)$ \\
\hline Toshiba & & & & $5.37(8)$ & $5.67(9)$ & $6.30(8)$ & $6.22(9)$ \\
\hline Sharp & & & & $5.10(10)$ & $5.49(11)$ & $6.16(11)$ & $6.29(7)$ \\
\hline $\begin{array}{l}\text { Sumitomo } \\
\text { Electric }\end{array}$ & & & & 4.60 (14) & $5.18(14)$ & $5.84(13)$ & $6.12(11)$ \\
\hline
\end{tabular}




\begin{tabular}{|l|l|l|l|l|l|l|c|}
\hline \multicolumn{1}{|c|}{1} & 2 & 3 & 4 & 5 & 6 & 7 & 8 \\
\hline $\begin{array}{l}\text { Sanyo } \\
\text { Electric }\end{array}$ & & & & & & $5.53(14)$ & $5.60(13)$ \\
\hline $\begin{array}{l}\text { Hon Hai } \\
\text { Precision } \\
\text { Industry }\end{array}$ & & & & & & $5.22^{\star \star}$ & $5.21(15)$ \\
\hline
\end{tabular}

* Siemens - leader; ${ }^{\star \star}$ sector change; ${ }^{* \star \star}$ according to MAC 2015; ${ }^{\star \star \star \star}$ according to MAC 2019

Source: own elaboration based on: The World's Most Admired Companies in years 2006-2019

Table 2.9. The most admired Asian computer corporations (against the ranking leader) according to The World's Most Admired Companies in the years 2006-2018

\begin{tabular}{|l|c|c|c|c|c|c|c|c|}
\hline \multirow{2}{*}{$\begin{array}{c}\text { Company } \\
\text { name }\end{array}$} & $\mathbf{2 0 1 8}$ & $\mathbf{2 0 1 6}$ & $\mathbf{2 0 1 4}$ & $\mathbf{2 0 1 2}$ & $\mathbf{2 0 1 0}$ & $\mathbf{2 0 0 8}$ & $\mathbf{2 0 0 6}$ \\
\cline { 2 - 8 } & \multicolumn{7}{|c|}{ MAC value (position in the industry ranking in a given year) } \\
\hline $\begin{array}{l}\text { Apple } \\
\text { (leader) }\end{array}$ & $8.53(1)$ & $8.60(1)$ & $7.94(1)$ & $8.42(1)$ & $7.95(1)$ & $7.42(1)$ & $7.31(3)^{\star}$ \\
\hline Canon & $6.05(6)$ & $5.50(8)$ & $5.94(6)$ & $6.01(5)$ & $6.12(6)$ & $6.56(7)$ & $6.88(6)$ \\
\hline Fujitsu & $5.80(6)$ & $6.10(4)$ & $5.91(7)$ & $5.41(9)$ & $5.06(13)$ & $5.29(12)$ & $5.83(14)$ \\
\hline $\begin{array}{l}\text { Asustek } \\
\text { Computer }\end{array}$ & $5.78(7)$ & $6.10(4)^{\star \star}$ & $6.20 * \star *$ & - & $5.00(14)$ & $4.85(15)$ & - \\
\hline $\begin{array}{l}\text { Lenovo } \\
\text { Group }\end{array}$ & $5.58(9)^{\star \star \star \star}$ & $6.50(3)$ & $6.30(3)$ & $5.16(10)$ & $5.21(11)$ & $5.05(13)$ & - \\
\hline NEC & - & - & - & $4.90(12)$ & $4.93(15)$ & $6.34(11)$ & $5.84(13)$ \\
\hline Acer & - & - & - & $4.62(16)$ & $5.60(19)$ & - & - \\
\hline
\end{tabular}

* IBM - leader $(7,67) ;{ }^{* *}$ sector change; ${ }^{* \star *}$ according to MAC 2015; **** according to MAC 2019

Source: own elaboration based on: The World's Most Admired Companies in years 2006-2019

The analysis has shown that in 2006 there were 81 Asian TNCs in the MAC ranking; 64 out of them were Japanese (20\% of them were the most admired corporations in their sectors), 8 Chinese, 6 South Korean, 2 Singaporean, 1 Taiwanese. ${ }^{19}$ In 2008, 79 Asian corporations took their places in the ranking: 53 Japanese corporations (22 in the top positions of their sectors), as many as 14 Chinese corporations, but none classified as the most admired TNCs; 6 South Korean (including 3 leaders), 2 Singaporean (both leaders), 3 Taiwanese (pretenders) and 1 Indian corporation (pretender). Therefore, it should be emphasized that Asia has been dynamically entering the competitive fight for the top positions in individual sectors for a decade.

19 Fortune Global Most Admired Companies [2006], https://money.cnn.com/magazines/fortune/ globalmostadmired/countries/S.html (accessed: 25.09.2019). 
In-depth studies make it possible to notice that the positions of the most admired corporations in the world in 2008 were held only by 27 Asian companies and as many as 90 TNCs from the United States. The analysis of the newest (2019) World's Admired Companies ranking proves that the Asian TNC with the highest position is the $18^{\text {th }}$ - Singapore Airlines. Despite the fact that half of the biggest technological companies are Chinese, the topmost place achieved by a Chinese company (the Alibaba company) was $34^{\text {th }}$, although the company is perceived as a rival of the second place holder - Amazon (the biggest retailer in the world). ${ }^{20}$ The two subsequent Chinese TNCs are Tencent Holdings and Qingdao Haier. In the automotive sector, the Japanese Toyota may be the leader, but despite Honda, Nissan and Hyundai being in the top 8 of the most admired corporations, all of them hold places in the second half of the ranking (positions 5, 6 and 7, respectively, that is pretenders). In 2019, the three most admired Asian corporations in the electronics sector were: Samsung, LG and Sony (places 2, 4 and 7, respectively). In 2019, in the computer sector, Asian corporations were no match for the American leaders (Apple, Dell, HP) and take the $5^{\text {th }}, 6^{\text {th }}$ and $7^{\text {th }}$ position: Canon, Asustek and Lenovo, respectively.

In conclusion, the study on the basis of the MAC 2006-2019 has shown that among the most admired global companies in the automotive and widely-perceived electronics sectors there are few Asian Top-TNCs with stable and secure positions. They include: Toyota, Honda, Nissan, Hyundai as well as Samsung, LG, Sony and Canon. Some of the studied corporations have a large potential, however they need to not only systematically adjust their offers, but also modify their management models in accordance with the presented standards, in order to threaten the positions of long-standing leaders of individual industry sectors. The group includes: Lenovo, Asustek, Hitachi, Mitsubishi, Suzuki and Mazda.

To assess the development determinants and prospects of Asian TNCs, the most admired corporations of the automotive and electronics sectors have been studied again using a different a synthetic measure: the Synthetic Indicator of Creation of Added Value - SICAV. The concept of assessing the ability to create added value is based on the assumption that each layer of a corporation's capital participates in the long-term development potential. The effective fulfilment of strategy signifies: the increase in profits, volume, market value, brand value, research and development expenditures, internationalization indices etc. However, in order to assess a TNC's potential for increasing the ability to create added value, a comprehensive assessment of these parameters is of highest significance. Therefore, those parameters were taken into account in the measure, while maintaining the principle of referring to each individual layer and in the end emphasizing: the profitability of equity, expenditures on research and development referred to employment, the range of

20 J. Koetsier [2019], Apple Most-Admired Global Company, Says Fortune, https://www.forbes. com/sites/johnkoetsier/2019/01/22/ (accessed: 02.09.2019). 
drawing upon the multi-cultural potential of human capital, arbitrage abilities that are the result of locating assets on the international market, the significance of intangible assets for the ability to create sales value.

The use of SICAV requires the calculation of five parameters: [ROE], [(R\&D)/E], [(MV - SE)/S], [AVA/A], [EA/E]. Return on equity (ROE) is a synthetic measure of the market and financial potential, or several interacting business aspects. To value the influence of innovation and structural as well as institutional changes on the improvement of competitive position, two indices were included: the expenditures on research and development per employee $[(\mathrm{R} \& \mathrm{D}) / \mathrm{E}]$ and the percentage of intangible assets in the creation of sales value $[(\mathrm{MV}-\mathrm{SE}) / \mathrm{S}]$. When accentuating the significance of a corporation's multi-level connection system, the internationalization of assets and employment has been referred to - the research includes the percentage of assets abroad in the value of total assets [AVA/A] as well as the percentage of employment abroad in employment in general [EA/E]. Thus, the appreciation of the role of the global arrangement of value chains, investment locations, including the structure of strategic alliances, mergers and international acquisitions, or the resources, experiences and competences of the corporate system was attempted.

SICAV fulfils the requirements of long-term aggregated assessment of a corporation's development determinants and prospects against its main competition in a given industry sector. An advantage of SICAV is the use of comparable quantitative data published in international reports and obtaining parameters that, through their correct aggregation, provide the image of all crucial components reflecting individual layers of a corporation's capital.

In table 2.10. SICAV values (2007-2018) for the automotive sector are presented, while values for the electronics sector are presented in table 2.11. The research took into account the companies whose offers compete with those of the studied Asian TNCs.

Table 2.10. Synthetic indicator (SICAV) for the examined group of automotive sector TNCS

\begin{tabular}{|l|c|c|c|c|c|c|c|c|c|c|c|c|}
\hline $\begin{array}{c}\text { Company } \\
\text { name }\end{array}$ & $\mathbf{2 0 0 7}$ & $\mathbf{2 0 0 8}$ & $\mathbf{2 0 0 9}$ & $\mathbf{2 0 1 0}$ & $\mathbf{2 0 1 1}$ & $\mathbf{2 0 1 2}$ & $\mathbf{2 0 1 3}$ & $\mathbf{2 0 1 4}$ & $\mathbf{2 0 1 5}$ & $\mathbf{2 0 1 6}$ & $\mathbf{2 0 1 7}$ & $\mathbf{2 0 1 8}$ \\
\hline \multicolumn{1}{|c|}{1} & 2 & 3 & 4 & 5 & 6 & 7 & 8 & 9 & 10 & 11 & 12 & 13 \\
\hline $\begin{array}{l}\text { General } \\
\text { Motors }\end{array}$ & 0.000 & 1.000 & 0.249 & 0.640 & 0.522 & 0.447 & 0.266 & 0.673 & 0.764 & 0.823 & 0.518 & 0.753 \\
\hline Ford Motor & 0.723 & 0.677 & 0.866 & 0.000 & 0.555 & 0.755 & 0.680 & 0.961 & 0.745 & 0.876 & 0.740 & 0.816 \\
\hline Volkswagen & 0.765 & 0.828 & 0.819 & 1.000 & 0.583 & 0.659 & 0.349 & 1.000 & 0.805 & 0.698 & 0.599 & 0.537 \\
\hline BMw & 0.790 & 0.073 & 0.224 & 0.612 & 0.832 & 1.000 & 0.950 & 0.881 & 0.673 & 0.722 & 0.635 & 0.697 \\
\hline Daimler & 0.590 & 0.000 & 0.000 & 0.067 & 0.296 & 0.417 & 0.185 & 0.604 & 0.707 & 0.626 & 0.681 & 0.670 \\
\hline Renault & 0.825 & 0.487 & 0.072 & 0.723 & 0.703 & 0.713 & 0.223 & 0.716 & 0.749 & 0.917 & 0.872 & 1.000 \\
\hline
\end{tabular}


Table 2.10 (cont.)

\begin{tabular}{|l|c|c|c|c|c|c|c|c|c|c|c|c|}
\hline \multicolumn{1}{|c|}{1} & 2 & 3 & 4 & 5 & 6 & 7 & 8 & 9 & 10 & 11 & 12 & 13 \\
\hline Fiat & 0.807 & 0.788 & 0.528 & 0.422 & 1.000 & 0.752 & 1.000 & 0.872 & 0.746 & 0.957 & 1.000 & 0.886 \\
\hline Toyota & 0.947 & 0.345 & 0.134 & 0.322 & 0.000 & 0.000 & 0.437 & 0.896 & 1.000 & 1.000 & 0.798 & 0.869 \\
\hline Nissan & 0.710 & 0.572 & 0.549 & 0.487 & 0.613 & 0.339 & 0.627 & 0.927 & 0.884 & 0.965 & 0.815 & 0.851 \\
\hline Honda & 1.000 & 0.613 & 1.000 & 0.815 & 0.489 & 0.598 & 0.726 & 0.937 & 0.782 & 0.869 & 0.738 & 0.759 \\
\hline Hyundai & 0.525 & 0.124 & 0.373 & 0.189 & 0.278 & 0.549 & 0.210 & 0.678 & 0.737 & 0.818 & 0.767 & 0.523 \\
\hline Mitsubishi & 0.716 & 0.057 & 0.504 & 0.569 & 0.039 & 0.023 & 0.000 & 0.000 & 0.000 & 0.000 & 0.000 & 0.000 \\
\hline
\end{tabular}

Source: own elaborations. Interpretation of results: 1,000 - leader, 0,000 - lowest position

Table 2.11. Synthetic indicator (SICAV) for the examined group of electronic sector TNCS

\begin{tabular}{|l|l|l|l|l|l|l|l|l|l|l|l|l|}
\hline $\begin{array}{c}\text { Company } \\
\text { name }\end{array}$ & $\mathbf{2 0 0 7}$ & $\mathbf{2 0 0 8}$ & $\mathbf{2 0 0 9}$ & $\mathbf{2 0 1 0}$ & $\mathbf{2 0 1 1}$ & $\mathbf{2 0 1 2}$ & $\mathbf{2 0 1 3}$ & $\mathbf{2 0 1 4}$ & $\mathbf{2 0 1 5}$ & $\mathbf{2 0 1 6}$ & $\mathbf{2 0 1 7}$ & $\mathbf{2 0 1 8}$ \\
\hline Philips & 0.500 & 0.399 & 0.497 & 0.624 & 0.498 & 0.536 & 0.398 & 0.000 & 0.015 & 0.348 & 0.144 & 0.509 \\
\hline GE & 0.550 & 0.284 & 0.701 & 0.575 & 0.523 & 0.510 & 0.429 & 0.451 & 0.265 & 0.604 & 0.226 & 0.000 \\
\hline Apple & 0.530 & 0.530 & 0.766 & 0.597 & 0.593 & 0.752 & 0.372 & 0.652 & 0.564 & 0.609 & 0.652 & 1.000 \\
\hline Intel & 0.196 & 0.270 & 0.638 & 0.415 & 0.359 & 0.372 & 0.293 & 0.415 & 0.305 & 0.687 & 0.948 & 0.723 \\
\hline Microsoft & 0.542 & 0.470 & 0.815 & 0.552 & 0.401 & 0.465 & 0.567 & 0.412 & 0.602 & 0.601 & 0.753 & 0.842 \\
\hline IBM & 0.668 & 0.386 & 0.812 & 0.837 & 0.832 & 1.000 & 0.854 & 0.922 & 0.767 & 0.759 & 0.893 & 0.960 \\
\hline Electrolux & 0.853 & 0.535 & 1.000 & 0.909 & 0.614 & 0.815 & 0.650 & 0.887 & 0.596 & 0.808 & 0.997 & 0.996 \\
\hline Siemens & 0.637 & 0.301 & 0.658 & 0.337 & 0.517 & 0.462 & 0.272 & 0.727 & 0.493 & 0.507 & 0.644 & 0.813 \\
\hline Samsung & 0.000 & 0.155 & 0.774 & 0.577 & 0.449 & 0.565 & 0.595 & 0.325 & 0.281 & 0.252 & 0.580 & 0.729 \\
\hline Hitachi & 0.088 & 0.256 & 0.000 & 0.325 & 0.633 & 0.756 & 0.450 & 1.000 & 0.441 & 0.386 & 0.599 & 0.900 \\
\hline Sony & 1.000 & 1.000 & 0.861 & 1.000 & 1.000 & 0.930 & 1.000 & 0.706 & 1.000 & 1.000 & 1.000 & 0.907 \\
\hline LG & 0.215 & 0.000 & 0.500 & 0.000 & 0.000 & 0.000 & 0.000 & 0.286 & 0.000 & 0.000 & 0.000 & 0.426 \\
\hline
\end{tabular}

Source: own elaborations. Interpretation of results: 1,000 - leader, 0,000 - lowest position

The results of the multi-faceted research (SICAV) indicate that in the automotive sector Asian corporations that are deemed the most admired in the MAC study really begin to determine the standards for the industry. Their positions are strong and stable. Japanese Mitsubishi Motor was included in the study in order to check whether a company that is known on the automotive market, but has no position among the top MAC, really has no chance with its rivals that change their pillars of development in accordance with the modern requirements. However, 
the results are not as unambiguous in the electronics sector. There were more corporations studied (which was supposed to, for example, reflect the competition for Samsung's extensive offer: Apple, Siemens, Philips, Electrolux), which resulted in a shuffle. An electronics sector in the broad sense actually remains leaderless, although the Japanese Sony is the closest to fulfilling the role. In this case, a question that needs answering is to what extent can the agents with wide and diverse offers be juxtaposed with those focused on a small section of market activities. The dilemma became clear during the MAC analyses, where the top positions changed yearly and some corporations migrated between the sectors.

In conclusion, the study focused on the positioning of Asian Top-TNCs against the leading world corporations that remain their direct competitors (including studying the competition of individual TNC product division with a wide offer). On the basis of the study of TNCs in the automotive and electronics sector, it can be claimed that the most admired Asian Top-TNCs (included in the MAC) belong to the global top in these areas, since they base their development prospects on the synergy of economic and intellectual capitals, which was confirmed by the study using SICAV.

\subsection{The most powerful Asian non-financial transnational corporations}

The research conducted proves that the most powerful Asian non-financial transnational corporations (top 10) are the automotive Toyota Motor (Japan), Honda Motor (Japan), Nissan Motor (Japan), Hyundai Motor (South Korea) and in the electronics sector: Samsung Electronics (South Korea), LG Electronics (South Korea), Sony (Japan), Canon (Japan), Lenovo Group (China), Panasonic/Matsushita Electric (Japan). Therefore, the top 10 includes 4 corporations from the Asian Emerging Markets Economies (the A-EMEs). The use of international rankings made it possible to initially determine the position of Asian corporations in the global economy. The financial and market states (The Global 2000), the position on the international market (The World Investment Report), building the values of product brands (The Top 100 Global Brands) were the essential foundations for the assessment of development determinants.

The assessment of development prospects taking into account the requirements of competitiveness in the $21^{\text {st }}$ century required references to studies based on synthetic measures that cumulate parameters regarding the system of Top-TNC attributes. Two concepts of aggregated assessment were utilized. The first one involved the study of: human capital, management quality; social responsibility, 
innovativeness, the quality of products/services; the use of corporate assets, financial stability, long-term investment value, business efficiency on the international market (The World's Most Admired Companies - MAC). The second one was the study of: the return on equity, expenditures for research and development per one employee, the range of drawing upon the multi-cultural potential of human capital, arbitrage abilities that are the result of locating assets on the international market and the significance of intangible assets for the ability to create sales value (Synthetic Indicator of Creation of Added Value - SICAV).

By using the above-mentioned concepts of MAC and SICAV, which attempt to meet the challenge of assessing development prospects of TNCs on the basis of the co-existing determinants responsible for the effectiveness of utilizing the range of resources owned (including capital from both the economic layers that constitute the competence base and the intellectual layers with the multiplier effect), it has been determined that in the automotive sector, the Asian TNCs - Toyota Motor, Honda Motor, Nissan Motor and Hyundai Motor - are considered the most admired and start setting standards in the industry. Their positions are stable and secure as a result of them adopting an expansion strategy suitable to meet new challenges.

A characteristic feature of their strategy is the pressure put on the foundations of financial condition but also, equally, attention to human capital (all categories of stakeholders). The new approach is also expressed through the manner of offer presentation, for instance: presenting elements that increase road safety as key qualities or the use of alternative drive sources. These elements influence customer reviews and increase corporation value. What may be surprising (in light of the research) is that Asian corporations pay much less attention to product and service innovation than their European or American rivals (Hyundai appears the weakest, but so does, e.g., Nissan).

The study of the corporations in the electronics sector has shown that the most admired Asian corporations - Samsung, LG, Sony - become involved in direct competition among the most powerful corporations of the sector. Innovativeness, management of human resources, product quality are the main strong points of Samsung and Sony. ${ }^{21}$ It should be mentioned that in terms of innovation and management of human resources Asian TNCs (such as, e.g. Canon) remain far behind in comparison with other corporations. In the computers sector, Asian Canon, Asustek and Lenovo are no match for the American leaders (Apple, Dell, HP).

In the zone of new technologies, in the broad sense, a dynamic growth of the young companies from the A-EMEs (Asustek, Lenovo, HTC, Huawei) is clearly visible, which may indicate that they build their pillars of growth on the basis of modern concepts (the systemic 4C approach) from the start. On the other hand, research

21 The World's Most Admired Companies [2019], https://fortune.com/worlds-most-admiredcompanies/2019/ (accessed: 28.09.2019). 
has shown that several of the Asian (Japanese) corporations present on the international market for years now, e.g. Hitachi, Mitsubishi, Suzuki, Mazda, have troubles maintaining their positions in the global top rankings. They face the key challenge of not merely refining their products/services, but also remodelling the development concept to meet the requirements of competitiveness in the $21^{\text {st }}$ century.

In conclusion, the study conducted has confirmed that for the Asian TNCs to obtain leading positions in individual sectors, an accumulation of a sufficient multi-layer economic and intellectual capital is required, as is a proper exploration of all its components, both material and non-material. The improvement of market positions of Asian TNCs (including those from the A-EMEs) as a result of the implementation of the rules of building competitiveness in the $4 \mathrm{C}$ model is clearly visible. Putting emphasis on the more ecological approach to corporation management translates into a systematic improvement in the position (e.g. Kia, Huawei, Asustek, Lenovo).

The presented analysis for 2006-2018 indicates that Asia currently boasts a major competitive position among non-financial corporations in the automotive and electronics sectors, which is confirmed by all analyses conducted. For instance, among 100 brands perceived as the most valuable in the world, 7 brands out of the 15 Asian ones are automotive, while 8 belong to the electronics sector. Their owners take the leading positions in each of the mentioned international rankings. Strong position of Asian TNCs in the automotive and electronics sectors has also been confirmed by the studies conducted with the use of synthetic measures.

When analysing the research results for corporations from the A-EMEs, strong position of Korean agents is easily discernible (Samsung, LG, Hyundai, Kia) and so is the growing potential of Chinese companies (Lenovo, Huawei) or Taiwanese ones (Asutek, HTC). However, 50\% of the Asian non-financial companies in the global top are still Japanese corporations. Thus, it is clear that a change in economic leadership in a region is not visible right away, since an international business is perceived from the angle of the most powerful agents in a given sector (Top-TNCs).

It should be mentioned that Forbes Global 2000/2019 lists as many as nine automotive corporations from the A-EMEs, including: seven Chinese (SAIC Motor, Dongfeng Motor Group, Guangzhou Automobile Group, BYD, Great Wall Motor, BAIC Motor, Chongqing Changan Auto) and two Indian ones (Tata Motors, Mahindra \& Mahindra). However, their positions in the ranking are low. ${ }^{22}$ Forbes Global 2000/2019 for the computers sector also lists two Chinese corporations, Legend Holding and Unisplendour as well as six Taiwanese ones: Quanta Computer, Compal Electronics, Wistron, Inventec, Innolux and Asustek Computer. All

22 SAIC Motor - 100, Dongfeng Motor Group - 618, Guangzhou Automobile Group - 658, BYD - 737, Tata Motors - 769, Great Wall Motor - 842, BAIC Motor - 927, Mahindra \& Mahindra - 973, Chongqing Changan Auto - 1642. 
of them hold low positions (Legend took the highest position of 677). ${ }^{23}$ Although the first four places are held by American leaders, Asian Top-TNCs, including 8 corporations from the A-EMEs, took the subsequent ten positions in this sector.

Asian Top-TNCs have swiftly climbed their way to the top of the financial sector. The in-depth research presented in this work did not encompass financial corporations, yet a reference to the Forbes Global 2000 classification makes it possible to determine that the whole Chinese "Big Four" (Industrial and Commercial Bank of China, China Construction Bank, Agricultural Bank of China, Bank of China) are in the very top of financial giants. ${ }^{24}$ The financial sector is much more susceptible to outside factors than the non-financial sector. In the classic production and service (non-financial) areas, entering the global top of the most powerful players demands meeting several requirements simultaneously. Therefore, to obtain a real assessment of development determinants and prospects, a multi-faceted approach is needed. To maintain international competitiveness, a corporation must be able to systematically explore all capital layers, both economic and intellectual. Therefore, on the basis of international rankings based on the classic quantitative parameters, a selection of the most powerful corporations in a given sector can be determined. Those corporations require in-depth study in order to evaluate their long-term development prospects. This concerns corporations in all areas/regions/countries.

\section{Conclusions}

In conclusion, in accordance with the requirements of building competitiveness in the $21^{\text {st }}$ century, modern corporations must base their development potential on the strength of qualitative changes - to the management process, the production of innovative goods and services, the co-creation of values together with their institutional environment. ${ }^{25}$ For the Top-TNCs, a flexibility-ensuring strategy

23 Legend Holding - 677, Unisplendour - 1882 and as many as six Taiwanese: Quanta Computer - 939, Compal Electronics - 1463, Wistron - 1579, Inventec - 1773, Innolux - 1934, Asustek Computer - 1971.

24 Eleven subsequent Chinese banks are classified in the Global 2000 Forbes 2019 in the Major Banks category.

25 E. Hoddy [2018], Critical realism in empirical research: employing techniques from Grounded theory Methodology, "International Journal of Social Research Methodology", vol. 22; M. Srivastava, A. Tranklin, L. Martinette [2013], Building a Sustainable Competitive Advantage, "Journal of Technology Management and Innovation", vol. 8 (2); M. Rosińska-Bukowska [2019], Human Capital and Intellectual Capital in Modern International Business - Based on Studies of the Strategies of Transnational Corporations, "Comparative Economic Research", vol. 22 (2), pp. 141-158. 
based on balancing expenditures and benefits, determining a hierarchy of purposes, the sequence of key actions and the pace of their realization are the essence of success. Asian corporations, especially those from the A-EMEs (China, India, Taiwan), have quickly understood these requirements and are successfully implementing them as pillars of their strategies, which may accelerate their expansion in the nearest future.

The study conducted in these chapter has confirmed that the Asian TNCs obtain leading positions in global economy using a combination of a multi-layer economic and intellectual capital. The presented analysis for 2006-2018 indicates that Asia currently boasts a major competitive position of non-financial corporations (especially in the automotive and electronics sectors) and financial TNCs (although they were beyond the scope of these chapter). The improvement of positions of Asian TNCs is a result of the implementation of the rules relating to building competitiveness on the basis of network connections. The network approach requires cooperation and in the case of corporations it is based on the development of foreign direct investment (FDI) and international mergers and acquisitions (M\&As) - these issues are the subject of the next part of this monograph (chapter 3). 



\title{
Chapter 3
}

\section{The social network analysis of Chinese cross-border mergers and acquisitions}

\author{
Dominika Brózda-Wilamek ${ }^{*}$
}

(iD) https://orcid.org/0000-0002-0513-2286

It is well known that the dynamic development of emerging market economies has had a significant impact on the shape of contemporary international economic relations. People's Republic of China (PRC) plays a particularly significant role among the developing countries of the world. The growth of the Chinese economic power continues to take place on many levels. One of them is the growing activity of China's enterprises in the field of foreign direct investment (FDI) in the global mergers and acquisitions (M\&As) market. It is associated with, among others, the implementation of the 'Go Global' strategy, the Chinese accession to the World Trade Organization (WTO) ${ }^{1}$ and the possession of vast foreign exchange reserves that need to be invested in alternative ways.

The purpose of this part of the monography is to assess the geographical and industrial structure of Chinese cross-border mergers and acquisitions (CBM\&As) between the years 2000 and 2017. The study is carried out using social network analysis (SNA). In this chapter the network nature of cross-border business combination, in which the acquiring company is a Chinese firm and the target company is from a country other than China, is presented. The research sample consists of business sectors in which companies are involved in cross-border transactions on the global M\&As market.

* University of Lodz, Department of International Business and Trade.

1 From 2001 its participation in WTO has created not only opportunities for Chinese companies to expand their trade but also intensive competition between local and foreign enterprises within the domestic market. 


\subsection{The network analysis as the M\&A's research tool}

Network analysis (based on SNA) gives the scientists the opportunity to explore statistical data from a new point of view. SNA is an interdisciplinary research method having a wide range of applications in biology, informatics, math, sociological, and physics. Increasingly, it is also used in economics to study business networks, economic networks, and trade networks. For instance, De Benedictis et al. have analysed the centrality and importance of individual countries in the world trade network. ${ }^{2}$

Academic literature that uses network analyses to study international financial flows is gradually increasing, although its application to the analysis of foreign investment is still relatively incipient. Some studies have focused on analysing international financial crises (Elliott et al.), ${ }^{3}$ and the shareholding structures of transnational enterprises (Vitali and Battiston). ${ }^{4}$ Some contemporary research on CBM\&As using SNA tools has also been carried out, among others, by Sánchez Díez et al. ${ }^{5}$ or Mirc. ${ }^{6}$

In the SNA, the network as a research object is defined by a set of nodes and the relations between them. Thus, two main elements forming a network can be distinguished:

1) nodes - entities included in the system;

2) edges - relationships that reflect interactions between entities in the system. Networks are often presented in the form of graphs. Graphically, the node (vertex) is presented as a point (circle) and the edge (connection) as a straight line linking two nodes. ${ }^{7}$

The literature emphasizes that SNA measures can be considered both from the perspective of the entire network and individual entities. The first group of measures includes, among others: ${ }^{8}$

2 L. De Benedictis, S. Nenci, G. Santoni, L. Tajoli, C. Vicarelli [2014], Network analysis of world trade using the BACI-CEPII dataset, "Global Economy Journal”, vol. 14 (3/4), pp. 287-343.

3 M. Elliott, B. Golub, M.O. Jackson [2014], Financial networks and contagion, "American Economic Review", vol. 104 (10), pp. 3115-3153.

4 S. Vitali, S. Battiston [2014], The community structure of the global corporate network, "PLoS ONE", vol. 9 (8), e104655, pp. 1-13.

5 A. Sánchez Díez, P. Galaso Reca, J.M. García de la Cruz [2017], Mergers and acquisitions carried out by Spanish firms in Latin America: a network analysis study, "CEPAL Review", vol. 2016 (120), pp. 51-69.

6 N. Mirc [2015], Merging networks - contributions and challenges of social network analysis to study mergers and acquisitions, in: A. Risberg, D. King, O. Meglio (eds.), Routledge Companion on Mergers and Acquisitions, Routledge, London, pp. 259-271.

7 S. Mazurek [2016], Identyfikacja sieci w gospodarce, "Prace Naukowe Uniwersytetu Ekonomicznego we Wrocławiu", vol. 448, p. 168.

8 K. Fuks, A. Kawa, B. Pierański [2014], Zastosowanie mierników SNA w analizie sieci przedsiębiorstw, "Marketing i Rynek", vol. 5 (CD), p. 49. 
- density;

- diameter;

- clustering coefficient;

- small world effect.

In this chapter, only the density as part of the measures relating to the entire Chinese CBM\&As network will be determined. This indicator refers the proportion of possible ties among the members of a network.

The second group of measures include centrality ${ }^{9}$ indicators which are necessary to analyse the position of a given entity in the network. There are four basic types: ${ }^{10}$

- degree centrality;

- closeness centrality;

- prestige centrality;

- betweenness centrality.

The interpretation of these indicators should be adapted to the type of considered network. Due to the specifics of this study, only the value of the first three of them will be calculated.

The degree centrality allows to specify the number of connections of a given node with other vertices. ${ }^{11}$ In this study, this indicator reflects the number of M\&As between industries. If an industry is directly connected to many other industries, then its degree centrality is high and it is at the centre of the whole network. Therefore, this coefficient determines the relative importance of particular industry in CBM\&As transactions that are undertaken by Chinese businesses. For the directed network ${ }^{12}$ additional parameters can also be designated: $:^{13}$

- out-degree centrality - its level is determined on the basis of connections pointing away from the given node. In this chapter, this indicator allows identifying the main sectors from which the Chinese enterprises are expanding their activities through CBM\&As;

- in-degree centrality - its level is determined on the basis of connections towards the inside of a given node. In this study, this indicator allows identifying the main industry sectors in which Chinese enterprises invest abroad through CBM\&As.

9 Centrality - is a mathematical concept present in graph and network theory. This indicator allows determining the relevance of a particular vertex in the considered graph.

10 S. Yang, F.B. Keller, L. Zheng [2017], Social network analysis: methods and examples, Sage Publications, Los Angeles, CA, p. 61.

11 A. Sánchez Díez et al. [2017], op. cit., pp. 57-58.

12 The directed network - is a network that is made up of a set of nodes connected by edges, where the edges have a direction associated with them.

13 H. Lee, I. Sohn [2016], Big Data w przemyśle. Jak wykorzystać analizę danych do optymalizacji kosztów procesów?, Wydawnictwo Naukowe PWN, Warszawa, p. 103. 
Another essential indicator determining the position of a node in the system is the closeness centrality, which measures the average length of the shortest paths between nodes on the graph. It refers the average distance from a given node to all other nodes in the network. The high value of this measure indicates that it has an impact on the closest entities. Therefore, it can be stated that in this study, a high closeness centrality allows identifying business sectors that are key in the cross-industrial expansion of Chinese enterprises and participate in conglomerate M\&As.

Finally, the prestige centrality, that is also known as eigenvector centrality, indicates the relative importance of a node in a network based on the node's connections. It refers which vertices are associated with the most related nodes forming the network. ${ }^{14}$ The node's eigenvector measures the closeness of an entity to other 'central' entities, therefore the central location of a given business sector depends on the centrality of the main industries in the network. ${ }^{15}$ This indicator is used to identify the most prestigious vertices, including flagship entities. It determines the quality of connections between nodes. The high value of the eigenvector centrality indicates that the nodes are leaders in the network, because they have many relations with other entities that hold a significant position in the system.

\subsection{Chinese cross-border mergers and acquisitions}

The integration of developing and transition economies with the global market has resulted in a huge inflow of FDI to their countries. However, in recent years, a growing share of these countries in international capital flows as capital exporters in the form of CBM\&As has been recorded. ${ }^{16}$ In the last two decades, CBM\&As carried out by emerging market companies have grown tremendously and played a significant role at the global level. According to UNCTAD, emerging market corporations conducted $22 \%$ of the world's CBM\&As in the period 2015-2017, against only $8 \%$ between 2000 and 2002 (table 3.1.).

According to the data presented in table 3.1., it can be seen that during the period 2015-2017 China became a net investor for the first time. The outflow of direct investments from this country was higher than the inflow. Furthermore, between 2000 and 2017 the share of Chinese FDI (including CBM\&As) in global transactions was systematically increasing. Particularly noteworthy is the fact that during

14 H. Lee, I. Sohn [2016], op. cit., p. 111.

15 C. Aller, L. Ductor, M.J. Herrerias [2015], The world trade network and the environment, "Energy Economics", vol. 52, p. 59.

16 E. Radomska [2018], Chińskie bezpośrednie inwestycje zagraniczne w Unii Europejskiej - kontrowersje i wyzwania, “KNUV”, vol. 2 (56), p. 85. 
2015-2017, the share of Chinese FDI outflows accounted for 39\% of developing economies' outflow transactions, against 6\% during 2000-2002. What is more, taking into account the net value of CBM\&As, between 2015 and 2017 China held:

- second place in the world with $12 \%$ share, after United States (14\%), followed by Canada (9\%), Japan (8\%) and United Kingdom (8\%);

- first place among developing economies with 54\% share, ahead of Hong Kong (11\%), Singapore (8\%) and United Arab Emirates (4\%).

Table 3.1. Basic statistics on Chinese FDI in the period 2000-2017

\begin{tabular}{|c|c|c|c|c|c|c|}
\hline & 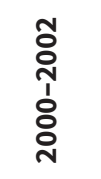 & 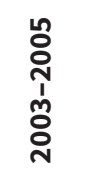 & 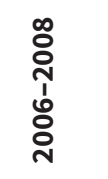 & 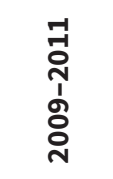 & 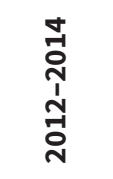 & 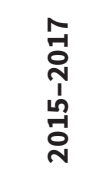 \\
\hline & 1 & 2 & 3 & 4 & 5 & 6 \\
\hline \multicolumn{7}{|c|}{ FDI (mln USD) } \\
\hline Outflow FDI from China & 3440 & 6871 & 33349 & 66665 & 106256 & 166702 \\
\hline Inflow FDI to China & 46778 & 62180 & 88183 & 111240 & 124497 & 134461 \\
\hline \multicolumn{7}{|c|}{ FDI outflows (\%) } \\
\hline $\begin{array}{l}\text { Share of developing } \\
\text { economies' FDI outflows in } \\
\text { global transactions }\end{array}$ & 8.0 & 11.0 & 15.0 & 24.0 & 31.0 & 28.0 \\
\hline $\begin{array}{l}\text { Share of Chinese FDI } \\
\text { outflows in global } \\
\text { transactions }\end{array}$ & 1.0 & 1.0 & 2.0 & 5.0 & 8.0 & 11.0 \\
\hline $\begin{array}{l}\text { Share of Chinese FDI } \\
\text { outflows in developing } \\
\text { economies }\end{array}$ & 6.0 & 8.0 & 13.0 & 21.0 & 26.0 & 39.0 \\
\hline \multicolumn{7}{|c|}{ number of net cross-border M\&As by purchaser (\%) } \\
\hline $\begin{array}{l}\text { Share of Chinese CBM\&As } \\
\text { number in global } \\
\text { transactions }\end{array}$ & 0.0 & 1.0 & 1.0 & 2.0 & 4.0 & 5.0 \\
\hline $\begin{array}{l}\text { Share of Chinese CBM\&As } \\
\text { number in developing } \\
\text { economies }\end{array}$ & 5.0 & 7.0 & 7.0 & 14.0 & 20.0 & 28.0 \\
\hline \multicolumn{7}{|c|}{ value of net CBM\&As by purchaser (\%) } \\
\hline $\begin{array}{l}\text { Share of developing } \\
\text { economies' CBM\&As value } \\
\text { in global transactions }\end{array}$ & 8.0 & 12.0 & 16.0 & 25.0 & 41.0 & 22.0 \\
\hline
\end{tabular}


Table 3.1 (cont.)

\begin{tabular}{|l|c|c|c|c|c|c|}
\cline { 2 - 6 } \multicolumn{1}{c|}{} & 1 & 2 & 3 & 4 & 5 & 6 \\
\hline $\begin{array}{l}\text { Share of Chinese CBM\&As } \\
\text { value in global transactions }\end{array}$ & 0.0 & 1.0 & 3.0 & 8.0 & 13.0 & 12.0 \\
\hline $\begin{array}{l}\text { Share of Chinese CBM\&As } \\
\text { value in developing } \\
\text { economies' transactions }\end{array}$ & 1.0 & 7.0 & 15.0 & 32.0 & 32.0 & 54.0 \\
\hline
\end{tabular}

Source: own elaboration based on: UNCTAD, World Investment Report: Annex Tables 2019, www.unctad.org/fdistatistics (accessed: 16.09.2019)

Between 2000 and 2017 the overseas expansion of Chinese enterprises was closely related to the pro-investment policy implemented by the PRC authorities. In this policy, the 'Go Global' initiative launched in 1999 and adopted as part of the 10th Five Year Plan (2001-2005), played a crucial role. Gu and Reed emphasize that the 'Go Global' policy had three main purposes: ${ }^{17}$

- it was to alleviate the pressure to the Renminbi (RBM) appreciation;

- it was to sustain the sufficient resources for China's growth;

- it was to improve Chinese companies competitiveness through the assimilation of modern business practices and the appropriation of foreign technology.

One major element of the 'Go Global' strategy was to promote the overseas mergers and acquisitions by providing incentives and loosening the control over outward investments ${ }^{18}$ made by Chinese companies. ${ }^{19}$ The 'Go Global' policy has particularly encouraged resource-related companies to acquire businesses abroad that could secure energy and other natural resources for China's growth over the medium to long term. For this reason, acquisitions carried out by resource-related bidders have been more likely to be supported politically and financially by the central government than those in any other industry. ${ }^{20}$

In 2006, the Chinese government reinforced the 'Go Global' policy in its 11 th Five-Year Plan the years 2006-2010, aiming to bring the corporate sector in line with China's globalization. Then the 12th Five-Year Plan (2011-2015) has introduced clear targets in the strategy, including a $17 \%$ increase in overseas investment by $2015 .^{21}$

17 L. Gu, W.R. Reed [2013], Chinese overseas M\&A performance and the go global policy, "Economics of Transition", vol. 21 (1), pp. 162-163.

18 Outward investment requires approval by China's Ministry of Commerce, with concomitant foreign currency approval from the State Administration of Foreign Exchange (SAFE).

19 L. Gu, W.R. Reed [2013], op. cit., p. 162.

20 N. Hu, Y.I. Zhang, S. Tan [2016], Determinants of Chinese cross-border M\&As, "Annals of Economics and Finance", vol. 17 (1), p. 210.

21 Ibidem, p. 213. 
The most recent five-year plan for the years 2016-2020, adopted in March 2016 by the People's National Assembly of China, has also pointed out the crucial role of outward FDI for the development of Chinese economy. It has indicated that enterprises should invest abroad and increase deliveries of Chinese equipment and services to foreign projects. It has also expected that Chinese companies would increase cooperation with foreign partners in order to acquire technology. ${ }^{22}$

What is more, Radomska indicates that the increase in Chinese overseas investment activity in the form of CBM\&As can be explained by the rise in foreign exchange reserves resulting from the current account surplus with a simultaneous positive balance in capital account. The importance of the 'Made in China 2025' strategy that was adopted in 2015 by the Chinese government is also emphasised. This strategy is focused on raising innovation and competitiveness of the Chinese economy. It assumes to raise the country to a leading position in terms of technology, among others, through investments in the international mergers and acquisitions market. ${ }^{23}$

Furthermore it is worth emphasizing that in China a significant proportion of CBM\&As is undertaken by state-owned enterprises (SOEs) which are potentially managed differently from typical companies in a market-oriented economy. Therefore, it could be concluded that government plays an important role in the business activities of Chinese firms and actively supports enterprises in their internationalization process. Some Chinese corporations receive a lot of support from the PRC authorities in acquiring foreign entities, since these transactions are related to achieving the long-term goals of the entire economy. ${ }^{24}$ It is worth noting that for $\mathrm{Gu}$ and Reed that additional support has come in the form of preferential treatment for outward-investing Chinese companies in matters such as tax benefits, direct grants, low- or no-interest loans and access to foreign exchange. ${ }^{25}$

Research findings available in the literature point out that between 2000 and 2017 Chinese CBM\&As were motivated primarily by the desire to increase their market share in the global market. On one hand, Boateng et al. indicate that these transactions carried out in the period 2000-2004 enabled Chinese entities to speed up the entry into new markets, promote diversification and obtain foreign advanced technology and other resources. ${ }^{26}$

On the other hand, Klimek emphasizes that in the period 2013-2015 the most significant motive of Chinese enterprises' overseas expansion was to bring strategic

22 A. Klimek [2016], Cross-border mergers and acquisitions by Chinese state-controlled enterprises, “Prace Naukowe Uniwersytetu Ekonomicznego we Wrocławiu”, vol. 447, pp. 150-151.

23 E. Radomska [2018], op. cit., p. 95.

24 A. Klimek [2013], Efekty międzynarodowych fuzji i przejęć dokonanych przez korporacje transnarodowe z Chin, "International Journal of Management and Economics", vol. 38, p. 38.

25 L. Gu, W.R. Reed [2013], op. cit., p. 162.

26 A. Boateng, W. Qian, Y. Tianle [2008], Cross-border M\&As by Chinese firms: An analysis of strategic motives and performance, "Thunderbird International Business Review", vol. 50 (4), p. 259. 
assets to the headquarters and at the same time to home economy. Chinese FDI, carried out in the form of CBM\&As, were meeting the objectives of the Chinese government and the strategy of development in the coming years. CBM\&As were also designed to increase the level of Chinese companies' internationalization, but at the same time to strengthen the global position of China's economy. ${ }^{27}$

\subsection{The results of the Chinese CBM\&As network study using SNA indicators}

In an attempt to use social network analysis indicators to study Chinese FDI, CBM\&As network consisting of nodes (i.e. business sectors) and edges (reflecting mergers and acquisitions) was used. For the purposes of the survey, Thomson Reuters database was used, where 2626 of such connections were identified between 2000 and 2017.

The visualization of the cross-industry network of connections was presented in the form of a directed graph, where the edges go from the acquirer industry to the target industry. On figure 3.1. and figure 3.2. the Chinese CBM\&As network in 2000 and 2017 respectively was presented. The size of the node depends on the value of its centrality degree. Nodes that are not connected by edges with other vertices indicate that only intra- industry connections occurred in a given year.

Transportation $\&$ Infrastructure

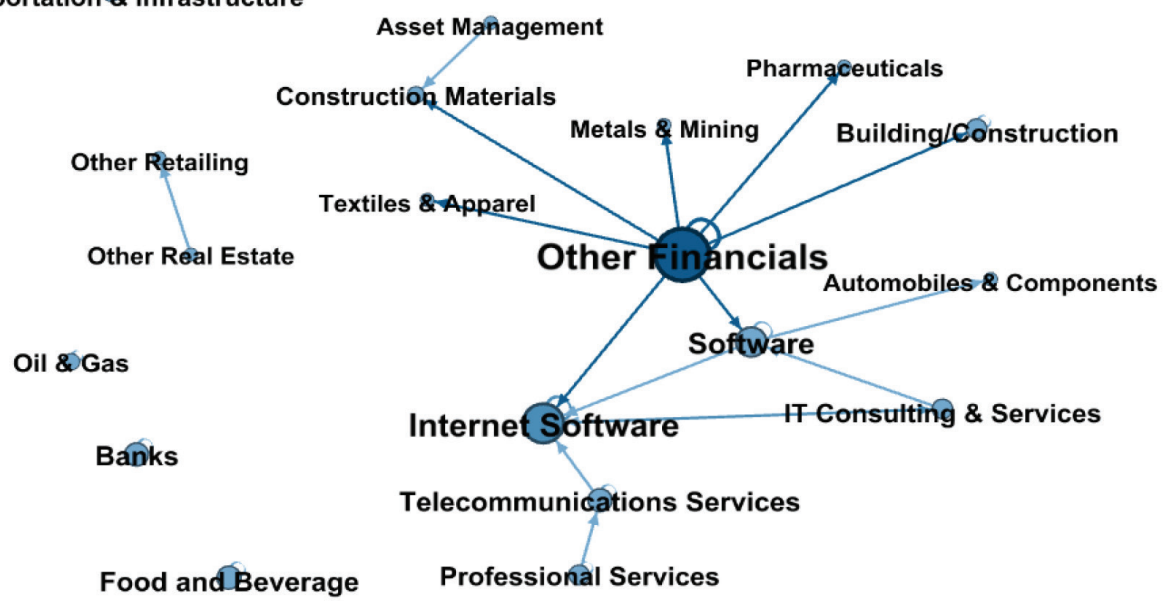

Figure 3.1. The network diagram of Chinese cross-industry CBM\&As in 2000

Source: own elaboration in the Gephi program

27 A. Klimek [2016], op. cit., p. 147. 


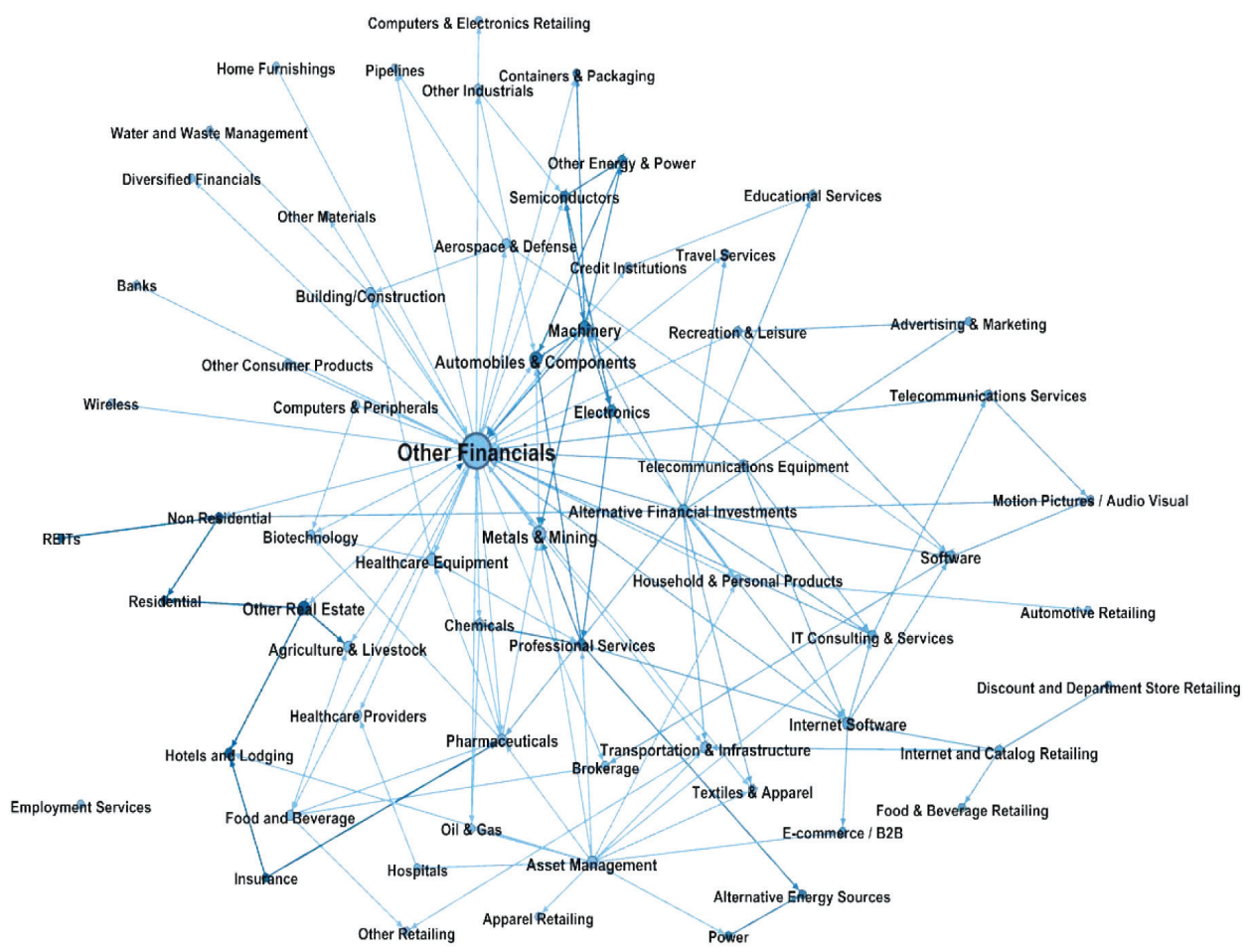

Figure 3.2. The network diagram of Chinese cross-industry CBM\&As in 2017

Source: own elaboration in the Gephi program

Table 3.2. Average values of basic statistics for Chinese CBM\&As networks in 2000-2017

\begin{tabular}{|c|c|c|c|c|c|c|}
\hline & 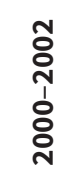 & 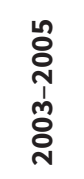 & 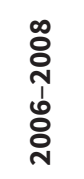 & 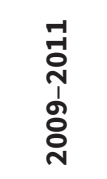 & 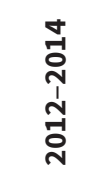 & 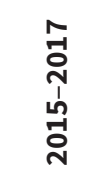 \\
\hline & 1 & 2 & 3 & 4 & 5 & 6 \\
\hline Network density (\%) & 7 & 6 & 6 & 6 & 6 & 8 \\
\hline Number of nodes & 25 & 29 & 81 & 53 & 55 & 65 \\
\hline Number of edges & 38 & 52 & 90 & 175 & 177 & 316 \\
\hline Number of cross-industry connections & 18 & 27 & 31 & 98 & 116 & 235 \\
\hline $\begin{array}{l}\text { Share of cross-industrial edges in total } \\
\text { connections (\%) }\end{array}$ & 47 & 55 & 52 & 56 & 65 & 74 \\
\hline $\begin{array}{l}\text { Value of CBM\&As transactions ( } \mathrm{mln} \\
\text { USD) }\end{array}$ & 1248 & 2934 & 8928 & 31012 & 29815 & 59001 \\
\hline
\end{tabular}


Table $3.2(\mathrm{~cd}$.

\begin{tabular}{|c|c|c|c|c|c|c|c|}
\hline & & & & & & \\
\hline & & 1 & 2 & 3 & 4 & 5 & 6 \\
\hline \multicolumn{2}{|c|}{$\begin{array}{l}\text { Number of countries in which Chinese } \\
\text { entities carried out CBM\&As }\end{array}$} & 11 & 16 & 36 & 39 & 39 & 48 \\
\hline \multirow{3}{*}{$\begin{array}{l}\text { Share of particular } \\
\text { forms of M\&As in the } \\
\text { structure of Chinese } \\
\text { capital outward } \\
\text { expansion }\end{array}$} & $\begin{array}{l}\text { Acquisition } \\
\text { of interests } \\
(\%)\end{array}$ & 38 & 33 & 33 & 38 & 36 & 33 \\
\hline & $\begin{array}{l}\text { Acquisition } \\
\text { of assets (\%) }\end{array}$ & 53 & 42 & 38 & 37 & 45 & 43 \\
\hline & Mergers (\%) & 9 & 24 & 29 & 25 & 19 & 23 \\
\hline
\end{tabular}

Source: own elaboration

Table 3.2. summarizes the overall results of the Chinese CBM\&As network analysis during the period 2000-2017. The examined network is characterized by relatively low density (not exceeding 10\%) over the entire analysed period. However, from the perspective of the directional nature and specificity of these transactions, this value is sufficient to carry out a more detailed analysis of individual nodes.

The data provided in table 3.2. shows the vast scale of overseas expansion of Chinese enterprises in the global market, since between 2000 and 2017 both the number of nodes and the edges in the considered CBM\&As network have significantly increased. This is also confirmed by the visualization presented in figure 3.1. and figure 3.2. Moreover, there has been a dynamic increase in the value of Chinese foreign investments since 2005. Between 2015 and 2017 the average value of Chinese CBM\&As was over 20 times higher than in the period 2003-2005.

In addition, it should be noted that during the considered period the share of M\&As by Chinese firms, which were involved in economically unrelated business activities (they belonged to different industries) in total mergers and acquisitions systematically improved. Between 2000 and 2002 conglomerate M\&As has represented on average about $47 \%$ of all CBM\&As transactions, while in the period 2015-2017 this percentage has increased to about 74\%. Therefore, it might be argued that Chinese companies not only have enlarged their presence on the international markets, but also diversified their activities in order to meet competition from foreign enterprises.

During the years 2000-2017 acquisitions of foreign entities were the dominant form of Chinese capital overseas expansion. Over the considered period, their share in the Chinese CBM\&As market represented on average $78 \%$. However, it is worth emphasizing that since 2002 the share of Chinese firms mergers with foreign enterprises has increased (table 3.2.). 
What is more, based on the data in table 3.2., it can be seen that Chinese companies have been constantly expanding their business activities to other countries. From the beginning of the $21^{\text {st }}$ century, the number of countries, in which CBM\&As were carried out by Chinese firms, has been steadily increasing. While in 2000 Chinese enterprises made investments in only 9 countries (including three non-Asian, i.e. Australia, Canada and the United States), in 2016 Chinese corporations entered the markets of 51 countries.

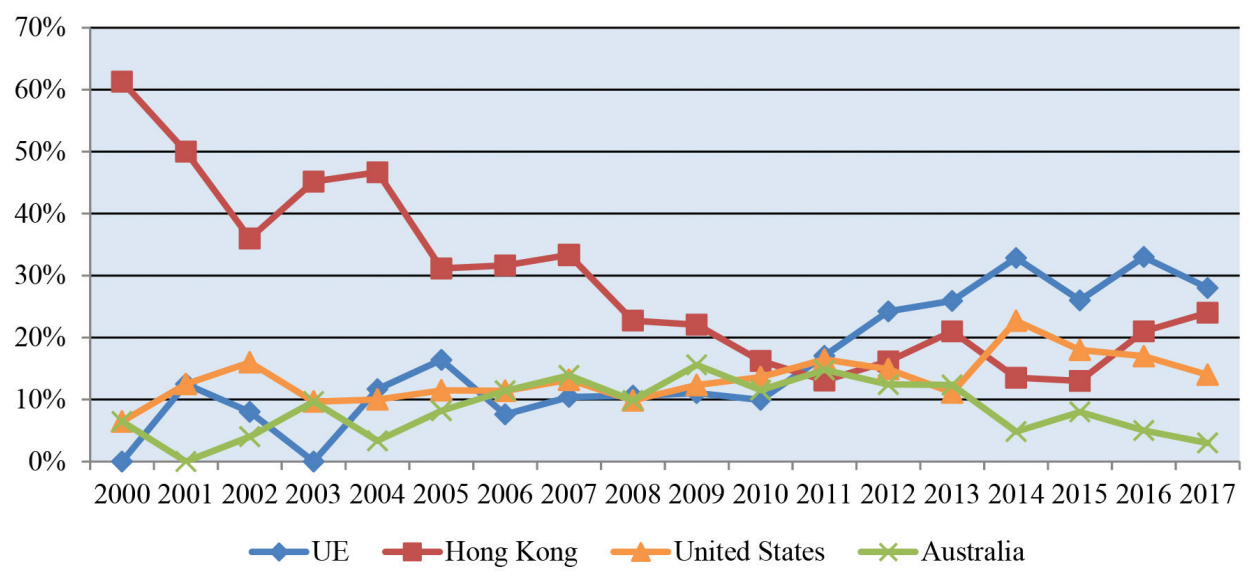

Figure 3.3. Main target regions of Chinese CBM\&As in 2000-2017 (percentage share)

Source: own elaboration

As the figure 3.3. shows, the main direction of Chinese CBM\&As was the Asian market until 2010. During 2000-2010 approximately 36\% of mergers and acquisitions were carried out in Hong Kong. However it was a downward trend. Since 2010 Chinese companies have increased their activity, among others, in the Member States of the European Union (EU) and the United States. In 2016, more than half of China's outward FDI in the EU was performed in the so-called Big Three, i.e. Germany, United Kingdom and France. ${ }^{28}$ These information might confirm that the implementation of 'Go Global' policy allowed the Chinese government to use foreign investment as a means of extending its political influence in strategic countries.

Throughout the entire considered period, the highest value of the degree centrality (figure 3.4.) was typically recorded in the sector of other financials (i.e. excluding banks and insurance institutions) and mining, and to a lesser extent in energy, machinery and automobiles sectors. Between 2000 and 2017, the largest number of CBM\&As have taken place in these sectors. Thus, from a global perspective, they are at the centre of the network since they maintain the majority of relationships with all entities participating in the system. ${ }^{29}$

28 E. Radomska [2018], op. cit., p. 88.

29 A. Sánchez Díez et al. [2017], op. cit., p. 60. 


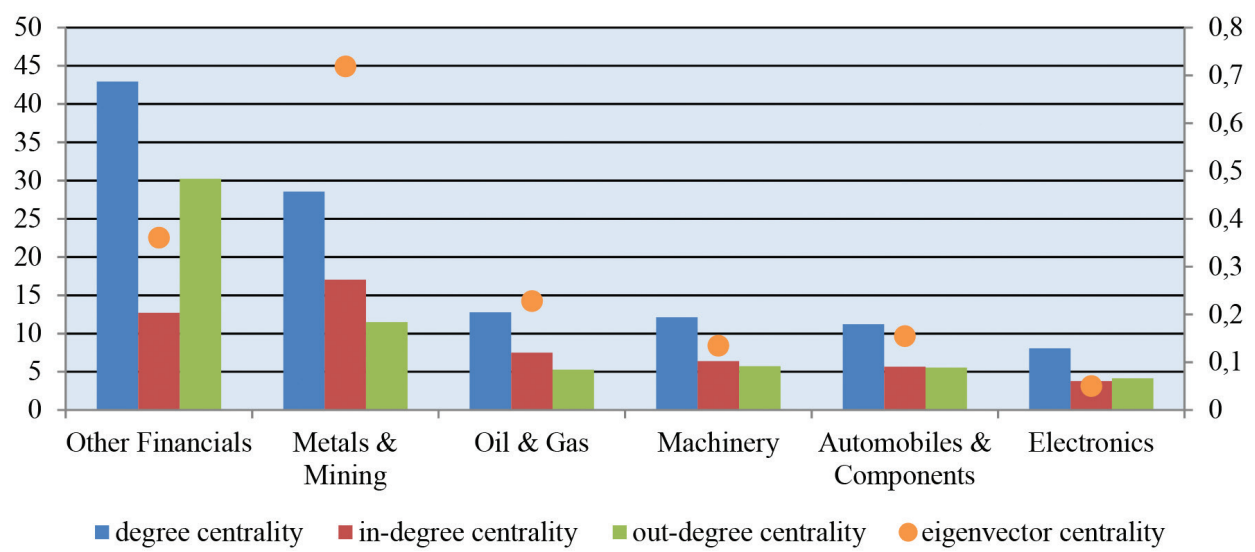

Figure 3.4. The average level of degree and eigenvector centrality for the main nodes forming the Chinese CBM\&As network in the period 2000-2017

Source: own elaboration

The assessment of the out-degree centrality shows that mainly Chinese companies which were assigned to the other financials business sector have expanded their activities through CBM\&As in the analysed period. In turn, based on the in-degree centrality, it can be stated that between 2000 and 2017 Chinese enterprises have located their activities abroad mainly in the metals and mining businesses, which was in line with the 'Go Global' strategy adopted by the Chinese government.

When analysing in detail the network presented in figure 3.1. and figure 3.2. with regard to the degree centrality of individual nodes, it can be noticed that there has been a change in the direction of Chinese FDI in 2017 compared to 2000. While in 2000, a lot of Chinese CBM\&As took place in other financials and IT sectors, in 2017 the largest number of cross-border connections occurred outside the other financial sector, i.e. in the metals and mining, machinery, automobiles and components sectors.

Additionally, between 2000 and 2017 the high average value of the eigenvector centrality (figure 3.4.) for the metals and mining and the other financials confirms that entities operating in these business sectors have occupied a flagship place in the examined CBM\&As network. The relatively high value of the prestige centrality also characterized machinery, automobiles and electronics. The indicated business sectors should be classified as key in the network in question, since they have obtained many connections with other entities holding important positions in the network.

In addition, during the period 2000-2017 the financial, IT, automobiles, electronics, energy, real estate and other consumer products sectors were characterized by a relatively high average closeness centrality (figure 3.5.). The level of this 
indicator signals that in the analysed period these nodes could reach other industries in the shortest possible time and occupy a relatively central position in the Chinese cross-industrial network CBM\&As. Therefore, it can be assumed that the indicated business sectors have belonged to the key investment directions of Chinese enterprises through conglomerate M\&As.

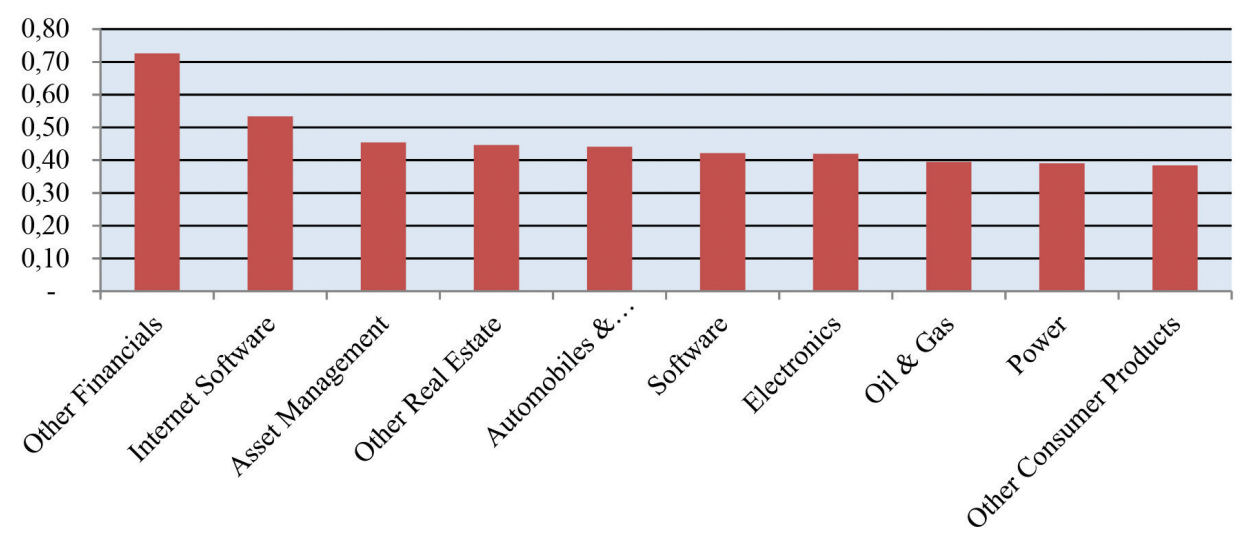

Figure 3.5. The average level of closeness centrality for the main nodes forming the Chinese CBM\&As network in the period 2000-2017

Source: own elaboration

\section{Conclusions}

To summarise, from the beginning of the $21^{\text {st }}$ century the share of Chinese companies in the global economy has increased significantly, which is mainly associated with a growing share in the FDI. They have aspired to be very active participants in the international mergers and acquisitions market. In particular, between 2000 and 2017:

- Chinese enterprises have significantly increased their investment activity in non-Asian countries;

- Chinese CBM\&As have showed a tendency to diversify their investment directions;

- Chinese companies from sectors of the other finance, energy, automobiles and electronics have played an important role in CBM\&As, they have occupied a central place in the examined network.

Conclusions of chapter 3 are connected with the changes that have taken place in the largest Asian transnational corporations, energy sector and banking sector. These issues are expanded in the chapter 2, chapter 4 and chapter 6 of this book. 
72 The social network analysis of Chinese cross-border mergers and acquisitions

The growing scale of CBM\&As carried out by Chinese entities has shown the PRC's efforts to develop and strengthen its position in the global market. The obtained results confirm that the outward direct investments have been one of the keystones of the Chinese government policy. It should be expected that in the near future China will strengthen its position as one of the largest foreign investors in the global economy. However, these issues require further in-depth research. 


\section{Chapter 4}

\section{The role of energy sector in the development of the Chinese economy}

\section{Tomasz Motowidlak*}

(iD) https://orcid.org/0000-0001-9948-4591

Energy consumption is an essential parameter of any economy's functioning. Research shows that there is a close relationship between energy demand and economic growth. This relationship is confirmed by, among others data on the average 3 -year growth of world real GDP ${ }^{1}$ and the demand for crude oil and primary energy in total in the world economy over the years 1972-2011 (figure 4.1.). Therefore, energy demand can be considered as one of the important determinants of economic growth. In particular, the level of electricity consumption, which the International Energy Agency (IEA) treats as "the fuel of the future", should be seen as such a determinant. ${ }^{2}$

Along with energy prices and the energy intensity of GDP, energy demand is also a significant determinant of the competitive position of the economy. Lower energy costs and lower energy intensity of GDP are instrumental in strengthening this position.

In the $21^{\text {st }}$ century, in addition to economic growth, climate change has become a significant factor influencing the pace of energy consumption. ${ }^{3}$ Large temperature

* University of Lodz, Department of International Business and Trade.

1 Based on a fixed USD value of 2005.

2 In 2018, global demand for energy increased by 2.3\%, and for electricity almost twice as much, i.e. by $4 \%$. Its consumption exceeded $23,000 \mathrm{TWh}$, which accounted for $1 / 5$ of global energy consumption, for: World energy outlook 2018 [2018], https://www.iea.org (accessed: 11.09.2019).

3 M. Skłodowska [2019], The appetite for electricity is growing. We can't keep up with production, https://www.money.pl (accessed: 30.03.2019). 
fluctuations and the resulting heat and cold waves engulfing various parts of the world imply an increase in energy demand for heating and air conditioning. The main reason for these changes are greenhouse gas emissions and industrial pollution associated with energy production and consumption processes, which are a source of ever-increasing external costs that further burden the economy.

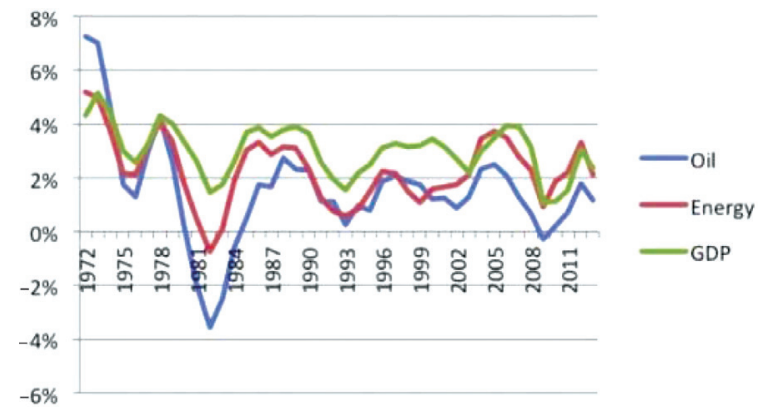

Figure 4.1. Word growth in oil, energy and GDP

Source: Main links between energy and the economy [2014], https://ziemianarozdrozu.pl (accessed: 20.09.2019)

Under these circumstances, energy policy of a given country, including the desired directions of energy sector transformation, has a large impact on the development pace and competitiveness of the economy. For many countries, the main goal of this transformation is to reduce $\mathrm{CO}_{2}$ emissions, which is intended to be achieved by reducing the use of fossil fuels and replacing them with renewable energy sources (RES). The high costs of such a change in the structure of energy production are, in the short and medium term, a major challenge for the economies of these countries.

\subsection{Primary energy consumption as a determinant of China's economic growth}

The scale of growth of the Chinese economy is illustrated by the volume and dynamics of its gross inland consumption of primary energy (GIC). Even in 2000, this country consumed 1,130 Mtoe of energy, which accounted for $11.6 \%$ of global consumption, giving way only to the USA and Europe (table 4.1.). These relations changed radically in 2010. The share of China's economy in global GIC increased then to $20.3 \%$, which meant that the country became the largest consumer of primary energy. During the years 2010-2018, this position was further strengthened. In this period, China's GIC increased by $24,8 \%$, which means 
that its dynamics was almost two times higher than the dynamics of global GIC growth. In 2018, China's economy consumed 3164 Mtoe of energy, thus increasing its share in global GIC to $22.6 \%$.

Table 4.1. Gross inland consumption of primary energy in 2000-2018

\begin{tabular}{|c|c|c|c|c|c|c|c|}
\hline \multirow{2}{*}{ Country/Region } & \multicolumn{2}{|c|}{2000} & \multicolumn{2}{|c|}{2010} & \multicolumn{2}{|c|}{2018} & \multirow{2}{*}{$\begin{array}{l}\text { Dynamics } \\
2018 / 2010\end{array}$} \\
\hline & Mtoe & $\%$ & Mtoe & $\%$ & Mtoe & $\%$ & \\
\hline Europe & 1.853 & 19.0 & 1.927 & 15.4 & 1.847 & 13.2 & 0.96 \\
\hline China & 1.130 & 11.6 & 2.536 & 20.3 & 3.164 & 22.6 & 1.25 \\
\hline India & 441 & 4.5 & 700 & 5.6 & 929 & 6.6 & 1.33 \\
\hline Japan\&Korea & 709 & 7.3 & 757 & 6.1 & 731 & 5.2 & 0.97 \\
\hline Russia & 619 & 6.4 & 688 & 5.5 & 800 & 5.7 & 1.16 \\
\hline USA & 2.269 & 23.3 & 2.218 & 17.7 & 2.258 & 16.2 & 1.02 \\
\hline Other & 2.725 & 28.0 & 3.685 & 29.5 & 4.249 & 30.4 & 1.15 \\
\hline Total & 9.746 & 100.0 & 12.511 & 100.0 & 13.978 & 100.0 & 1.12 \\
\hline
\end{tabular}

Source: own elaboration based on Global energy statistical yearbook 2019 [2019], https://yearbook.enerdata.net (accessed: 21.09.2019)

Gross inland consumption of primary energy of the USA and Europe was relatively stable over the period 2000-2018. As a result, the shares of this country and this continent in global GIC decreased in 2018 to $16.2 \%$ and $13.2 \%$ respectively. The corresponding shares of India, Russia, Japan and Korea, i.e. other leading global primary energy consumers, did not exceed 7\%. However, attention should be paid to the relatively high level of energy intensity of the Chinese economy, which weakens the dynamics of its growth. ${ }^{4}$ The lower energy intensity of US and European GDP is an important parameter for their economies, allowing them to partially offset China's advantage in terms of economic growth, which results from the higher growth rate of GIC.

High dynamics of economic growth and only small reserves of crude oil and gas mean that China imports more and more energy. ${ }^{5}$ In 2008-2018, its imports increased from 117 Mtoe to 689 Mtoe, resulting in an increase in the energy dependence of the Middle Kingdom from 5.2\% to 21.8\% (figure 4.2.). In 2018, China's

4 In 2019, China used 3 kWh of primary energy to produce a GDP of 1 USD, while Germany, France and Japan - $1 \mathrm{kWh}$, the USA - $1.3 \mathrm{kWh}$, and Poland $2 \mathrm{kWh}$, for: A Pole produces less for more - from where such energy consumption? [2018], https://wysokienapiecie.pl (accessed: 08.08.2018).

5 Ł. Gacek [2012], China’s energy security, Księgarnia Akademicka, Kraków, p. 23. 
oil and gas import dependency ratios reached $70 \%$ and $43 \%$ respectively, ${ }^{6}$ which was the result of importing 449 Mtoe and 104 Mtoe of these raw materials, respectively. ${ }^{7}$ The value of the corresponding indicator for coal in 2018 was 7\%, which translates to import volume of 136 Mtoe. $^{8}$

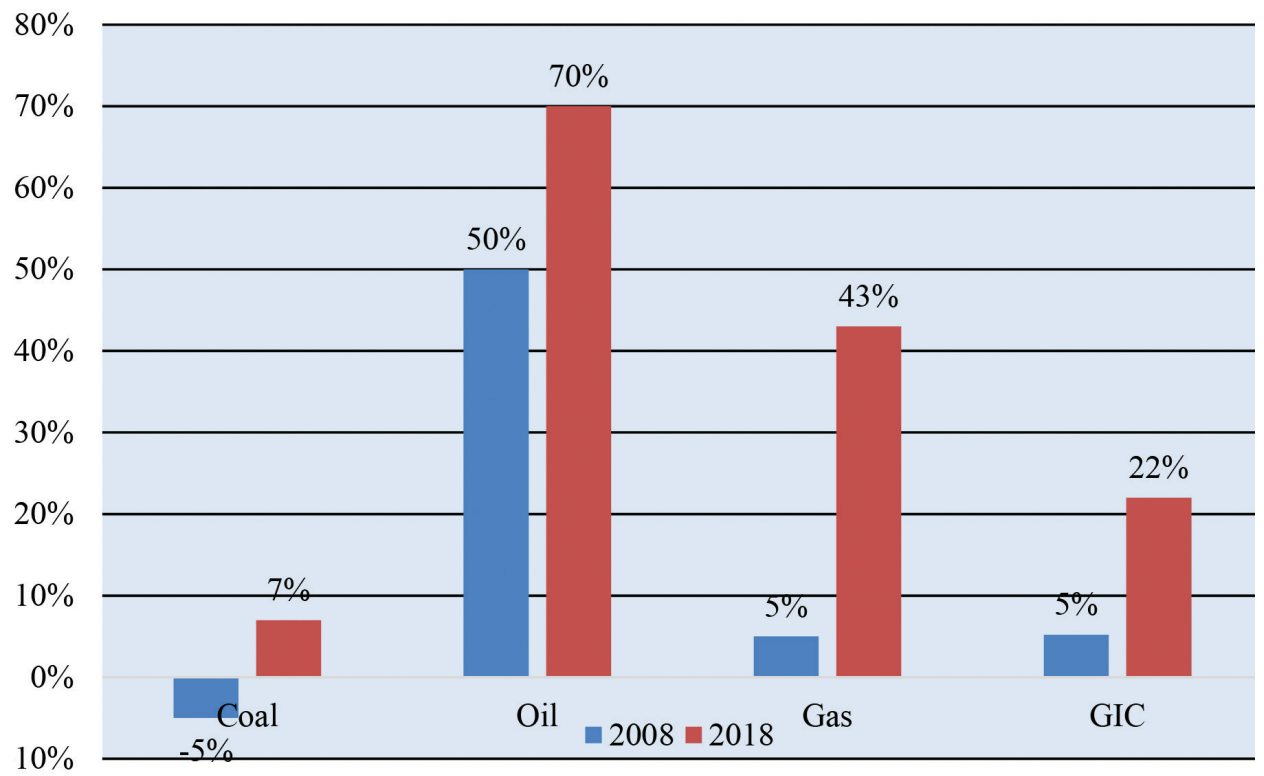

Figure 4.2. China's energy dependence 2008-2018

Source: own elaboration based on BP Statistical Review of World Energy 2019 [2019], https://www.bp.com (accessed: 30.09.2019)

Growing imports make China a significant participant in its global market, which has a major impact on energy prices. The amount of crude oil imported in 2018 by the Middle Kingdom amounted to a $20.5 \%$ share in the global market for this raw material on the import side (table 4.2.). In this respect China's consumption was only second to Europe, whose corresponding share was $22.9 \%$. China's share in global LNG gas imports was $17.2 \%$ and was only lower than the analogous parameter in Japan. After taking into account gas supplies carried out using onshore transmission infrastructure, the Middle Kingdom was the second (after

6 China: Growing import volumes of LNG highlight China's rising energy import dependency [2019], The Oxford Institute for Energy Studies, https://www.oxfordenergy.org (accessed: 24.06.2019), p. 2.

7 Back in 2008, China imported 193 Mtoe crude oil and 4 Mtoe gas, which met respectively 50\% and $5 \%$ of domestic demand for these raw materials.

8 Even in 2008, China was a net exporter of coal, selling it in the amount of 80 Mtoe. 
Europe) gas importer in the world. ${ }^{9}$ These supplies, largely from Turkmenistan, accounted for $6 \%$ of global pipeline supplies in $2018 .^{10}$ Despite significant coal reserves, China has become its major importer. In 2018, its share in the global import of this raw material was $17.1 \%$.

Table. 4.2. Oil, gas and coal net imports

\begin{tabular}{|l|c|c|c|c|}
\hline Country/Region & Oil (\%) & $\begin{array}{c}\text { Gas } \\
\text { LNG (\%) }\end{array}$ & $\begin{array}{c}\text { Gas } \\
\text { by pipeline (\%) }\end{array}$ & Coal (\%) \\
\hline Europe & 22.9 & 16.7 & 59.5 & 17.5 \\
\hline China & 20.5 & 17.2 & 6.0 & 17.1 \\
\hline India & 10.1 & 7.2 & 0.0 & 16.5 \\
\hline Japan & 6.7 & 26.2 & 0.0 & 14.0 \\
\hline Korea & 5.7 & 13.9 & 0.0 & 10.8 \\
\hline USA & 17.1 & 0.0 & 9.6 & 0.3 \\
\hline Other & 17.0 & 18.8 & 25.0 & 23.7 \\
\hline Total & 100.0 & 100.0 & 100.0 & 100.0 \\
\hline
\end{tabular}

Source: own elaboration based on: BP Statistical Review of World Energy 2019 [2019], https://www.bp.com (accessed: 30.09.2019)

\subsection{Electricity consumption as a determinant of the development of China's economy}

Outlined by the dynamics of GIC, the picture of China's economic growth is enriched by indicators related to electricity consumption. Electricity is the most valuable form of secondary energy and its production and transmission constitutes an economic bloodstream of every country which, next to the transport system, determines the efficient functioning of the economy. It is used to power many devices used, among others, in industry, communication, agriculture and many other

9 Will the Chinese harm the diversification of gas supplies to Poland? [2019], https://www. energetyka24.com (accessed: 27.02.2019).

10 According to the IEA sustainable scenario, China's demand for natural gas is expected to grow steadily by about $5 \%$ per year to reach over 600 billion $\mathrm{m}^{3}$ in 2040 . This country will thus become the second, after the US, gas market in the world, for: The role of gas in today's energy transitions [2019], IEA, https://webstore.iea.org (accessed: 15.06.2019). 
branches. Electricity is also necessary for the development and implementation of new technological solutions in the economy, which allows it to improve its competitiveness. $^{11}$

It should be emphasised that the very production and transmission of electricity is associated with the use of advanced technologies. It is thanks to the energy industry that different areas of modern technology are developing: electronics, IT, terrestrial and satellite communications. The computer and telephone networks are expanding. Therefore, the consumption of electricity not only indicates the economic growth of a given country, but also constitutes an important indicator of its economic development.

In 2000, China consumed 1368 TWh of electricity, which constituted almost 9\% of its global consumption (table 4.3.). Chinese economy was significantly behind in this respect when compared to the developed economies of the USA, Europe, Japan and Korea, whose share in this consumption constituted $26.1 \%, 23.6 \%$ and $14.8 \%$ respectively. The dynamic development of China's economy meant that already in 2010 it consumed a comparable amount of electricity. In 2017, electricity consumption in the Middle Kingdom reached 6,594 TWh, which accounted for almost $26 \%$ of its global consumption. ${ }^{12}$ China has thus become the largest electricity consumer in the world.

Table 4.3. Electricity consumption $2000-2017$ and its forecast until 2030

\begin{tabular}{|l|r|r|r|r|r|r|r|r|}
\hline \multirow{2}{*}{ Country/Region } & \multicolumn{2}{|c|}{2000} & \multicolumn{2}{c|}{2010} & \multicolumn{2}{c|}{2017} & \multicolumn{2}{c|}{2030} \\
\cline { 2 - 10 } & \multicolumn{1}{|c|}{ TWh } & \multicolumn{1}{c|}{$\%$} & \multicolumn{1}{c|}{ TWh } & \multicolumn{1}{c|}{$\%$} & \multicolumn{1}{c|}{ TWh } & $\%$ & TWh & $\%$ \\
\hline Europe & 3.621 & 23.6 & 4.083 & 19.1 & 4.137 & 16.2 & 4.417 & 13.3 \\
\hline China & 1.368 & 8.9 & 4.190 & 19.6 & 6.594 & 25.8 & 9.530 & 28.6 \\
\hline India & 553 & 3.6 & 980 & 4.6 & 1.604 & 6.3 & 3.099 & 9.3 \\
\hline Japan\&Korea & 2.266 & 14.8 & 3.020 & 14.1 & 3.372 & 13.2 & 4.406 & 13.2 \\
\hline Russia & 709 & 4.6 & 851 & 4.0 & 915 & 3.6 & - & - \\
\hline USA & 4.002 & 26.1 & 4.330 & 20.3 & 4.194 & 16.4 & 4.440 & 13.3 \\
\hline Other & 2.820 & 18.4 & 3.920 & 18.3 & 4.737 & 18.5 & 7.386 & 22.2 \\
\hline Total & 15.339 & 100.0 & 21.374 & 100.0 & 25.553 & 100.0 & 33.278 & 100.0 \\
\hline
\end{tabular}

Source: own elaboration based on Global energy statistical yearbook 2019 [2019], op. cit., and World energy outlook 2018 [2018], https://www.iea.org (accessed: 11.09.2019)

11 China is making currently little contribution to the development of global technology. Currently, about $70 \%$ of new technologies come from Western countries or Japan.

12 In 2018, China's share in global electricity consumption increased to $26.9 \%$. 
IEA forecasts indicate that China will be strengthening its position in the next decade. The high dynamics of the Chinese economy's development will cause its consumption to account for $28.6 \%$ of global electricity, i.e. more than the European and US economies combined. The dynamic increase in electricity consumption by China will translate into a significant improvement in economic growth rates. According to Business Center Club forecasts, by 2050 this country will reach about $60 \%$ of GDP per capita of US. ${ }^{13}$ Due to the huge population in 30 years, China will definitely become the first economy in the world, because although the average GDP per capita will remain lower than in the US or the EU, ${ }^{14}$ the GDP of the entire country will correspond to the GDP level of the EU and USA combined. ${ }^{15}$

\subsection{Side effects of China's economic growth}

In the period 1985-2005, economic growth was the main priority of the Chinese economy, which meant that environmental protection and the harmful effects of electricity generation and industrial production on the environment were of secondary importance. ${ }^{16}$ It was growth, which in terms of the environment and natural resources could be called robbery. It led to huge pollution of air, water and soils, threatening human health and life. ${ }^{17}$ While in 1990 China emitted 2261 million tons of $\mathrm{CO}_{2}$, which constituted "only" $11.2 \%$ of global emissions of this greenhouse gas (table 4.4.), in 2007 they overtook the USA and Europe in the classification of its largest emitters on the globe.

In 2010, China's share in global $\mathrm{CO}_{2}$ emissions increased to 26.0\%, and in 2018 to $28.8 \%$, which was the result of the emission of 9467 million tonnes of $\mathrm{CO}_{2}$, i.e. more than 4 times increase over the period 1990-2018. What's more, specialists - including Chinese - believe that maintaining current trends may mean that in 2030 the Middle Kingdom will emit more $\mathrm{CO}_{2}$ than the whole world combined. ${ }^{18}$ This scenario is quite realistic because the peak in $\mathrm{CO}_{2}$ emissions announced by China is expected to occur around 2030. Realisation of this scenario means a significant burden to the global climate and a major contribution towards increasing the average global temperature by more than $2^{\circ} \mathrm{C}$.

13 At this level, catching up with the most developed countries will fade away, as has happened in Japan, which currently generates $75 \%$ of GDP per capita in the USA.

14 It is estimated that in 2050 the population of China will be almost twice as high as the US and EU combined.

15 In search of lost power. China from a poor country has become a global superpower [2019], https://forsal.pl (accessed: 22.04.2019).

16 China - a challenge for the world? [2015], http://www.chronmyklimat.pl (accessed: 22.07.2019).

17 Ł. Gacek [2015], Green energy in China, Wydawnictwo Uniwersytetu Jagielońskiego, Kraków, p. 57.

18 B. Góralczyk [2019], China's energy geostrategy, https://www.cire.pl (accessed: 26.09.2019). 
Table 4.4. $\mathrm{CO}_{2}$-emissions of China 2000-2017 and their forecast until 2030

\begin{tabular}{|c|c|c|c|c|c|c|c|c|c|}
\hline \multirow{2}{*}{$\begin{array}{c}\text { Country/ } \\
\text { Region }\end{array}$} & \multicolumn{2}{|c|}{1990} & \multicolumn{2}{|c|}{2000} & \multicolumn{2}{|c|}{2010} & \multicolumn{2}{|c|}{2018} & \multirow{2}{*}{$\begin{array}{l}\text { Dynamics } \\
2018 / 1990\end{array}$} \\
\hline & $m \ln t$ & $\%$ & $m \ln t$ & $\%$ & $m \ln t$ & $\%$ & $m \ln t$ & $\%$ & \\
\hline Europe & 4.424 & 21.8 & 4.263 & 18.7 & 4.178 & 14.0 & 3.839 & 11.7 & 0.87 \\
\hline Canada & 430 & 2.1 & 529 & 2.3 & 548 & 1.8 & 596 & 1.8 & 1.39 \\
\hline China & 2.261 & 11.1 & 3.144 & 13.8 & 7.763 & 26.0 & 9.467 & 28.8 & 4.19 \\
\hline India & 522 & 2.6 & 908 & 4.0 & 1.575 & 5.3 & 2.277 & 6.9 & 4.36 \\
\hline Japan & 1.049 & 5.2 & 1.134 & 5.0 & 1.100 & 3.7 & 1.123 & 3.4 & 1.07 \\
\hline USA & 4.851 & 23.9 & 5.809 & 25.4 & 5.430 & 18.2 & 5.118 & 15.5 & 1.06 \\
\hline Other & 6.776 & 33.4 & 7.050 & 30.9 & 9.257 & 31.0 & 10.496 & 31.9 & 1.55 \\
\hline Total & 20.313 & 100.0 & 22.837 & 100.0 & 29.851 & 100.0 & 32.916 & 100.0 & 1.62 \\
\hline
\end{tabular}

Source: own elaboration based on Global energy statistical yearbook 2019 [2019], op. cit., and World energy outlook 2018 [2018], https://www.iea.org (accessed: 11.09.2019)

\subsection{Fuel conditioning of electricity generation in China}

The side effects of China's dynamic economic growth are largely a consequence of the hard coal-based electricity sector. This high-emission raw material dominated the structure of electricity generation in this country. In the first decade of the $21^{\text {st }}$ century, the share of coal in this structure was about $80 \%$. In the years 2000-2010, this share decreased by only 1 p.p..$^{19}$ (Table 4.5.). The use of coal for electricity generation in China is related to its significant resources in this country, which are estimated at around $14 \%$ of global resources and are second only to the USA and Russia, and which translate into relatively low costs. ${ }^{20} \mathrm{CO}_{2}$ emissions related to the structure of electricity generation, are further compounded by the relatively high energy intensity of China's economy.

19 During this period, China also reduced by 3.1 p.p. the share of crude oil in the electricity generation structure. Instead by 1.8 p.p. increased the share of nuclear energy, by 0.9 p.p. of gas, by 0.7 p.p. by biomass and by 0.8 p.p. of hydropower in this structure.

20 China is the main producer of coal in the world, controlling almost half of its production. 
Table 4.5. Fuel structure of electricity generation in China $2000-2017$ and its forecast until 2030

\begin{tabular}{|l|r|r|r|r|}
\hline \multicolumn{1}{|c|}{ Fuel } & $\mathbf{2 0 0 0}$ & $\mathbf{2 0 1 0}$ & $\mathbf{2 0 1 7}$ & $\mathbf{2 0 3 0}$ \\
\hline Coal (\%) & 78.9 & 77.9 & 67.4 & 49.2 \\
\hline Gas (\%) & 1.3 & 2.2 & 3.3 & 7.6 \\
\hline Oil (\%) & 3.4 & 0.4 & 0.2 & 0.1 \\
\hline Nuclear (\%) & 0.0 & 1.8 & 3.8 & 7.9 \\
\hline Bioenergy (\%) & 0.1 & 0.8 & 1.4 & 2.7 \\
\hline Hydro (\%) & 16.2 & 17.0 & 17.7 & 14.6 \\
\hline Wind (\%) & 0.0 & 0.0 & 4.3 & 9.4 \\
\hline PV (\%) & 0.0 & 0.0 & 1.9 & 8.3 \\
\hline Geothermal (\%) & 0.0 & 0.0 & 0.0 & 0.3 \\
\hline Total (\%) & 100.0 & 100.0 & 100.0 & 100.0 \\
\hline
\end{tabular}

Source: own elaboration based on World energy outlook 2018 [2018], https://www.iea.org (accessed: 11.09.2019)

Significant changes in the structure of China's electricity production occurred in the second decade of the $21^{\text {st }}$ century. In 2017, a decrease of 10.5 p.p. of coal share in this structure was recorded. Correspondingly, there was a clear trend towards the use of low-carbon sources of electricity generation, among which RES became the most significant. The total share of RES (i.e. hydro, solar and wind energy) in the electricity generation structure was $25.3 \%$. Although hydroelectric power (already previously used) had a decisive influence on this share, accounting for $17.7 \%$ of the electricity generation, this means an increase of 0.7 p.p. in the period 2010-2017.

The share of wind energy (4.3\%) as well as photovoltaic energy (1.9\%) and biomass $(1.4 \%)$ have become significant. The importance of low-carbon sources in China's electricity generation structure has also increased due to greater use of nuclear and gas energy. In the period 2010-2017 the share of nuclear energy in this structure increased to $3.8 \%$, i.e. by 2 p.p., and gas share to $3.3 \%$, i.e. by 1.1 p.p.

IEA forecasts point to a further reduction of the role of coal in China's electricity generation in the next decade. In 2030, its share in the electricity generation structure will not exceed $50 \%$. The share of RES in this structure will increase to $35.3 \%$, to which hydropower will still contribute the most. However, its share will amount to $14.6 \%$, which means it will be 3.1 p.p. lower than in 2017 . The mentioned forecasts predict that the dynamics of RES growth will be much higher. The share of wind energy in the electricity generation structure will increase to $9.4 \%$, and solar energy up to $8.3 \%$. Geothermal energy will appear, with a $0.3 \%$ share in this structure. 


\subsection{New priorities in China's power industry}

Limiting the role of coal and the development of RES in the energy sector are the result of a thorough change in the development model of China's economy. Economic expansion, resulting in an increase in electricity production, which has increased 10 -fold over 10 years, mainly by burning coal, has become the cause of progressive environmental degradation. Already in 2004, problems related to environmental pollution costed China over USD 200 billion, which means that ecological damage absorbed about $10 \%$ of the country's GDP. ${ }^{21}$ World Bank analyses have shown that in 2003 health costs in China resulting from air and water pollution amounted to RMB 362 billion, or $2.68 \%$ of GDP. Air pollution caused premature death of 358,000 people in 600 Chinese cities every year. In 2010, the dynamics of costs generated by pollution amounted to $13.7 \%$ and was by 3.3 p.p. higher than GDP growth dynamics. At the same time, this year the amount of RMB 558.9 needed for the utilization of pollution was as much as $94 \%$ higher than the amount spent for this purpose in 2004. ${ }^{22}$

The problems of environmental pollution have prompted the Chinese authorities to move away from the current model of economic expansion towards a sustainable economy based on internal consumption. It can be assumed that strategic decisions regarding this change were made during the Third Plenum of the Central Committee of the Communist Party of China in November 2013. The adopted documents referred directly to the transition to a "green" and even "carbon-free" economy in which energy is of paramount importance and is an integral component of a coherent and far-reaching state development strategy. The importance of the energy policy in this strategy is evidenced by the establishment of the National Energy Administration in 2008, which in January 2010 was transformed into the supra-ministerial National Energy Commission headed by the prime minister. In 2007, the first National Action Plan for Climate Change was adopted, and the second was approved in $2012 .{ }^{23}$ It is in them, and in the assumptions of the twelfth 5-year plan for 2011-2015, where the goals of moving away from coal based energy and of the gradual transition to alternative sources were defined for the first time.

21 These data do not include additional costs for damage to health or death.

22 Ł. Gacek [2015], op. cit., p. 83.

23 K. Pająk, J. Mazurkiewicz, P. Lis [2015], China's Road to a Low Carbon Economy, in: J. Marszałek-Kanwa, K. Pająk (eds.), Energy Policy of Asia-Pacific States, Wydawnictwo Adam Marszałek, Toruń, p. 184. 


\subsection{Development of technologies and innovative solutions in China's power industry}

In addition to changing the fuel structure of electricity generation to reduce its emissions, a strategy for improving energy efficiency ${ }^{24}$ and smart and sustainable development activities have become a key element of China's energy policy. The economic growth of the Middle Kingdom is to be based on effective investments in research and development of technologies and innovative solutions, ${ }^{25}$ in particular in electricity, which is crucial for its economy and authorities.

The actions taken thus far are focused on the development of innovative technologies for electricity generation and energy-saving, environmentally friendly technologies. This is facilitated by capital expansion in Europe, concentrating on taking over technologies and organizational solutions in the energy sector. The long-term effect is to increase China's energy security while providing new impulses for the development of Chinese industry. The effects of scale should also be taken into account because the Chinese economy is comparable to the European, American and partly Asian economies taken together, so even a small change in this country will have global consequences.

Investments in RES became an important element in the development of China's economy. ${ }^{26}$ Energy is and will permanently be a key factor in this development. In connection with this, the changes taking place in China's energy-related operations significantly affect energy security and the quality of social life. ${ }^{27}$ RES are not only more and more profitable and (despite less support) are starting to compete on the market with traditional technologies, but they are driving progress and innovation. Their further development, in connection with works on improvement of energy storage devices and systems (carried out in China on large scale $)^{28}$ may remove one of the main obstacles to the promotion of RES, i.e. their instability.

Already in 2010, China became the world's largest investor in RES sector, allocating USD 45 billion to its development, while the second, Germany - USD 41.2 billion and the third, USA - USD 34 billion. It is estimated that even then the Middle Kingdom was responsible for about half of the global production of both photovoltaic

24 China has made tremendous progress in energy efficiency. Without the effects of its improvement introduced since 2000 , the country would consume $12 \%$ more energy in 2017 , which would entail an additional 1.2 Gt CO2 emissions, corresponding to half of US emissions, for: Energy efficiency 2018 [2018], IEA, https : //www.iea.org (accessed: 24.07.2019), p. 145.

25 In 2020, China intends to spend $2.5 \%$ of GDP on innovation.

26 Prospects for distributed energy systems in China [2017], IEA, https://www.iea.org (accessed: 19.09.2019), p. 44.

27 R. Nowakowski [2019], Sustainable energy transformation in Poland, or how can conventional sources support the rapid development of renewable energy?, "Polish Energy Brief", vol. 2.

28 Intensive work on integrating energy storage with energy networks is underway in almost all developed countries, especially in Germany, China and the USA. 
cells and wind turbines. In 2018 alone, $44 \mathrm{GW}$ of photovoltaic power and $20 \mathrm{GW}$ of wind power were installed in China. ${ }^{29}$

According to Bloomberg New Energy Finance, China's total investments in clean energy technologies amounted to USD 132.6 billion in 2017 (these expenditures increased by $24 \%$ compared to the previous year) and accounted for approx. $40 \%$ of global expenditure for this purpose ${ }^{30}$ (figure 4.3.). China dominates both in terms of investment volume and global production. ${ }^{31}$ Its share in global production of photovoltaic cells increased in 2017 to about $60 \%$, while USA's and Canada's share was only about $6 \% .{ }^{32}$ US investment outlays for clean energy technologies in 2017 amounted to USD 56.9 billion (an increase of 1\%), i.e. less than half of the value of Chinese investments. Germany (USD 14.6 billion, an increase of 26\%) and Great Britain (USD 10.3 billion, an increase of 56\%) allocated significantly less to the development of these technologies.

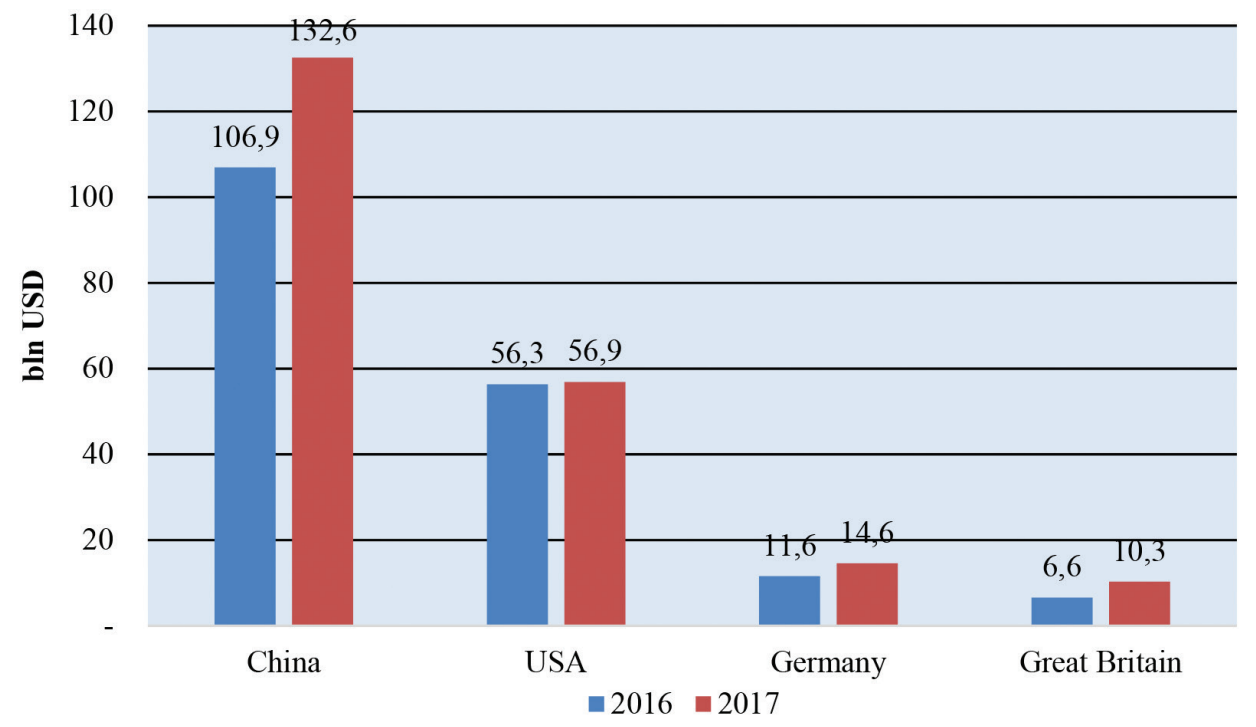

Figure 4.3. Investments in clean energy technologies

Source: own elaboration based on Clean energy investment trends [2018], Bloomberg New Energy Finance, https://data.bloomberglp.com (accessed: 16.01.2018)

29 China power system transformation. Assessing the benefit of optimised operations and advanced flexibility options [2019], International Energy Agency, https://webstore.iea.org (accessed: 14.10.2019), p. 7.

30 Clean Energy investment trends [2018], Bloomberg New Energy Finance, https://data. bloomberglp.com (accessed: 16.04.2019), p. 12.

31 In 2016, five of the six largest solar cell manufacturers came from China, for: China's global renewable expansion [2017], Institute for Energy Economics and Financial Analysis, http:// ieefa.org (accessed: 21.10.2019), p. 2.

32 M. Wasiński [2018], Prospects for the development of renewable energy sources in the USA, https://www.cire.pl (accessed: 21.07.2019). 
IEA predicts that by 2030 Chinese nuclear power will be $150 \mathrm{GW}$. The Middle Kingdom will thus overtake USA in terms of its capacity, becoming the largest nuclear energy producer in the world. ${ }^{33}$ Nuclear power is to be an instrument reducing air pollution in the country. In 2018, approximately 60 nuclear blocks were built, of which over a third in China. The IEA indicates that by 2040 the share of installed capacity in nuclear energy in China's energy mix will be $4 \%$ compared to $2 \%$ in $2016 .^{34}$

The development of nuclear power in China contrasts with its decline in the US and Europe, mainly in Germany and France. In the US, the closure of eight obsolete nuclear blocks has been announced, support plans have been discarted, and the lifetime of other installations has been shortened. Germany's energy policy assumes the shutdown of all nuclear power plants by 2022, while the decline in nuclear generation is noted by France, which is the leader in the region in terms of generating electricity from the atom.

According to the IEA opinion, the closure of nuclear power plants in Europe and North America threatens global plans to reduce $\mathrm{CO}_{2}$ emissions, unless new installations of this type are created or the use of RES increases. Nuclear power is currently the largest low-emission source of electricity generation on these continents, and the capacity installed in it is almost three times greater than the total power of wind turbines and solar cells. ${ }^{35}$

\subsection{China's capital expansion as a form of acquiring modern energy technologies}

China's capital expansion towards Europe that was launched after 2010 is to serve the search for new solutions and modern technologies and management methods in the power industry. ${ }^{36}$ Mergers and acquisitions have become the main object of interest for investors from the Middle Kingdom replacing the previously preferred greenfield investments. It should be remembered that among these investors there are the largest companies and state-market conglomerates of China, belonging to the world's richest fuel and energy concerns. They include CNPC (China

33 In 2018, 33 reactors were operated in China with a total capacity of $28.97 \mathrm{GW}$.

34 IEA: China can be a leader in the construction of nuclear power plants [2018], https://www.cire. pl (accessed: 23.06.2019).

35 IEA: the closure of nuclear power plants threatens global plans to reduce $\mathrm{CO}_{2}$ emissions [2017], https://www.cire.pl (accessed: 23.09.2019).

36 In earlier years, this expansion focused on the areas of Africa and Latin America and its main goal was the search for raw materials. 
National Petroleum Corporation), CNOOC (China National Oil Offshore Corporation), Sinopec, as well as solar cell manufacturers (e.g. Yingli, Suntech) and wind turbines (Sinovel, Goldwind).

Shares in network companies and energy producers of European countries acquired in recent years by Chinese entities, are to serve the modernization of Chinas power system. These entities have already become co-owners of transmission system operators (TSO) in Belgium, Greece, Portugal and Italy as well as power plants in Portugal and Great Britain. ${ }^{37}$

China's growing capital expansion has been a cause of concern in Germany since the takeover of Kuka - the leader of German robotics - in 2016. ${ }^{38}$ This is why the initial agreement of February 2018 on the conditions for the sale of half of the $40 \%$ shares of the 50 Hertz TSO belonging to the Australian IFM fund to the Chinese state company SGCC ${ }^{39}$ (State Grid Corporation of China) caused a great deal of concern. ${ }^{40}$ SGCC's goal was to transfer technologies related to the management of networks in which $53 \%$ of electricity comes from unconventional sources. By frustrating this transfer, German government has sent a strong political signal that it was interested in protecting critical energy infrastructure. This signal was all the more significant because it was sent at a time of high penetration by Chinese investors searching for takeover opportunities in companies pushing technical progress and in industries of strategic importance to Germany and other European countries. ${ }^{41}$

\section{Conclusions}

The high growth dynamics and the achieved stage of development of the Chinese economy require an appropriate energy strategy. One of the main determinants of maintaining this dynamics, which determines the possibility of implementing large investments and installing further air conditioners, washing machines and refrigerators in Chinese apartments, is to meet the growing demand for electricity, which forces the construction of new power plants. At first, this demand was met

37 K. Popławski [2019], Chinese in German energy networks?, https://www.osw.waw.pl (accessed: 21.02.2019).

38 The German government opposed this takeover. However, German regulations do not protect against taking over technology companies, but also companies of strategic importance.

39 SGCC owns most of China's power grid.

40 Energy is one of the 10 strategic areas in which China wants to become a leader by 2025 and will compete for this position, among others with Germany.

41 In Germany, the purchase by the Chinese of shares in the TSO of energy was thwarted [2018], https://www.cire.pl (accessed: 27.09.2019). 
by coal, side effect of the combustion of which, both by the energy sector and by Chinese industry, was pollution and lack of emission and waste control.

At one point, it turned out that China can produce cheaply and increase the competitiveness of its economy, but this was at the expense of significant deterioration of the environment and, as a consequence, the standard of living of the citizens. Therefore, for China, the introduction of low-carbon forms of energy production has become a real necessity to save the lives of citizens. Hence, the shift towards the development of RES, but also nuclear energy.

Energy demand is one of the important measures of the position and dynamics of China's economy in the world. Satisfying it by the increasing use of low-carbon (generally innovative) technologies creates jobs and promotes the implementation of innovative solutions. In addition to government consumption expenditure, as presented in Chapter 5, the use of innovative technologies and solutions in the energy sector is one of the important determinants of China's GDP. Some of these solutions are obtained as a result of mergers and acquisitions of energy companies, mainly in Europe (Chapter 4 has been devoted to the role of mergers and acquisitions in the Chinese economy). An important incentive for the innovative development of China's economy are the rich resources of rare metals, without which the creation of modern energy technologies is not possible. The Middle Kingdom controls $90 \%$ of the rare metal mining sector and $72 \%$ of the processing sector. 



\title{
Chapter 5
}

\section{The comparative analysis for gross domestic product of China and ASEAN member states}

\author{
Agnieszka Matuszewska-Pierzynka*
}

(iD) https://orcid.org/0000-0003-1119-6347

In spite of the fact that China's economy currently is the world's second-largest economy, it also decelerated in the year 2008 when the global financial crisis began. The gross domestic product (GDP) growth slowed down primarily as a result of the reduction in trade surplus - the contribution of net exports to GDP growth significantly decreased and thereafter remained at zero or negative level. In order to maintain the target GDP growth, the Chinese government responded to the global financial crisis by implementing a wide and expensive economic package ${ }^{1}$ that provided various incentives for domestic demand. ${ }^{2}$ Since that time, the Chinese economic growth was mainly caused by investment rather than exports - the contribution of gross capital formation to GDP growth rapidly increased in the year 2009 to above $85 \%{ }^{3}$ The average growth rate of real GDP in China declined from $14.2 \%$ in 2007 to $9.6 \%$ in 2008 and next, to $9.2 \%$ in 2009. After the implementation of economic package counteracting the distortions due to the global financial crisis,

\footnotetext{
University of Lodz, Department of International Business and Trade.

1 The implementation of a massive stimulus program as a response to the global financial crisis, aimed at an increase in investments that were to be financed by bank loans and credits resulted in a very high level of post-crisis credit to GDP ratio. See: World Bank [2017], China - Systematic Country Diagnosis: towards a more inclusive and sustainable development, World Bank Group, Washington, D.C., p. 5.

2 W.M. Morrison [2014], China's economic rise: history, trends, challenges and implications for the United States, Congressional Research Service, Washington, D.C., p. 3.

3 C. Fang [2016], China's economic growth prospects from demographic dividend to reform dividend, E. Elgar Publishing, Cheltenham (UK), Northampton (MA, USA), pp. 129, 131.
} 
China's economic growth in 2009 was lower than in the previous years but this fall was not as sharp as in 2008. In 2010 the growth rate of real GDP rose to $10.4 \%$ and in 2011 it fell back to $9.2 \%{ }^{4}$ so therefore, the average real GDP growth in China in the period 2009-2011 was equal to 9.6\%. Unfortunately, in 2012 and 2013 the growth rate of real GDP dropped to $7.7 \%$, suggesting that China's economy started slowing down again. ${ }^{5}$ After the year 2011 the contribution of final consumption, which included both household and government consumption to real GDP growth decreased - the contribution to real GDP growth of government consumption was relatively steady but of the household consumption declined. ${ }^{6}$ The reason for weak private consumption in China was the lack of adequate social safety net comprising the system of pensions, health care and education as well as unemployment insurance that should be financed by the government expenditure to reduce households' propensity to save. ${ }^{7}$ In 2015 the growth rate of real government consumption increased from $4.1 \%$ in 2014 to $9.9 \%$ and the contribution of household consumption to real GDP growth ${ }^{8}$ exceeded the contribution of capital fixed formation. ${ }^{9}$

The essential aim of this chapter is to assess the efficiency of government consumption expenditure in the creation of gross domestic product (GDP) in China. In order to attain this objective the comparative empirical research of China and ASEAN member states, which run broad cooperation in the political and security, economic and socio-cultural area,${ }^{10}$ was conducted. The comparison between countries qualified for the research sample was carried out in the period of ten years from the beginning of global financial crisis. The input-output analysis relied on data from the World Bank data base applied the input-oriented model with constant returns to scale (CCR), which is the basic model in the method of data envelopment analysis (DEA).

4 The demographic transition connected with the disappearance of a demographic dividend i.e. the decrease of working age population, which began after 2011, caused a gradual decline in the savings rate leading to a lower investment rate - the contribution of gross capital formation to real GDP started to weaken. Compare: C. Fang [2016], op. cit., p. 66; World Bank [2017], op. cit., p. 2.

5 W.M. Morrison [2014], op. cit., p. 4.

6 C. Fang [2016], op. cit., p. 130; W.M. Morrison [2014], op. cit., p. 29.

7 W.M. Morrison [2014], op. cit., pp. 27, 32.

8 The changes of economic growth pattern from investment-led growth to final consumptionled growth was one of several objectives, which were established to transform China's economy towards slower but more equitable and sustainable development. Compare: C. Fang [2016], op. cit., p. 131; W.M. Morrison [2014], op. cit., p. 32; World Bank [2017], op. cit., p. 1.

9 World Bank [October 2017], Balancing Act. East Asia and Pacific Economic Update, World Bank Group, Washington, D.C., p. 113.

10 ASEAN Secretariat [April 2017], Overview of ASEAN China Relations, https://web.archive.org/ web/20180825002517; https://asean.org/storage/2016/01/Overview-of-ASEAN-China-RelationsApril-2017.pdf, pp. 1-7 (accessed: 12.10.2019). 


\subsection{Impact of government expenditure on economic growth - literature review}

The link between government expenditure and economic growth has been an issue of sustained interest of researchers conducting studies in the field of public finance both at theoretical and empirical levels for decades. Generally, the empirical research on effects of government expenditure on economic growth, usually measured by the gross domestic product (GDP) growth, were focused on the verification of Keynesian hypothesis stating that the expansion of government expenditure accelerates the economic growth and/or Wagner's law suggesting that the government expenditure increases because of the economic growth.

Barro, ${ }^{11}$ while conducting empirical research on the basis of the cross-section data of 98 economies for the years 1960-1985, considered 14 various regression specifications for the economic growth. The findings of his studies indicated that the association between ratio of real government consumption expenditure to real GDP and growth rate of real GDP per capita was significantly negative. What was more, the relationship between government consumption expenditure and private investment, which was also significantly negative, implied that the decrease in private investment, being the result of distortions introduced by government consumption expenditure, was one route of the decline in economic growth. On the other hand, Barro found that the real government investment expenditure, measured by the ratio to real GDP was positively related to the growth rate of real GDP per capita but this association was statistically insignificant.

Relied on the decade-average data of 36 countries for the 1960s, 108 countries for the 1970s and 119 countries for the 1980s, Easterly and Rebelo ${ }^{12}$ estimated parameters in three versions of the regression function for economic growth, which included the government investment expenditure by sector and level of government. The main result of their empirical research was that, regardless of the analysed version of regression function for economic growth, government investment expenditure on transport and communication sector as well as investment expenditure by general government, both expressed as the share in real GDP were positively correlated with the growth rate of real GDP per capita. The transport and communication investment was not related to private investment, which suggested that it increased the economic growth by rising social return to private investment but not by rising private investment itself. The relationship between general government investment expenditure and private investment was positive.

11 R.J. Barro [1991], Economic Growth in a Cross Section of Countries, "Quarterly Journal of Economics", vol. CVI (425), pp. 407-443.

12 W. Easterly, S. Rebelo [1993], Fiscal policy and economic growthAn empirical investigation, "Journal of Monetary Economics", vol. 32 (3), pp. 417-458. 
Ghura, ${ }^{13}$ taking into account findings of his empirical studies carried out among different in terms of the development level 33 countries in sub-Saharan Africa during the period 1970-1990, could not reject the research hypothesis about the adverse effect of government consumption expenditure on economic growth. The estimated coefficient on real government consumption expenditure in the form of percentage of real GDP in the regression equation for economic growth, which was measured by the growth rate of real GDP per capita, was negative and significant at 0.01 level.

Razzolini and Shughart, ${ }^{14}$ based on the data set comprising 50 states of the USA plus the District of Columbia for the years 1967 through 1992, explored the impact of a relative size of the state government on state income growth. Estimating several versions of regression function for the state income growth with the use of both ordinary last squares (OLS) and panel data techniques, they received the empirical evidence of negative dependence between the ratio of total direct general expenditure to total state personal income and the growth rate in state income per capita, which was significant at 0.05 level. Besides, the income growth was lower in these states where the government size was larger, the high level of government expenditure financed by the increase in taxes to balance state budget appeared to be a worse way of fostering the income growth than the low level of government expenditure financed partly by off-budget borrowing. Additionally, Razzolini and Shughart did not confirm the research hypothesis that the reduction in state income growth caused some changes in the level of government expenditure.

Fölster and Henrekson, ${ }^{15}$ who conducted an econometric panel study on a sample of rich countries covering the period 1970-1995, pointed at a robust negative relationship between the government size and the economic growth. Solving a number of econometric issues in regression specifications to make the estimation of coefficients more reliable, they discovered that an increase in the share of government expenditure in GDP by 10 percentage points led to a decrease in the average growth rate of real GDP per capita on the order of $0.7-0.8$ percentage points.

Loizides and Vamvoukas, ${ }^{16}$ using the time series data from the UK, Ireland and Greece over the period from early 1950s to mid-1990s estimated parameters in three various regression equations for economic growth. The results of their empirical studies revealed that the link between the ratio of government expenditure to gross national product (GNP) and the growth rate of real GNP per capita was

13 D. Ghura [1995], Macro Policies, External Forces, and Economic Growth in Sub-Saharan Africa, "Economic Development and Cultural Change", vol. 43 (4), pp. 759-778.

14 L. Razzolini, W.F. Shughart II [1997], On the (Relative) Unimportance of a Balanced Budget, "Public Choice", vol. 90 (1/4), pp. 215-233.

15 S. Fölster, M. Henrekson [2001], Growth Effects of Government Expenditure and Taxation in Rich Countries, "European Economic Review", vol. 45 (8), pp. 1501-1520.

16 J. Loizides, G. Vamvoukas [2005], Government expenditure andeconomic growth: evidence from trivariate causality testing, "Journal of Applied Economics", vol. 8 (1), pp. 125-152. 
positive and statistically significant in the short run for all investigated countries, and in the long run for Ireland and the UK. Moreover, in Greece not only the rise in government expenditure increased GNP but also the rise in GNP increased the government expenditure, which meant that the causality between considered variables was bi-directional. The causality from GNP to government expenditure in Greece was demonstrated by the bivariate test as well as by both trivariate systems i.e. the system with unemployment rate and the system with inflation rate. The same causality in this research was proved in case of the UK, when the trivariate model with inflation rate was adopted.

Ghosh and Gregoriou ${ }^{17}$ carried out empirical studies on a sample of 15 developing countries during a period of 28 years to examine the influence of various components of government expenditure on economic growth. The findings of their research showed the positive and statistically significant association between the ratio of current expenditure to total government expenditure and the growth rate of real GDP per capita for OLS fixed effects model as well as the general method of moments (GMM) single-equation model and the GMM system. At the same time, in all three applied methodologies, the statistically significant coefficient on capital expenditure also measured by the ratio to total government expenditure, informed that this component of government expenditure was negatively correlated with the growth rate of real GDP per capita.

On the basis of the cross section data of 71 economies at the different level of development spanning from 1996 to 2003 , Cooray ${ }^{18}$ estimated parameters of the neoclassical production function that apart from other variables comprised the size and quality of government to account for their role in the economic growth. The OLS estimation of coefficients in transition model provided the empirical evidence that the relationship between the size and quality of government, expressed respectively by the share of government expenditure to GDP and four governance dummy variables describing the level of governance from very high to very low, and the change of GDP per capita between 2003-1996 was significantly positive. Referring to the effect of government expenditure on economic growth across countries distinguished in terms of governance level, Cooray found out that only in the group of countries with very high governance, the government expenditure was used more effectively leading to a greater economic growth. What was more, the results for the disaggregated model by income distribution, in which government expenditure was divided into investment and consumption expenditure as well as into education, health and military expenditure indicated the significantly positive influence

17 A. Gregoriou, S. Ghosh [2006], On the Composition of Government Spending, Optimal Fiscal Policy, and Endogenous Growth: Theory and Evidence, https://www.brunel.ac.uk/_data/as sets/pdf_file/0010/84475/0619.pdf, pp. 1-28 (accessed: 12.09.2019).

18 A.V. Cooray [2009], Government expenditure, governance and economic growth, "Comparative Economic Studies", vol. 51 (3), pp. 401-418. 
of investment as well as education and health expenditure on economic growth in all analysed countries, no matter the level of their development.

Rehman, Iqbal and Siddiqi, ${ }^{19}$ while conducting empirical studies of Pakistan's economy for the years from 1971 to 2006, explained the causality between the economic growth and the government expenditure along with its various components such as debt services and defence, administrative and development expenditure. Relied on the cointegrated level and Toda-Yamamoto augmented Granger causality test, they rejected the research hypothesis that the real government expenditure amplified the real GDP at both aggregate and disaggregate levels. On the other hand, at bivariate level the rise in real GDP increased the real government expenditure and at multivariate level it increased only the administrative government expenditure.

Jiranyakul, ${ }^{20}$ using quarterly data during 1993-2004 investigated the association between real government expenditure and growth rate of real GDP in Thailand. The findings of standard Granger causality test at the $1 \%$ level of significance allowed him to reject the research hypothesis that government expenditure did not cause economic growth and to confirm the one that postulated the lack of existence of the causality from economic growth to government expenditure. After the OLS estimation of regression equation for economic growth, he also discovered that real government expenditure and its one-period lag variable had highly significant effect on the growth rate of real GDP.

In the context of data for nine countries from different Asian regions and at the different development level comprising the period from 1970 to 2013, Lahirushan and Gunasekara ${ }^{21}$ described the link between government expenditure and GDP, both given in absolute constant values in USD. Having applied the econometrical techniques of cointegration, panel fixed effects model and Granger causality test, they found out that the impact of government expenditure on GDP was significantly positive as well as the causality ran from government expenditure to GDP and vice versa.

Hasnul, ${ }^{22}$ based on time series data during the period 1970-2014, employed OLS technique to identify whether in Malaysian economy there was a fixed effect

19 J. Rehman, A. Iqbal, M.W. Siddiqi [2010], Cointegration-Causality Analysis between Public Expenditures and Economic Growth in Pakistan, "European Journal of Social Sciences", vol. 13 (4), pp. 556-565.

$20 \mathrm{~K}$. Jiranyakul [2013], The relation between government expenditures and economic growth in Thailand, “MPRA Paper”, vol. 46070, pp. 1-7, https://mpra.ub.uni-muenchen.de/46070/ (accessed: 12.09.2019).

21 K.P.K.S. Lahirushan, W.G.V. Gunasekara [2015], The Impact of Government Expenditure on Economic Growth: A Study of Asian Countries, "International Journal of Humanities and Social Sciences", vol. 9 (9), pp. 3152-3160.

22 A.G. Hasnul [2016], The effects of government expenditure on economic growth: the case of Malaysia, "MPRA Paper", vol. 71254, pp. 1-16, https://mpra.ub.uni-muenchen.de/71254/ (accessed: 12.09.2019). 
of government expenditure split into various categories and types on economic growth, in which explored variables were respectively measured by the percentage of GDP and the growth rate of real GDP. The findings of his empirical studies indicated that the relationship between total government expenditure and economic growth was negative and significant at $5 \%$ level. Considering operating and development expenditure as well as education, health, defence and housing expenditure, he discovered that only development and housing expenditure significantly affected the growth rate of real GDP.

Gupta, ${ }^{23}$ who carried out the analysis of the data for the period of 2002/20032015/2016 estimating parameters of the regression model, determined which components of government expenditure supported the economic growth in Nepal. The results of his empirical research showed that at the $5 \%$ level of significance, government expenditure on agriculture, non-agriculture, industry and service sector were positively related to the economic growth while capital and current expenditure was related negatively.

The empirical studies on the impact of government expenditure on economic growth generated a lot of controversies, for the simple reason that their results differed significantly in accordance with the analysed countries and periods as well as applied research methods and techniques.

\subsection{Research Methodology}

The gross domestic product (GDP) is a standard monetary measure of economic activities of a given country in a specified time period as well as the single most frequently used indicator although it is widely criticised not only by economists. ${ }^{24}$ GDP is determined in the system of national accounts in three equivalent approaches: ${ }^{25}$

- an output approach - the sum of gross value added (output less intermediate consumption) of households, non-profit institutions, government and enterprises increased by taxes net of subsidies of products;

23 R. Gupta [2018], The impact of government expenditure on economic growth in Nepal, pp. 1-6, https://papers.ssrn.com/sol3/papers.cfm?abstract_id=3099218 (accessed: 12.09.2019).

24 GDP as a measure of costs rather than benefits of economic activities does not capture all social costs as well as GDP per capita identified with the social welfare indicator presents only the average income in the economy not the income distribution. See: J.C.J.M. van den Bergh [2009], The GDP paradox, "Journal of Economic Psychology", vol. 30, pp. 117-135.

25 OECD [2014], National Accounts at a Glance 2014, OECD Publishing, Paris, p. 36; F. Lequiller, D. Blades [2014], Understanding National Accounts: Second Edition, OECD Publishing, Paris, p. 20; System of National Accounts 2008 [2009], EC, IMF, OECD, UN, WB, New York, pp. 104-105. 
- an income approach - the sum of employee compensation, gross operating surplus of enterprises and government, gross mixed incomes of unincorporated enterprises and net taxes on production and imports;

- a final demand approach - the sum of final consumption expenditure of households, non-profit institutions and government, gross capital formation and exports less imports.

Bearing in mind the essential aim of this chapter, the basis of the empirical research on the efficiency of final consumption expenditure by general government in the creation of GDP in China is the GDP measure from the final demand side. GDP as the expenditure on final goods and services minus imports is calculated by the following formula: ${ }^{26}$

$$
G D P=C+G C F+N E
$$

where:

$G D P$ - gross domestic product,

C - final consumption expenditure,

$G C F$ - gross capital formation,

$N E$ - net export.

The final consumption expenditure (total consumption) consists of household final consumption expenditure with expenditure of non-profit institutions serving households (NPISHs) ${ }^{27}$ and general government final consumption expenditure, ${ }^{28}$ which can be divided into the individual ${ }^{29}$ and collective ${ }^{30}$ consumption expenditure. The final consumption expenditure of households (private consumption) includes purchases of goods and services used by households to meet their everyday needs, ${ }^{31}$ partial payments for goods and services provided by general government and payments to general government for different types of licences/ permits as well as some imputed expenditures. ${ }^{32}$ The final

26 World Bank [1960-2018], Data - GDP (current USD), https://data.worldbank.org/indicator/ ny.gdp.mktp.cd (accessed: 12.10.2019).

27 The World Bank treats the household final consumption expenditure and final consumption expenditure of NPISHs together, even when they are reported separately in the national statistics of a given country.

28 Compare: F. Lequiller, D. Blades, op. cit., p. 140.

29 The general government expenditure for individual consumption reflects the expenditure by general government incurred on behalf of an individual household, for example expenditure on health care system or education system.

30 The general government expenditure for collective consumption relates the expenditure by general government which benefit the whole society or its large part, for example expenditure on national defence system or justice system.

31 The expenditure of households on final goods and services which meet their everyday needs includes purchases of durable products but excludes purchases of dwellings.

32 The imputed expenditure covers for example rent for owner-occupied dwellings as well as value of goods and services received by employees as a part of their wages. 
consumption expenditure by general government (public consumption) is the sum of its following costs: ${ }^{33}$ compensation of employees of the government, purchases of materials and other intermediate consumption items by the government, consumption of government fixed capital, purchases of goods and services by the government for the benefit of households and other taxes on production paid without the costs of both partial payments of households and enterprises for goods and services provided by the government and own account production of gross fixed capital formation. The gross capital formation (gross domestic investment) consists of outlays on fixed assets of the economy (private and public investment - gross fixed domestic formation), ${ }^{34}$ net changes of inventories and net acquisitions of valuables. The net exports is a difference between exports and imports of goods and services.

The empirical studies, comparing the efficiency of general government final consumption expenditure in the creation of GDP in China to the efficiency of this expenditure in nine ASEAN member states ${ }^{35}$ in the years between 2008-2017 were conducted applying the method of data envelopment analysis (DEA). The DEA method $^{36}$ measures the relative technical efficiency ${ }^{37}$ of decision making units (DMUs) based on the estimation of the relation between multiple inputs and multiple outputs. The efficiency of a given decision making unit (DMU) measured by the DEA method is described as a quotient of the weighted sum of outputs to the weighted sum of inputs, which looks as follows: ${ }^{38}$

$$
e_{i}(u, v)=\frac{\sum_{r=1}^{p} u_{r i} y_{r i}}{\sum_{t=1}^{s} v_{t i} y_{t i}}
$$

33 See: OECD, op. cit., p. 42; F. Lequiller, D. Blades, op. cit., pp. 139-140.

34 The gross fixed domestic formation of households and general government includes for example the purchase of dwellings and expenditure on transport infrastructure, military defence system, office buildings, hospitals and schools, respectively.

35 Myanmar as the member state of ASEAN was not taken into account in comparative empirical studies because the data about general government final consumption expenditure which was available in the World Bank database covered only for the period from 2010 to 2016.

36 The DEA method derives from the concept of microeconomic productivity function. The productivity measure is described as the ratio of a single output to a single input. See: G. Debreu [1951], The Coefficient of Recourse Utilization, "Econometrica", vol. 19 (3), pp. 273-292; M.J. Farell [1957], The Measurement of Productive Efficiency, "Journal of the Royal Statistical Society", series A, vol. 120 (3), pp. 253-290.

37 The relative technical efficiency is understood as the relation between productivity of a given $D M U$ to the productivity of efficient DMU. See: A. Domagała [2007], Metoda Data Envelopment Analysis jako narzędzie badania względnej efektywności technicznej, "Operations Research and Decisions", vol. 3-4, p. 23.

38 A. Kucharski [2014], Metoda DEA w ocenie efektywności gospodarczej, Wydawnictwo Uniwersytetu Łódzkiego, Łódź, p. 11. 
where:

$e_{i}(u, v)$ - efficiency measure for $i$-th $D M U$,

$i \quad$ - index denoting a given $D M U, i=1, \ldots, n$,

$p \quad-$ number of outputs, $(r=1, \ldots, p)$,

$s \quad-$ number of inputs, $(t=1, \ldots, s)$,

$u_{r i} \quad$ - weight of $r$-th output for $i$-th $D M U$,

$v_{t i} \quad-$ weight of $t$-th input for $i$-th $D M U$,

$y_{r i} \quad-r$-th output of $i$-th DMU,

$x_{t i} \quad-t$-th input of $i$-th DMU.

The estimation of a efficiency measure with the DEA method can be made in the framework of four different models in terms of their assumptions:

- a model with constant returns to scale (CRS); ${ }^{39}$

- a model with variable returns to scale (VRS); ${ }^{40}$

- a model with non-increasing returns to scale (NIRS); ${ }^{41}$

- a model with non-decreasing returns to scale (NDRS). ${ }^{42}$

Moreover, the DEA method allows to estimate the efficiency measure in three various forms: ${ }^{43}$

- input-oriented efficiency - minimizing inputs while unchanged outputs;

- output-oriented efficiency - maximizing outputs while unchanged inputs;

- efficiency without the orientation.

The unquestionable advantage of the DEA method ${ }^{44}$ is that many heterogeneous inputs and outputs ${ }^{45}$ can be taken into consideration without the need to

39 This model in the economic literature is marked from the names of its authors (A. Charnes, W.W. Cooper and A. Rhodes) as CCR. See: A. Charnes, W.W. Cooper, B. Golany, L.M. Seiford, J. Stutz [1985], Fundations of DEA for Pareto-Koopmans Efficient Empirical Production Function, "Journal of Economics", vol. 30 (1-2), pp. 91-107.

40 This model in the economic literature is marked from the names of its authors (R.D. Banker, A. Charnes and W.W. Cooper) as BCC. See: R.D. Banker, A. Charnes, W.W. Cooper [1984], Some Models for Estimating Technical and Scale Inefficiencies in Data Envelopment Analysis, "Management Science", vol. 30 (9), pp. 1078-1092.

41 See: R. Fäare, S. Grosskopf, C.A. K. Lovell [1985], The Measurement of Efficiency of Production, Kluwer Academic Publishers, Boston.

42 See: S. Ylvinger [2000], Essays on Production Performance Assessment, "Umeå Economic Studies", vol. 531.

43 The $D E A$ efficiency is also Pareto efficiency which means that a given $D M U$ is fully efficient if and only if it is not possible to make any inputs or outputs better off (decrease of inputs or increase of outputs) without making the others worst off (increase of inputs or decrease of outputs). See: A. Charnes, W.W. Cooper, E. Rhodes [1978], Measuring the efficiency of decision making units, "European Journal of Operational Research", vol. 2 (6), p. 433.

44 Compare: A. Sajnóg [2015], Comparative Analysis of Economic Efficiency of Polish and German Listed Companies, "Oeconomia Copernicana”, vol. 6 (2), p. 71.

45 Inputs and outputs can be expressed in diverse units, even not monetary ones but their values cannot be negative as well as at least one input and at least one output for each DMU must be different from zero. 
determine their weights ${ }^{46}$ and functional relationship, ${ }^{47}$ which causes that it is widely implemented in the efficiency assessment of DMUs. ${ }^{48}$

The efficiency measure in DEA method takes values between 0 and 1, but the value equal to 1 reflects the full efficiency of a given DMU. In the case of the inputoriented CCR model, treated as a basic model in the DEA method, the efficiency measure amounting to 1 indicates that optimal inputs to achieve given outputs are the same as real inputs. ${ }^{49}$ On the other hand, measure of DEA efficiency lower than 1 signals that optimal inputs to obtain given outputs are not highest than real inputs. ${ }^{50}$

The comparative analysis of the efficiency of general government final consumption expenditure in the creation of GDP in China and nine ASEAN member states using the DEA method was conducted on the basis of the input-oriented model with constant returns to scale (CCR), where the final consumption expenditure by general government was assumed for the input and the size of GDP for the output $^{51}$ - both variables over ten-year research period for each examined country, which was treated in the comparative analysis as DMU were expressed in current

46 Weights of inputs and weights of outputs, which define their importance and maximize the efficiency of each $D M U$ are generated during the estimation of $D E A$ efficiency measures.

47 The $D E A$ method as a non-parametric technique does not require to define the production function to present the functional dependence between inputs and outputs.

48 Y.J. Feng, H. Lu, K. Bi [2004], An AHP/DEA method for measurement of the efficiency of R\&D management activities in universities, "International Transactions in Operational Research", vol. 11 (2), pp. 181-191; A. Feruś [2006], Zastosowanie metody DEA do określania poziomu ryzyka kredytowego przedsiębiorstw, "Bank \& Credit", vol. 7, pp. 44-59; M. Helta [2009], Zastosowanie metody DEA do opracowania rankingu efektywności spółek Agencji Nieruchomości Rolnych w 2006 roku, "Annals of Agricultural Sciences", series G, vol. 96 (3), pp. 107-111; R. Jacobs [2001], Alternative methods to examine hospital efficiency: data envelopment analysis and stochastic frontier analysis, "Health Care Management Science", vol. 4 (2), pp. 103-115; A. Sajnóg, T. Sosnowski [2015], Efektywność realizacji procesów dezinwestycji funduszy private equity na GPW w Warszawie, "Studies and Works College of Management and Finance", vol. 143, pp. 55-76; T. Sueyoshi, M. Goto [2012], Data envelopment analysis for environmental assessment: Comparison between public and private ownership in petroleum industry, "European Journal of Operational Research", vol. 216 (3), pp. 668-678; W.-H. Tsai, H.-L. Lee, C.-H. Yang, C.-C. Huang [2016], Input-Output Analysis for Sustainability by Using DEA Method: A Comparison Study between European and Asian Countries, "Sustainability", vol. 8 (12), pp. 1-17, https://www.mdpi.com/2071-1050/8/12/1230 (accessed: 04.09.2019).

49 The efficient $D M U$ sets the border of efficiency, which being also the border of production possibilities for the whole examined group of entities may be used by inefficient DMUs in searching for the optimal level of inputs. See: A. Domagata, op. cit., p. 25.

50 The degree of inefficiency in a given $D M U$ is described by the difference between 1 and calculated measure of $D E A$ efficiency $e_{i}(u, v)$. See: A. Kucharski, op. cit., p. 10.

51 The terms "inputs" and "outputs" have a certain conventional character. As far as connection of the term "output" with returns is justified in this study, the term "inputs", which usually refers to costs, is used only to perform the role of customary terminology used in the terminology of $D E A$ method. 
USD. ${ }^{52}$ In order to investigate the role and significance of general government expenditure on final consumption in the creation of GDP in China and nine ASEAN member states, the empirical studies included additionally the evaluation of a percentage share of general government final consumption expenditure in GDP ${ }^{53}$ and the analysis of a correlation dependence between examined variables.

Identifying the correlation dependence ${ }^{54}$ between GDP and general government final consumption expenditure and defining its direction and strength the Spearman's rank correlation coefficient (Spearman's rho) was applied. ${ }^{55}$ The Spearman's $r h o,{ }^{56}$ which requires assigning the ranks ${ }^{57}$ to the values of investigated variables $x$ and $y^{58}$ and to determine the variable $d_{i}$, which is the difference between the ranks of $i$-th values of each variable, is calculated in the following way:

where:

$$
r_{s}=1-\frac{6 \sum_{i=1}^{n} d_{i}^{2}}{n\left(n^{2}-1\right)}
$$

$r_{s} \quad$ - Spearman's rank correlation coefficient,

$n$ - number of observations,

$d_{i}=R x_{i}-R y_{i}$,

$R x_{i}-$ rank of $i$-th observation of variable $x$,

$R y_{i}-\operatorname{rank}$ of $i$-th observation of variable $y$.

52 The variables expressed in constant or current international $\$$ could not be used because the data about general government final consumption expenditure in this currency are not available in the World Bank database for any country. The variables expressed in constant US\$ could not also be used due to the lack of data about general government final consumption expenditure in constant currencies for China.

53 The evaluation of percentage share of general government final consumption expenditure in $G D P$ was based on the descriptive statistic.

54 The correlation association is a special case of a stochastic relationship, which consists in the fact that with the change of one variable, the probability distribution of the other variable changes. See: C. Domański [2001], Analiza korelacji i regresji, in: C. Domański (ed.), Metody statystyczne. Teoria i zadania, Wydawnictwo Uniwersytetu Łódzkiego, Łódź, p. 170.

55 In the study of correlation dependence, the Pearson's linear correlation coefficient is most commonly used, but if a number of variants of measurable variables is small and their distributions are not normal to examine the direction and strength of the association between variables, the Spearman's rank correlation coefficient is a more appropriate measure. See: M. Sobczyk [2010], Statystyka opisowa, C. H. Beck, Warszawa, p. 117.

56 The Spearman's rho is a nonparametric measure defined as the Pearson's linear correlation coefficient between the ranked variables. See: J.L. Myers, A.D. Well [2003], Research Design and Statistical Analysis (2nd ed.), Lawrence Erlbaum Associates Publishers, New JerseyLondon, p. 508.

57 The advantage of ranks correlation is that it is not sensitive to outliers (unusual).

58 The assignment of the rank $R x_{i}$ to $i$-th observation of variable $x$ and the rank $R y_{i}$ to $i$-th observation of variable $y$ means giving to the values of variables $x$ and $y$ consecutive numbers from 1 to $n$ in ascending or descending order, but the same order for both variables. 
Table 5.1. Classification for values of the Spearman's rank correlation coefficient in terms of the strength of the correlation dependence

\begin{tabular}{|c|c|}
\hline Value of the Spearman's rho & $\begin{array}{c}\text { Strength of the correlation } \\
\text { dependence }\end{array}$ \\
\hline$(0- \pm 0.2>$ & very weak \\
\hline$( \pm 0.2- \pm 0.4>$ & weak \\
\hline$( \pm 0.4- \pm 0.6>$ & moderate \\
\hline$( \pm 0.6- \pm 0.8>$ & strong \\
\hline$( \pm 0.8- \pm 1.0>$ & very strong \\
\hline
\end{tabular}

Source: own elaboration based on: M. Sobczak [2010], op. cit., pp. 111, 118

The Spearman's rho takes values in the range $\langle-1 ; 1\rangle$. The sign of the correlation coefficient shows the direction of correlation dependence, and the absolute value reflects its strength. A correlation coefficient of 0 means that the examined variables are not correlated and thus indicates a lack of correlation dependence between them. If the correlation coefficient is equal to 1 , then there is a full compliance of ranks of the examined variables (perfect positive association of ranks), and if it is equal to -1 , then there is a full non-compliance of ranks (perfect negative association of ranks). In order to characterise the strength of the correlation dependence between the investigated variables, the following classification for values of the Spearman's rho was defined (table 5.1). Assessing the statistical significance of the Spearman's rho, there was used the critical level of significance $p$-value, ${ }^{59}$ which should be interpreted as the lowest level of statistical significance $\alpha$ allowing to reject the null hypothesis, stating that Spearman's rho equals to zero in favour of the alternative hypothesis, stating that it is significantly different from zero. ${ }^{60}$

59 Using the critical level of significance $p$-value in the course of assessing statistical significance as opposed to $t$-statistics, which has a Student's $t$-distribution with $n-2$ degrees of freedom, allows to know the results of a statistical test for a given hypothesis at all levels of statistical significance $\alpha$.

60 The critical level of significance - $p$-value is the level of statistical significance $\alpha$ at which the critical value of Student's $t$-test $-t_{\alpha}$ is equal to its value calculated from the sample - $-t=r_{s} \sqrt{\frac{n-2}{1-r_{s}^{2}}}$. Compare: J. Jóźwiak, J. Podgórski [2009], Statystyka od podstaw, PWE, Warszawa, pp. 242-245. 


\subsection{Efficiency of general government final consumption expenditure in the creation of GDP - results of empirical research}

The empirical research on the differentiation of China's and nine ASEAN member states' economic efficiency in terms of gross domestic product (GDP) while minimizing general government expenditure on final consumption, in addition to assessing the efficiency measures estimated in the basic model of data envelopment analysis (DEA), included the evaluation of a percentage share of general government final consumption expenditure in GDP and the analysis of a correlation dependence between these variables.

The mean share of general government expenditure on final consumption in GDP for the examined group of countries in the years 2008-2017 fluctuated, increasing in 2009, 2012 and 2013 as well as in 2015. The mean share of final consumption expenditure by general government in GDP ranged from $10.26 \%$ in 2008 to $12.71 \%$ in 2015 , with the above-average mean share observed in 2009 and in the period after the year 2013. The standard deviation of a share of general government final consumption expenditure in GDP after the year 2011 systematically increased, thus indicating the rising differentiation of investigated countries in terms of the importance of general government final consumption expenditure for creating the demand on final goods and services. The share of general government expenditure on final consumption in GDP after the year 2008 in every second analysed country was higher than $11.43 \%$.

The lowest share of general government final consumption expenditure in GDP in the period to 2011 took place in Vietnam, and since 2012 in Cambodia. The mid-term share of general government expenditure on final consumption in GDP in both these countries was lower than the average share for the examined group of countries. Brunei Darussalam where the highest share of final consumption expenditure by general government in GDP appeared in each year of the adopted ten-year research period, was characterized by the highest average annual share among investigated countries. The above-average mid-term share of general government final consumption expenditure in GDP beyond Brunei Darussalam was noted in China, Malaysia, Thailand and Laos (table 5.2.).

The share of general government expenditure on final consumption in GDP in China during the considered research period showed a slow upward trend, decreasing only in 2010 and 2014 - this share was within the range from 13.20\% in 2008 to $14.59 \%$ in 2017. In ASEAN countries without Myanmar (ASEAN - 9), the average share of final consumption expenditure by general government in GDP in 2017 was higher than in 2008, however, the largest average share of $12.56 \%$ was recorded in the year 2015. It is worth highlighting that compared to the share of general government 


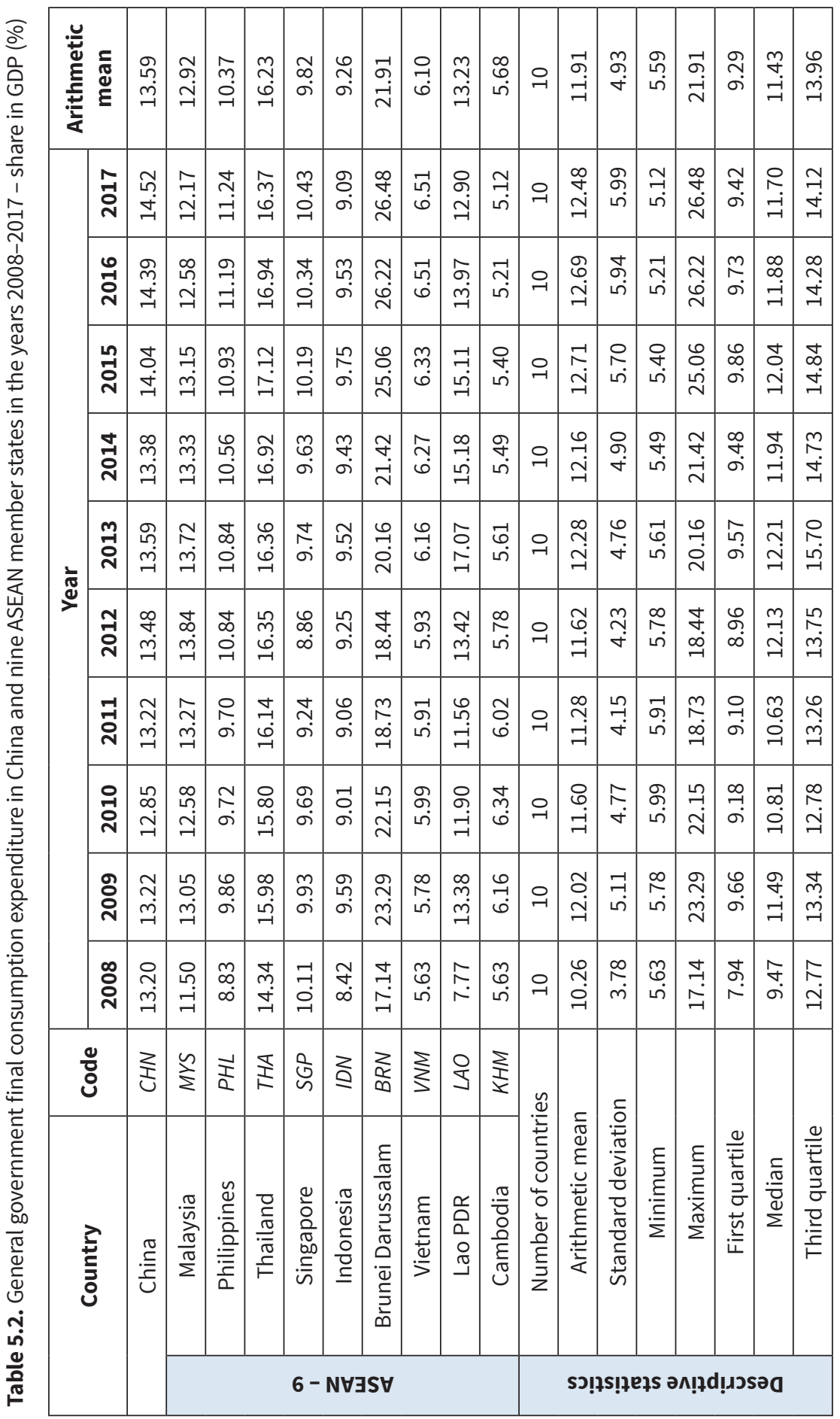


final consumption expenditure in GDP in China, the average share in nine ASEAN countries not only revealed greater variability, but was also lower throughout the entire ten-year research period (figure 5.1.).

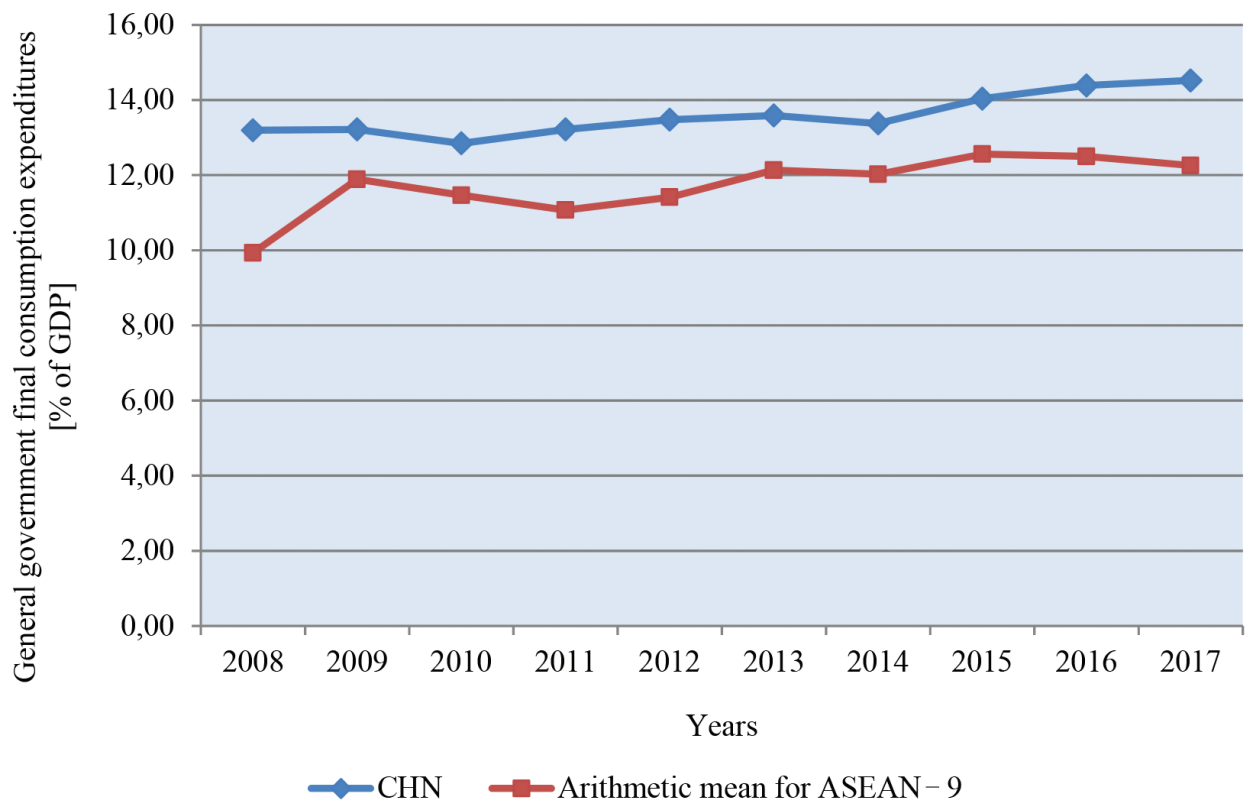

Figure 5.1. General government final consumption expenditure in China and nine ASEAN member states in the years $2008-2017$ (\% of GDP)

Source: own elaboration based on table 5.2.

In each investigated country, the Spearman's rank correlation coefficient (Spearman's $r h o$ ) was positive and statistically significant at the significance level $\alpha=0.05$. This means, therefore, that in the years 2008-2017 in particular countries, the increase in general government expenditure on final consumption was accompanied by the increase in GDP. The correlation dependence between general government final consumption expenditure and GDP in Brunei Darussalam was strong and in other countries it was very strong, with the Spearman's rho for China, Vietnam and Cambodia amounted to 1 (table 5.3.).

The mean measure of DEA efficiency for the examined group of countries in the years 2008-2017, gradually decreasing during 2012-2016, ranged from 0.6218 in 2008 to 0.4972 in 2016. The standard deviation of a DEA efficiency measure fluctuated, declining in 2010, 2014 as well as in 2016 and 2017. The highest differentiation of investigated countries in terms of the estimated DEA efficiency measures took place in the year 2014, when the standard deviation amounted to 0.2447 (table 5.4.). 
Table 5.3. Relationship between gross domestic product and general government final consumption expenditure in China and nine ASEAN member states in the years 2008-2017 - Spearman's rank correlation coefficient [-]

\begin{tabular}{|c|c|c|c|c|c|c|}
\hline \multicolumn{2}{|r|}{ Country } & Code & Valid $N$ & Spearman's rho $\left(r_{s}\right)^{\star}$ & t-stat & p-value \\
\hline & China & $\mathrm{CHN}$ & 10 & 1.000000 & $\mathrm{x}$ & $\mathrm{x}$ \\
\hline \multirow{9}{*}{$\begin{array}{l}a \\
1 \\
z \\
z \\
\text { 岕 } \\
\frac{u}{<}\end{array}$} & Malaysia & MYS & 10 & 0.903030 & 5.945747 & 0.000344 \\
\hline & Philippines & PHL & 10 & 0.987879 & 18.000339 & 0.000000 \\
\hline & Thailand & THA & 10 & 0.951515 & 8.749268 & 0.000023 \\
\hline & Singapore & SGP & 10 & 0.975758 & 12.610493 & 0.000001 \\
\hline & Indonesia & IDN & 10 & 0.951515 & 8.749268 & 0.000023 \\
\hline & Brunei Darussalam & BRN & 10 & 0.672727 & 2.571678 & 0.033041 \\
\hline & Vietnam & VNM & 10 & 1.000000 & $x$ & $x$ \\
\hline & Lao PDR & LAO & 10 & 0.951515 & 8.749268 & 0.000023 \\
\hline & Cambodia & KHM & 10 & 1.000000 & $\mathrm{x}$ & $\mathrm{x}$ \\
\hline
\end{tabular}

* With the Spearman's rho equal to 1 , the value of Student's t-test from the sample - $t$ cannot be calculated (the expression in the denominator of the formula for the value of Student's t-test

from the sample - $t$ is zero), and therefore the level of statistical significance $\alpha$, at which the critical value of Student's t-test - $t_{\alpha}$ is equal to its value calculated from the sample $-t$, i.e. the critical level of significance - $p$-value cannot be determined

Source: own elaboration based on data of the World Bank with the Statistica 12 software

The most efficient year from the point of view of the achieved size of GDP while minimizing general government final consumption expenditure was the year 2008, when the estimated measure of DEA efficiency in every second analysed country was at least equal to 0.5966 . The year 2016, when the estimated DEA efficiency measure in three out of four examined countries was at most equal to 0.5361, was the least efficient year. Refering to the mean measure of DEA efficiency for the whole ten-year research period, the period up to the year 2012 was above-average in terms of efficiency (compare: table 5.4., figure 5.2.).

The highest DEA efficiency measure of 1.00 occurred in Vietnam in the period to 2011 and in Cambodia since 2012. The above-average mid-term measure of DEA efficiency, except countries, where the efficiency in terms of the reached size of GDP while minimizing general government expenditure on final consumption was periodically full, was observed in Singapore and Indonesia. Brunei Darussalam, where the lowest DEA efficiency measure appeared in each year of the adopted ten-year research period, marked the lowest average annual efficiency measure among investigated countries (compare: table 5.4., figure 5.3.). 


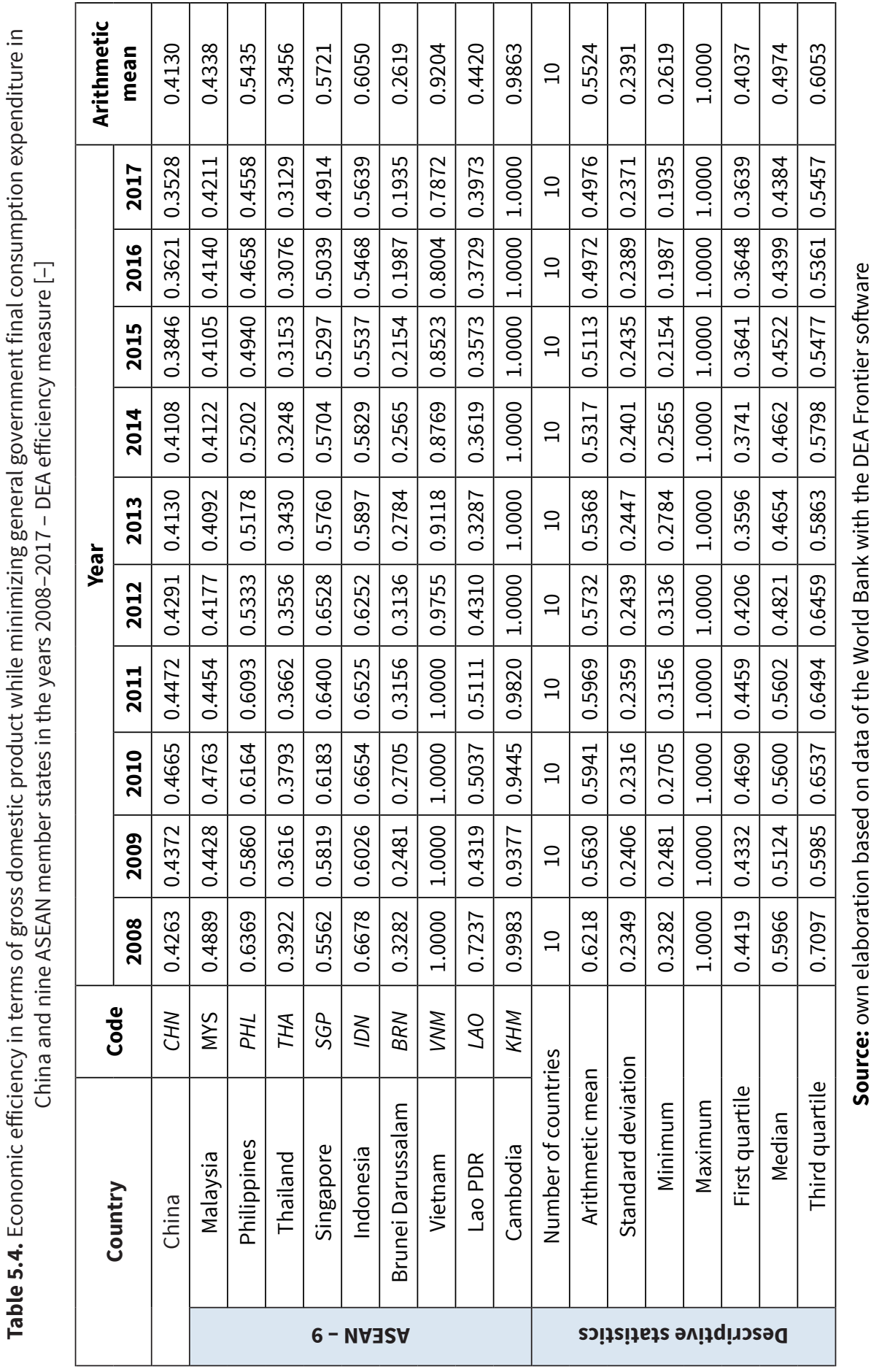




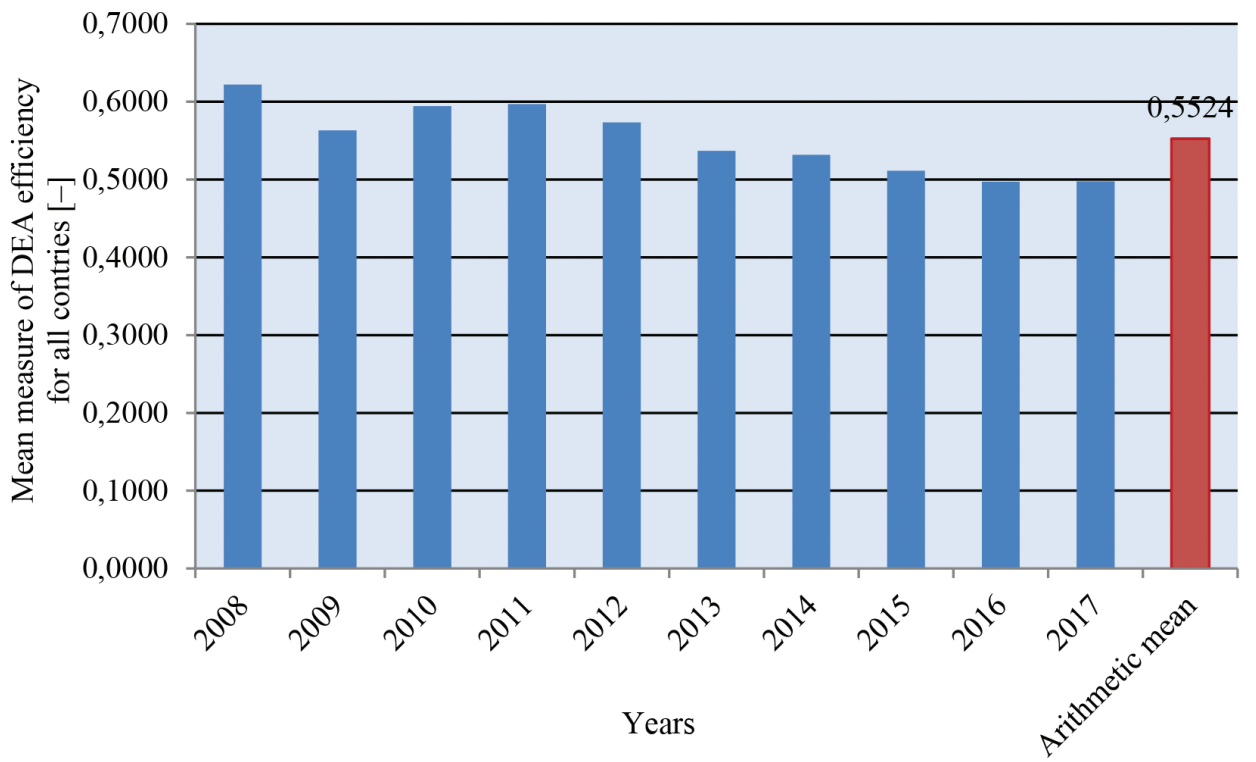

Figure 5.2. Mean measure of DEA efficiency for all countries in the years 2008-2017 [-]

Source: own elaboration based on table 5.4.

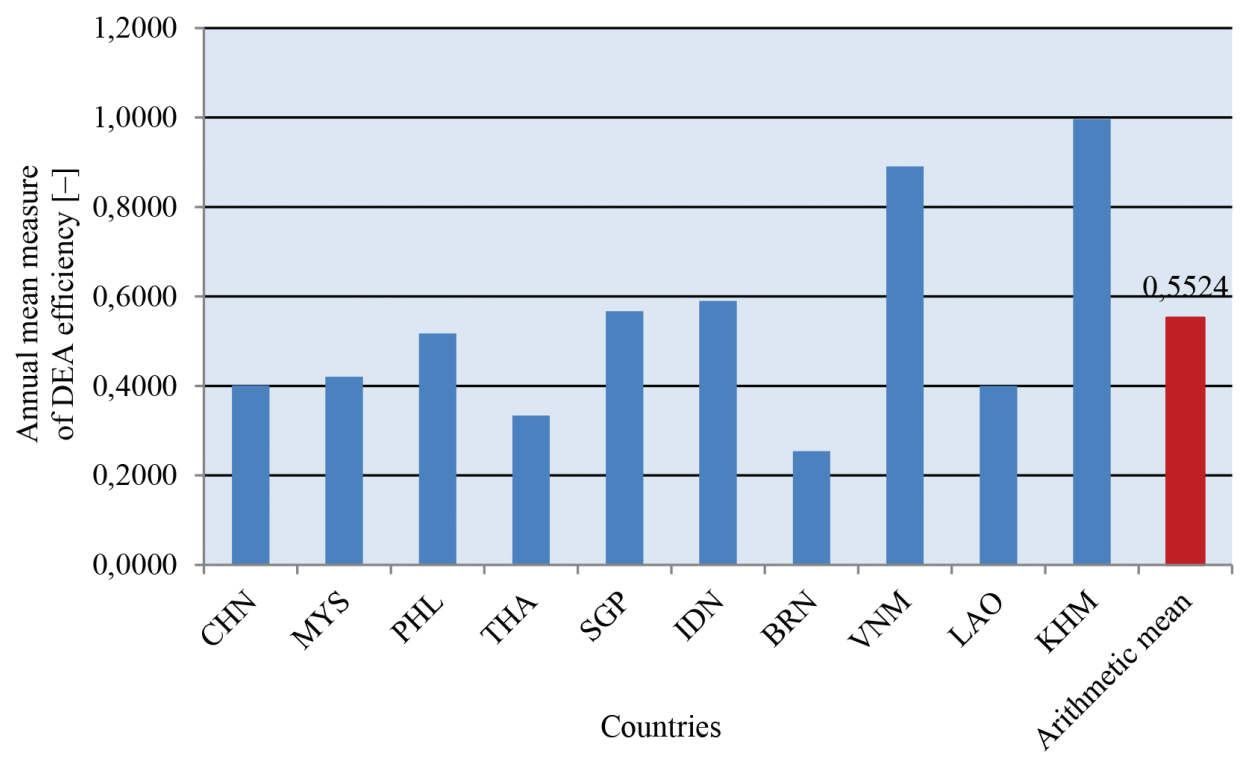

Figure 5.3. Annual mean measure of DEA efficiency in China and nine ASEAN member states [-] Source: own elaboration based on table 5.4. 


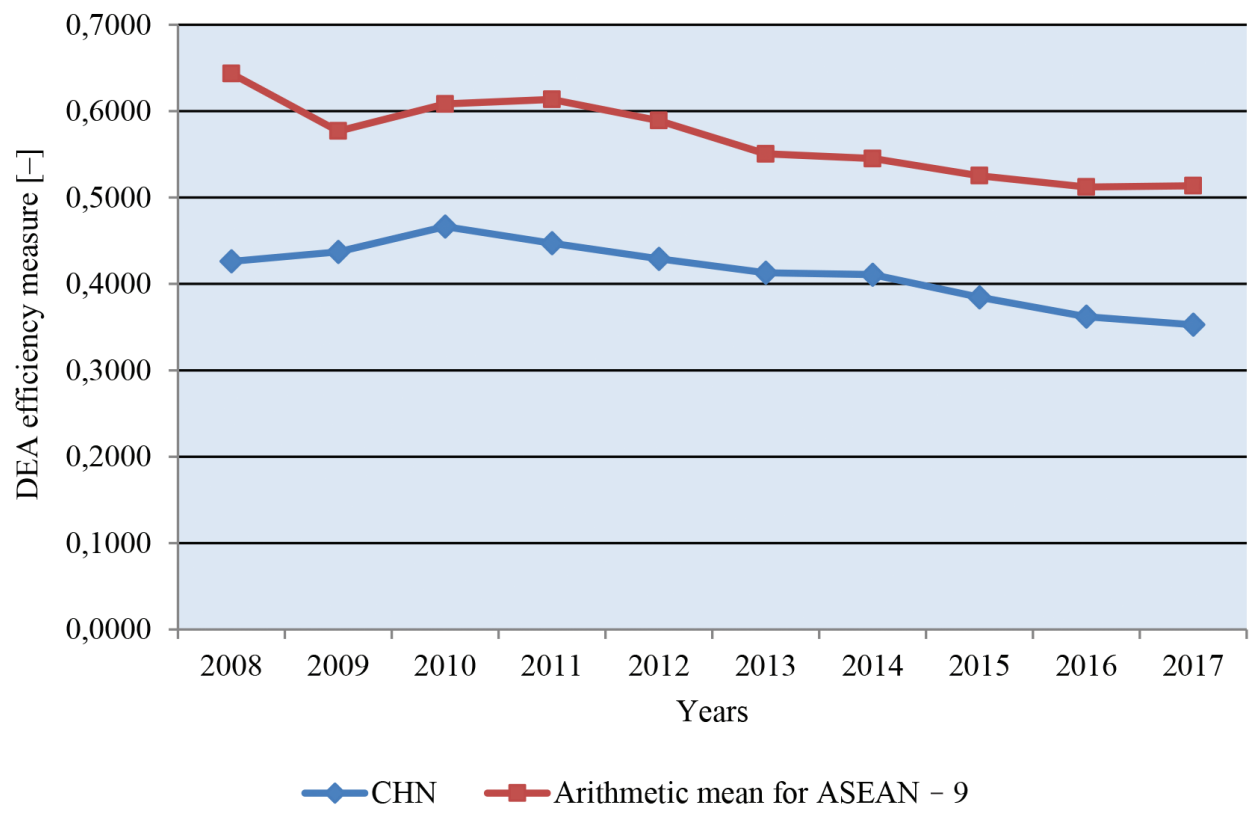

Figure 5.4. DEA efficiency measure in China and nine ASEAN member states in the years 2008-2017 [-]

Source: own elaboration based on table 5.4.

The estimated measure of DEA efficiency in China over the considered research period showed a slow downward trend, increasing only during 2009-2010 - this efficiency measure fell into the range from 0.3528 in 2017 to 0.4665 in 2010. In ASEAN countries without Myanmar (ASEAN - 9), the mean measure of DEA efficiency in 2017 was lower than in 2008, although the lowest average efficiency measure of 0.5122 was noticed in 2016. Similarly to the share of final consumption expenditure by general government in GDP, the average DEA efficiency measure in nine ASEAN countries was more volatile than the efficiency measure in China, but throughout the entire ten-year research period it was higher than China's efficiency measure (figure 5.4.).

\section{Conclusions}

On the basis of obtained empirical results the following broad conclusions emerged:

- the highest average share of general government final consumption expenditure in GDP for ASEAN member states without Myanmar (ASEAN - 9), 
which appeared in $2015(12.56 \%)$ was below the lowest share for China that occurred in 2010 (12.85\%);

- the average annual share of final consumption expenditure by general government in GDP for Brunei Darussalam was the largest among the investigated countries, but the positive relationship between the analysed variables, which was significant at 0.05 level, albeit still strong, was weaker;

- in Vietnam and Cambodia, which were characterised by a very small average annual share of general government expenditure on final consumption in GDP, the positive relationship between the examined variables, just like for China, was perfect;

- countries with a relatively low share of general government final consumption expenditure in GDP had a relatively high average annual measure of DEA efficiency;

- the mid-term share of general government expenditure on final consumption in GDP for China (13.59\%) was higher than the average mid-term share (11.91\%), and the mid-term DEA efficiency measure (0.4130) was lower than the average mid-term measure (0.5524);

- the highest measure of DEA efficiency in China was observed in 2010 (0.4665) with the lowest share of final consumption expenditure by general government in GDP (12.85\%) - the lowest measure of DEA efficiency was noted in 2017 (0.3528) with the highest share of final consumption expenditure by general government in GDP (14.52\%);

- the highest DEA efficiency measure in China that appeared in $2010(0.4665)$ was under the lowest average efficiency measure for ASEAN member states without Myanmar (ASEAN - 9) that occurred in 2015 (0.5122).

These empirical studies allowed to assess the efficiency of general government final consumption expenditure in the creation of GDP in China against the background of nine ASEAN countries in the adopted ten-year research period but they did not take into account the significance of individual components of general government expenditure on final consumption. Therefore, the future empirical research could be continued towards assessing the efficiency of particular kinds of final consumption expenditure by general government in the creation of GDP as well as it could be conducted in the comparison to other Asian countries than ASEAN member states or to the United States and members of European Union. Besides, the empirical studies on the efficiency of final consumption general government expenditure in the creation of GDP in China should be continued because this issue seems to be important in the scope of a significance of government expenditure in the transformation of economic growth pattern from investmentled growth to consumption-led growth - in the transformation, which supported by changes in monetary policy (chapter 6) can determine the development of strategic sectors (chapter 4$)$. 



\section{Chapter 6}

\section{Challenges ahead of the banking sectors in Asia}

Klaudia Zielińska-Lont*

(iD) https://orcid.org/0000-0003-3738-0468

As the Asian-Pacific economies are maturing, the profitability of its financial institutions is slowly coming down to the global average. This comes not only as a consequence of slower economic growth or intensified competition, but also due to new policies and initiatives, such as sustainable finance. As a result, financial institutions in the region will need to seek to consolidate their businesses in order to increase their efficiency and protect their market share. The aim of this chapter is to evaluate the consequence of changing micro- and macroeconomic environment for the banking sectors in Asia as of 2013, with an emphasis on Malaysia, Indonesia and Thailand.

This chapter is divided into five sections, starting with a broad overview of the banking sector in Asia. That section is followed by a more detailed description of the developments in some of the major banking sectors in the region. The two consecutive sections provide respectively a description of the situation in the chosen banking sectors in 2019 and an outlook for the future in view of the changing environment. Last section includes concluding remarks on the current condition of the credit institutions in Asia and how they can adapt to the new market reality.

* University of Lodz, Department of International Business and Trade. 


\subsection{Asia's banking sector - overview}

Banks in many Asian country experienced a golden age of prosperity until the late 90 's, since the economic situation was extremely favourable and the need for financing was overwhelming. The revenues of credit institutions in the region was far beyond reach of most of their competitors from developed countries and the financial systems they operated in slowly evolved, moving from state-owned monopolies towards market-based competition.

Before the evolution of the banking sectors of different Asian economies is described, it should be noted that the size and development stage of credit institutions in many countries in the region is very diverse. In high-income countries, banking assets exceed the worth of the home economy's GDP, while in less developed regions, banking sector remains relatively small.

First signals of the need for reforms came along with the Asian financial crisis of 1997. From the perspective of this chapter, the main reason for the crisis would be excess optimism in the region, resulting in major financial institution's exposure to high-risk investments. ${ }^{1}$ Authors also signal that the credited investments were misdirected, financing the development of non-traded goods and often into areas that were already overinvested. ${ }^{2}$ The consequence of this situation was that the creditors who were allowed to uptake major debts, became very sensitive to changes in market conditions and interest rates, in turn making the undercapitalized banking sector very fragile as well (see figure 6.1.). Early signals of recession resulted in severe runs on the banking system, threatening the stability of the entire financial system in the region.

Apart from implementing direct and interim measures addressing the crisis, countries in the region have undertaken a series of reforms of their financial systems. Some of them were very structural, where financial institutions were allowed to go into insolvency and disappear from the market (e.g. in Korea, Thailand and Indonesia). Those institutions who have prevailed needed to raise their capital substantially. Minimum capital requirement has been implemented but given the size of the gap that needed to be covered, public capital injections were also necessary. Finally, prudential supervision was strengthened and banks were forced to revise their credit scoring policies. ${ }^{3}$

Upscaling the standards of financial institutions was a process that took time. Its duration was disappointing at times, yet it should only be said that over the next years many financial institutions in the region was back on the path of fast

1 A. Berg [1999], The Asia Crisis: causes, policy responses and outcomes, IMF Working Paper, vol. 99 (138), Washington D.C., p. 5.

2 Ibidem.

3 X.M. Fu, Y.R. Lin, P. Molyneux [2015], Bank Competition, Efficiency and Liquidity Creation in Asia Pacific, Palgrave Macmillan, London, pp. 5-48. 
growth, despite the initial surge in GDP in the region. The global financial crisis of 2008 had a relatively low impact on the banks in the region - credit institutions were seen as stable and the national authorities were maintaining a reasonable amount of foreign reserves. ${ }^{4}$ Situation has changed after the failure of Lehman Brothers, when the drop in investor's trust resulted in a massive overpricing of risk in the region. ${ }^{5}$ Trade-dependent economies suffered additionally from the dry out of external sources of USD and then from a general drop in global demand. Nonetheless, after experiencing a time of recession (e.g. Singapore, Korea) or economic slowdown (e.g. China), the region started recovering already in 2009. This was yet another valuable experience in terms of severity of potential financial spill-overs that gave the necessary incentive to further reinforce and coordinate prudential supervision.

After the financial crisis Asian banks have intensified their cross-border activity. ${ }^{6}$ The total asset worth of the banking sector in the region has also grown substantially. ${ }^{7}$ It is worth to note that in 2015, revenues of the banks from Asia-Pacific accounted for as much as $46 \%$ of the global banking profit. ${ }^{8}$ When most Western banks have limited their activity in the region, Asian banks have clearly spotted their opportunity to extend their international presence.

\subsection{Major banking sectors in the region}

In terms of size and importance, China's banking sector has fast become the champion in the region with truly global aspirations. Developments in that country have been described in detail in previous section of this monography so the emphasis will be placed on other larger banking sectors in Asia.

Japan's banking sector, unlike most in the region, had to cope with many years of economic stagnation in the country that has brought down the profitability of

4 A. Filardo [2011], The Impact of the International Financial Crisis on Asia and the Pacific: Highlighting Monetary Policy Challenges from a Negative Assets Price Bubble Perspective, BIS Working Papers, vol. 356, Basel, p. 9.

5 Ibidem, p. 10.

6 E. Remolona, I. Shim [2015], The rise of regional banking in Asia and the Pacific, BIS Quarterly Review, https://www.bis.org/publ/qtrpdf/r_qt1509j.htm (accessed: 11.10.2019).

7 B. Kotanko, D. Woods, E.H. Lim, C. Pedersen, C.L. de Lanzos, M. Struder [2017], Asia Banking Agenda 2017, Oliver Wyman, https://www.oliverwyman.com/content/dam/oliver-wyman/ v2/events/2017/apr/Asia_Banking_Agenda_2017.pdf (accessed: 10.10.2019).

8 V. Hv, G. Lee, K. Rajendran, J. Sengupta [2016], Weathering the storm Asia-Pacific Banking Review, McKinsey\&Company, p. 4. 
credit institutions to very low levels. ${ }^{9}$ The entire financial system of Japan is still one of the most advanced in the world, that remained largely unaffected by the financial crisis of 2008, but the challenges ahead of it are much different than of its developing neighbours. ${ }^{10}$ The International Monetary Fund's (IMF) 2017 Financial System Stability Assessment has already signalled that the Japanese financial institutions are turning overseas to seek profitable investments that would compensate for ever-shrinking domestic demand. ${ }^{11}$

The banking sector of Singapore is another specific case in the region, as it constitutes a truly global financial centre, where foreign institutions are free to compete with the local credit institutions. Strong competition, however, not only did not marginalize the domestic institutions in Singapore that are internationally recognized, but it has also led to development of advanced financial services that has reinforced the country's position in international financial intermediation. ${ }^{12}$ Despite remarkably strong international ties, the financial sector of Singapore also remained stable both during the Asian banking crisis and the global financial crisis, which was attributed to strict prudential supervision and transparency of the regulatory authority that enshrined the investor's trust even at times of major turmoil. ${ }^{13}$

One example of an economy undergoing major changes in the financial sector over the past years can be Malaysia, where major restructuring plans have been implemented as of 2002 to build up financial stability. ${ }^{14}$ At the core of these reforms was a major central bank-orchestrated consolidation of 54 domestic credit institutions into ten larger players, capable of competing with foreign institutions and serving large consumers. ${ }^{15}$ This exercise, combined with careful oversight of commercial bank liquidity and capitalization by the central bank, have helped the Malaysian financial sector to remain stable during the global financial crisis of 2008. ${ }^{16}$ In 2019, reports by Malaysia's central bank have indicated high level of capitalization by the central banks and ample liquidity. ${ }^{17}$ It should also be noted

9 International Monetary Fund [2017], Japan. Financial System Stability Assessment, IMF Country Report, vol. 17/244, Washington D.C., p. 18.

10 R.S. Jones, M. Tsutsumi [2009], Financial Stability: Overcoming the Crisis and Improving the Efficiency of The Banking Sector in Japan, OECD Economies Department Working Papers, vol. 738, Paris, pp. 5-10.

11 International Monetary Fund [2017], op. cit., p. 6.

12 H.K. Chow-Tan, S.F. Pei [2019], Financial sector in Singapore, in: U. Voltz, P.J. Morgan, N. Yoshino (eds.), Routledge Handbook on Banking and Finance in Asia, Routledge, London, pp. 1-7.

13 Ibidem, p. 7.

14 Ch. Tin Fah, M. Ariff [2017], Competition in the Malaysia's Banking Industry, Quo Vadis, "International Journal of Economics and Management", vol. 11 (S3), p. 898.

15 R. Ahmad, M. Ariff, M. Skully [2005], Factors determining Mergers of banks in Malaysia's Banking Sector Reform, "Multinational Finance Journal”, vol. 11 (1), pp. 4-5.

16 Ch. Tin Fah, M. Ariff [2017], op. cit., p. 900.

17 Central Bank of Malaysia [2019], Financial Stability Review, http://www.bnm.gov.my/files/ publication/fsreview/en/2019/1h/en_fs_01.pdf?fbclid=IwAR3V8OcZgiX3d12FmC4hVC8Erqsk GSVgKwV1WcwNPrY8unzmzXyCOyOlsCQ (accessed: 15.10.2019), p. 9. 
that Malaysia is at the forefront of developing so-called Islamic banking, conducted according to Islamic law. ${ }^{18}$

Thai banking sector is a fairly good example of successful reform after the Asian banking crisis. Severity of the losses incurred in 1997 delivered substantial motivation to reorganize the financial system, since the country experienced a $40 \%$ drop in GDP per capita and nearly 75 billion USD of capital was withdrawn from the country over the period of five years. ${ }^{19}$ Through a tremendous effort of Thai authorities, trust in the financial system has been largely reinstated, although the initial restructuring took five years, followed by three phases of the so-called Financial Sector Master Plan, implemented over the period of 10 years. ${ }^{20}$ The IMF 2019 financial stability assessment has found the banking sector of Thailand resilient to even adverse shocks. ${ }^{21}$

Similarly to Thailand, Indonesian economy suffered tremendously from the Asian banking crisis. Indonesian authorities were criticized for their initial lack of dedication towards tackling the crisis or implementing the agreed programmes with the IMF, eventually increasing the costs to the economy, exceeding 80 billion USD. ${ }^{22}$ Nonetheless, the progress made until 2009 was sufficient for the country to last the global financial crisis without falling into recession. ${ }^{23}$ In 2019 the country's banking sector was reported to be well-capitalized, profitable and on the growth path. ${ }^{24}$

\subsection{Asian banking sector - status quo}

Over the past years the profitability of the Asian banks started declining. The slowdown could be due to several factors, including steady increase in capitalization in some countries (see examples on figure 6.1.), slower economic growth, increase in shadow banking and - in some cases - an increase in non-performing loans (NPLs).

18 S. Kunhbava [2012], Islamic Banking in Malaysia, "International Journal of Legal Information", vol. 40 (1-2), pp. 2-5.

19 O. Fratzscher [2002], Thailand. Financial Sector Strategy: Current Status and Future Priorities, The World Bank, Washington D.C., pp. 3-4.

20 R.A. Baxter [2010], Financial System Reform in Thailand, "Asia Focus" Federal Reserve Bank of San Francisco, http://www.frbsf.org/banking/files/july-2010-financial-system-reform-inthailand.pdf (accessed: 15.10.2019).

21 International Monetary Fund [2019], Thailand. Financial System Stability Assessment, IMF Country Report, vol. 19 (308), Washington D.C., pp. 9-10.

22 S. Radelet, J.D. Sachs [1998], The East Asian Financial Crisis: Diagnosis, Remedies, Prospects, "Brookings Papers on Economic Activity", vol. 1998 (1), pp. 119-120.

23 H. Hill [2012], The Best of Times and the Worst of Times: Indonesia and Economic Crises, Working Paper Australian National University, vol. 2012 (03), Canberra, p. 6.

24 International Monetary Fund [2019], Indonesia. Article IV Consultation - Press Release, IMF Country Report, vol. 19 (250), Washington D.C., p. 17. 


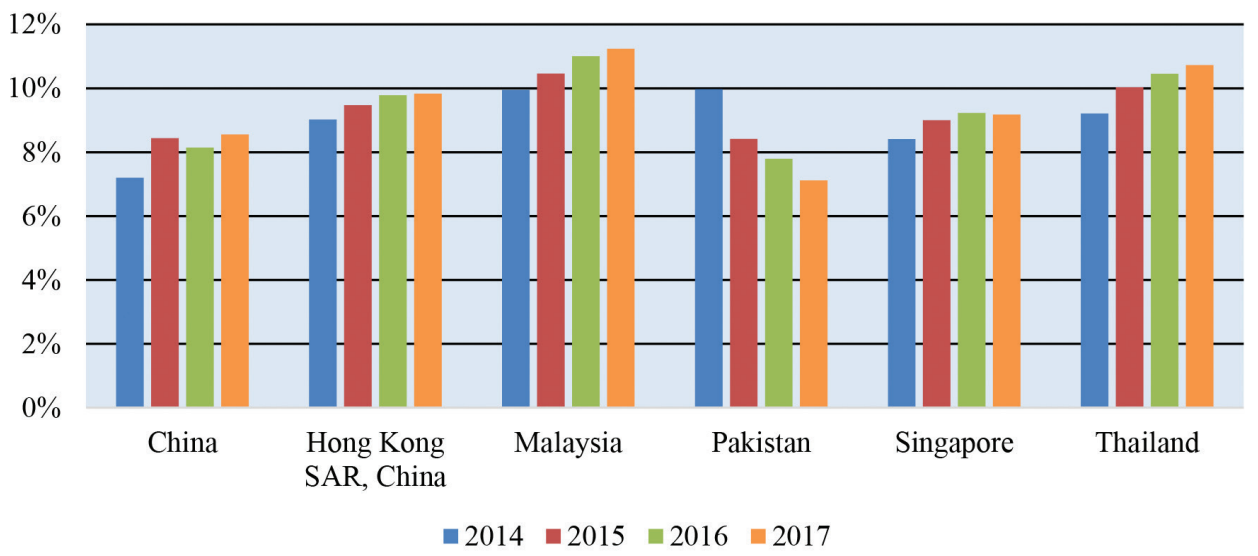

Figure 6.1. Bank capital to assets ratio (\%)

Source: own elaboration based on: World Bank [2014-2017], Database, https://data.worldbank.org/ (accessed: 19.10. 2019)

The trends in the share of non-performing loans was very different across the region and often stood in sharp contrast to each other, as could be observed on the example of India and Pakistan (figure 6.2.). While the share of threatened loans was mostly stable over the analysed years, McKinsey quotes that in practice, their share may force the regional credit institutions to raise as much as 600 billion USD of additional capital by 2020 to meet the capital adequacy ratios. ${ }^{25}$

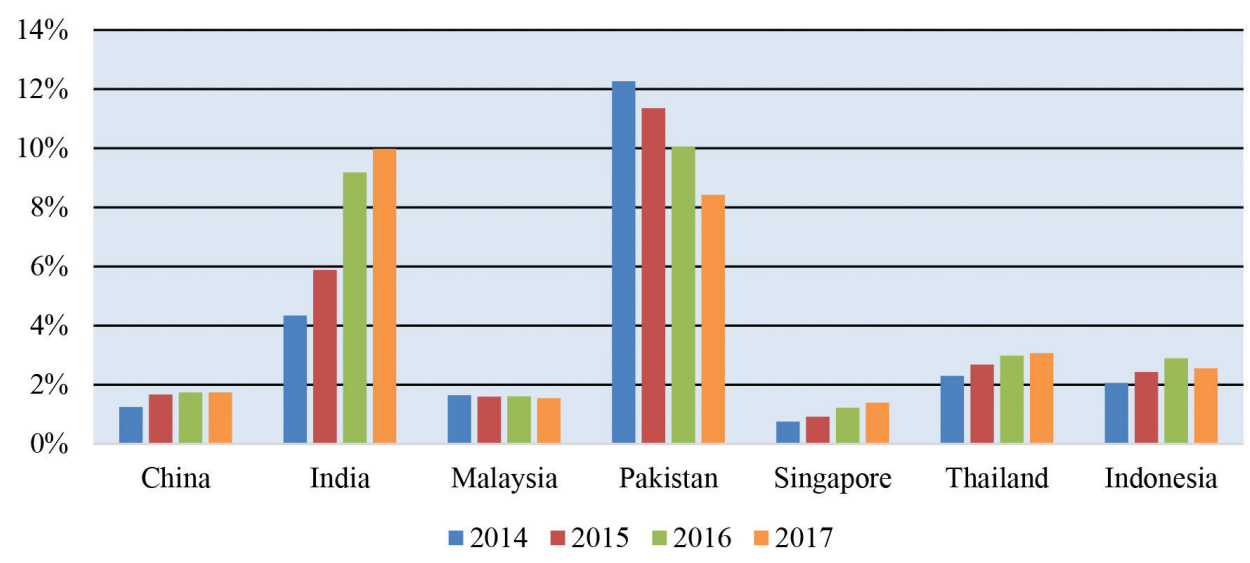

Figure 6.2. Bank NPLs (\% of gross total loans)

Source: own elaboration based on: World Bank [2014-2017], Database, https://data.worldbank.org/ (accessed: 19.10.2019)

25 V. Hv, G. Lee, K. Rajendran, J. Sengupta [2016], op. cit., p. 4. 
Apart India, the fluctuations in share of non-performing loans in general did not look alarming, not least for developing economies, where the average investment risk can be assumed to be higher than in developed countries. If the focus is narrowed further down to the three economies of Indonesia, Thailand and Malaysia, general performance of the banking sector does not look alarming either. The information on figure 6.3. show that despite the problems of the global financial institutions, banks in all three economies were on a constant growth path. While the overall income level was rather volatile over the period, the longer trend was clearly increasing.

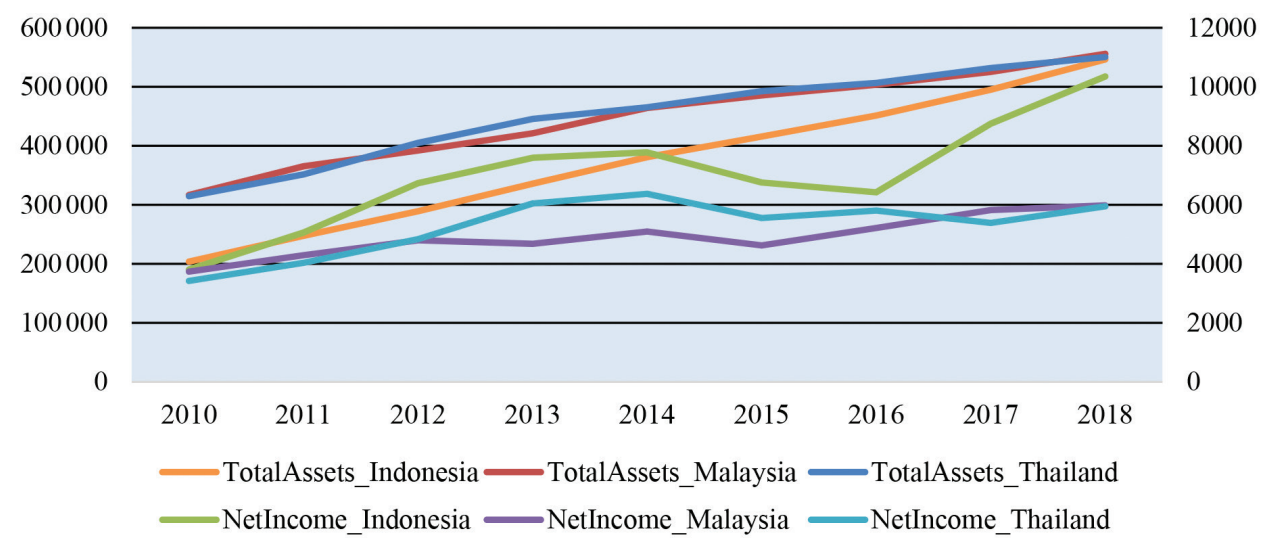

Figure 6.3. Total assets and net income of the chosen Asian banking sectors ( $m$ ln USD; net income on secondary axis)

Source: own elaboration based on: IMF Data [2010-2018], Financial Soundness Indicators, https://www.imf.org/en/Data (accessed: 19.10.2019)

\subsection{Asian banking sector - way forward}

Despite the good financial condition of the Asian banking sectors in aggregate, more recent reports on the Asian banking sector are rather pessimistic regarding their future. The years after the global financial crisis were a time of very dynamic credit growth. While this can be read as a sign of financial deepening, Basel Committee of Banking Supervision has signalled the issue of increasing credit to GDP gap - an indicator that policymakers are to use when setting the economiccycle related capital buffer (so-called countercyclical buffer). ${ }^{26}$ Such early-warning

26 M. Drehmann, K. Tsatsaronis [2014], The credit -to- GDP gap and countercyclical capital buffers: questions and answers, BIS Quarterly Review, https://www.bis.org/publ/qtrpdf/r_ qt1403g.pdf (accessed: 11.10.2019). 
indicator is to signal an upcoming financial distress and is calculated as deviations of the credit-to-GDP ratio from its long-term trend. ${ }^{27}$

Despite the relatively strong financial condition of the credit institutions in the region - Standard \& Poor signals that the local economies may be negatively affected by the escalating trade conflict between USA and China. ${ }^{28}$ McKinsey upholds its view from 2016, signalling that Asian banks may struggle to survive in an environment of lower economic growth and lower margins. ${ }^{29}$ The point on competition from non-banking financial service providers was also raised by Ernst \& Young in their report from 2019 where they highlighted the threat to traditional banking competitiveness. ${ }^{30}$

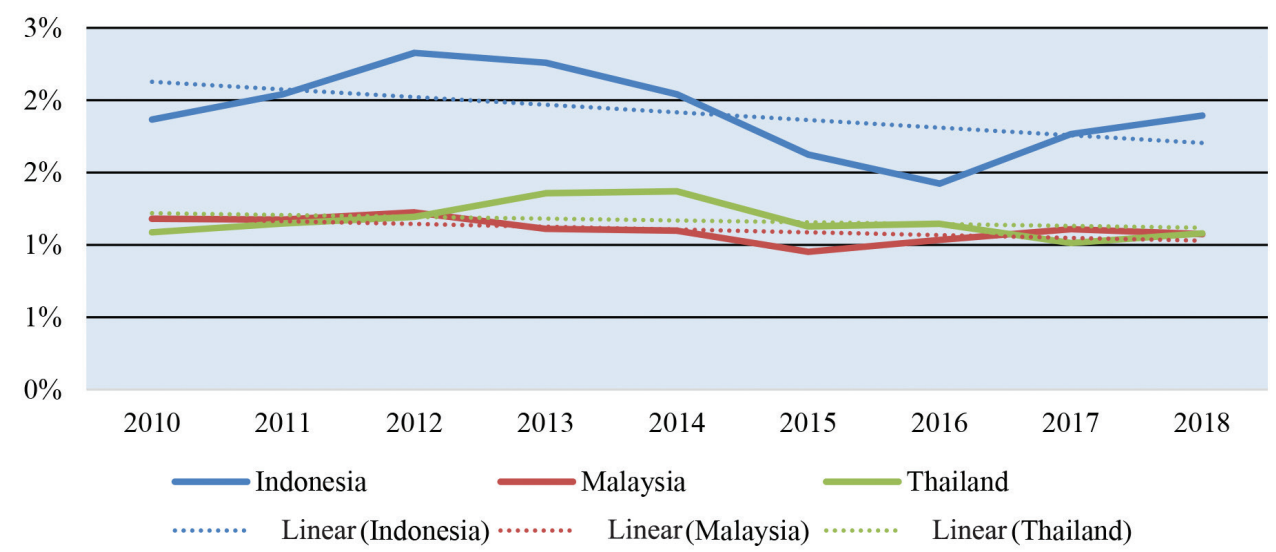

Figure 6.4. Average bank return-on-assets and the corresponding linear trends (\%) Source: own elaboration base on: IMF Data [2010-2018], Financial Soundness Indicators, https://www.imf.org/en/Data (accessed: 19.10. 2019)

If the information from figure 6.3. are analysed jointly, the long-term trend of the return-on-assets (ROA) over the same period, is in steady decline (figure 6.4.).

27 M. Behn, C. Detken, T.A. Peltonen, W. Schudel [2013], Setting Countercyclical Capital Buffers Based on Early Warning Models. Would it work?, ECB Working Paper Series, vol. 1604, Frankfurt am Main, pp. 1-2.

28 Standard \& Poor's Global [2018], Asia-Pacific Banking Outlook 2019 - Headwinds are picking up, https://www.spglobal.com/_assets/documents/corporate/apac-bankingoutlook2019_ ratings-.pdf?fbclid=IwAR1VH4hMp2-M3Hc4ux4uTKNNqctA5LnHyxTyrClqs3zuAi2jk9qvn5i07ll (accessed: 11.10.2019), p. 7.

29 J. Dahl, V. Giudici, J. Sengupta, S. Kim, E. Ng [2019], Asia-Pacific Banking Review 2019. Bracing for consolidation: the quest for scale, McKinsey \& Company, p. 2.

30 Ernst \& Young [2019], Banking in Asia-Pacific. Time to reinvent the digital landscape, https:// www.ey.com/Publication/vwLUAssets/EY-banking-in-asia-pacific-2019/\$File/EY-bankingin-asia-pacific-2019.pdf?fbclid=IwAR2irPmvAsJBxlpddeR-UBDnlukePHh0vNQfdwl1R1qvy cpjyjEOKZYDeGI (accessed: 11.10.2019), p. 3. 
This would confirm that the negative trend exists, yet this does not need to be surprising in itself, since the economies are maturing and competition becomes more intense. It is therefore the combined set of unfavourable conditions that altogether bring the rating agencies to the conclusion that the banking sectors of the developing Asian economies are heading towards a difficult time, in particular due to:

- slowing economic growth;

- stricter prudential requirements;

- high household debt;

- increasing market volatility.

As the economies mature and are slowing down, the banking industry is moving onto a different business reality, where the margins on customers are dropping and competition for new clients is on the rise. This new reality exerts pressure on the credit institutions to seek economies of scale that would protect their profitability and increase their resilience to bad loan write-offs. Therefore, the author agrees that the maturing economies in Asia are moving into a stage of intense mergers between the banks that are to help them endure in the new market conditions. Consolidation in the banking sectors should also be encouraged through the intensified competition from shadow-banking.

Besides the fundamental changes on the microeconomic side, the banks in Asia will also be facing significant changes in the macroeconomic environment. The entire region depends heavily on trade and exports to the largest markets of the World, including China, the EU and USA. ${ }^{31}$ This became particularly relevant due to an escalation in the trade war between China and USA. While the Asian Development Bank $(\mathrm{ADB})$ is rather positive about the general exports level from the developing countries in the region, it does not analyse in detail the consequences of an economic slowdown in China. ${ }^{32}$ It should also be noted that ADB does confirm the existence of collateral damage caused by the trade conflict on Asian economies and has expressed concerns over the potential drop in investor confidence in developing countries. From Asian credit institution's perspective, a notable slowdown in economic growth can result in serious problems, through an increase in NPL, drop in credit demand and shrinking capital inflows from abroad.

31 Deloitte [2019], Voice of Asia, https:/www2.deloitte.com/content/dam/insights/us/articles/ apac22437_voice-of-asia-5/DI_Voice-of-Asia-5.pdf?fbclid=IwAR0ylIrJM2l7OrLkj9qV6ilqomih XwF6RbTq2eJJdGRnWWg4Xk90Qde9EpE, pp. 15-22 (accessed: 11.10.2019).

32 A. Abiad, K. Baris, J.A. Bernabe et al. [2018], The impact of trade conflict on developing Asia, ADB Economics Working Paper Series, vol. 566, Manila, pp. 26-28. 


\section{Conclusions}

Steady maturation of the Asian economies brings their banking sectors to a new reality, where credit institutions need to make an effort to find a customer and to attract investors. The new reality also comes with the gradual opening of the sector to competition, not only from foreign banks but also from non-banking institutions providing financial services.

Currently, Asian credit institutions are in good financial condition and are wellcapitalized. Authorities in the region have made substantial progress in terms of prudential supervision and regulation of banks since the Asian financial crisis that was sufficient to protect their economies from major disturbances during the global financial crisis of 2008. Remarkable resilience of the Asian financial institutions should be appreciated by the investors especially in view of the challenges ahead of the entire sector.

Economic slowdown and growing competition have resulted in a steady drop in banking profitability. Profits should be expected to drop even further in view of the trade war between USA and China. In order to adjust to the new reality, credit institutions will need to merge their businesses and improve their competitiveness. Progress in this respect will constitute an interesting subject for further studies on the development of the banking industry in Asia and its interactions with the global financial system in the future. 


\section{Conclusions}

Considerations presented in this monography have emphasised the growing importance of Asia's economies on a global scale. Asian countries have reinforced the role they play in international trade and value chains, while their corporations have intensified investments in different countries around the world. The financial and energy sectors in the region have evolved and matured over the years and now have the potential to drive and sustain the economic growth in the future.

Changes in international trade of individual Asian countries strengthened their relationship with the global economy. However, the transformations were different in individual countries. China was a country where real exports increased tenfold when, in the same period, Japan's exports only doubled. During the last year of analysis, traditional statistics in individual cases overestimated export (Korea, Malaysia, Philippines, Singapore, Taipei, Thailand, Vietnam) and in some cases underestimated (China, Indonesia, Japan). Many Asian countries have become leading suppliers of semi-finished goods on the one hand, and on the other, they are operating as manufactures. Their position in global value chains verifies this. Observed adjustments were confirmed by the changes that have taken place in the most significant Asian transnational corporation.

Changes in the positions of Asian economies in international trade as well as in global value chains (presented in chapter 1) are closely associated with the implementation of new concepts for building international competitiveness by Asian transnational corporations (A-TNCs). Understanding the essence of modern models and principles of building international competitiveness in the $21^{\text {st }}$ century, including appreciating the growing importance of intellectual capital in the process of creating added value for enterprises, means the dynamic involvement of Asian entities in global value chains. One consequence is a significant improvement in the position of Asian corporations in international rankings as well as in the light of in-depth research using advanced synthetic measures assessing the ability to create added value (presented in chapter 2). It should be emphasized that the expansion of Asian corporations (including in the automotive and electronics sectors indicated as the most dynamically developing areas of Asia's non-financial expansion of TNCs) causes the activation of foreign direct investment transfers, which in turn is reflected in dynamic changes on the international mergers and acquisitions market - which illustrate the considerations of chapter 3 . 
The study conducted in the third chapter confirmed that from the beginning of the $21^{\text {st }}$ century the share of Chinese companies in the global economy has increased significantly, which was mainly associated with their growing share in the FDI. China's enterprises have aspired to be very active participants in the international mergers and acquisitions market. In particular, China's companies from sectors of the other finance, energy, automobiles and electronics played an important role in CBM\&A. They occupied a central place in the examined cross-industry CBM\&A network. It was closely connected with the changes that have taken place in the largest Asian transnational corporations, energy sector and banking sector.

Research on the role of energy in the development of China's economy (chapter 4) has shown a close correlation between this development and energy demand. Thus, they confirmed that the efficient functioning of the energy sector conditions this development. In all its phases, the demand for energy concerned mainly primary energy, although the more advanced stages are characterized by a clear increase in the importance of electricity. Studies have proved that the growing role of electricity in the Chinese economy is accompanied by a clear change in the structure of its generation. The share of coal in this structure, combustion of which is the main reason for environmental problems, and consequently health costs, has been significantly reduced. At the same time, new priorities have been identified in the development of China's energy, including in particular the widespread use of low-carbon energy generation technologies. It has been shown that this priority is implemented through the use of innovative technologies and solutions, a significant part of which is obtained as a result of mergers and acquisitions of foreign energy enterprises, especially in Europe.

Assessing the differentiation of China's and ASEAN member states' economic efficiency in terms of GDP while minimizing government consumption expenditure (chapter 5) showed that the highest measure of DEA efficiency in China with the lowest share of final consumption expenditure by general government in GDP was below the lowest average efficiency measure for ASEAN member states without Myanmar. The weak efficiency of government consumption expenditure in the creation of GDP in China against 9 ASEAN members states seems to be the crucial issue in the scope of a significance of government expenditure in the transformation of economic growth pattern from investment-led growth to consumption-led growth - can determine the development of strategic sectors (chapter 4) as well as the development of the entire country.

Decreasing profitability of credit institutions in Asia that was identified in chapter 6 signals that the banking sector has matured to a stage, where economic growth alone cannot sustain the revenue level it was experiencing in the past, and entities will have to compete intensively to retain their market share. The capability of the banks in the region to adapt to the new reality will impact the sustainability of Asia's economic expansion in the future. 


\section{References}

A Pole produces less for more - why such energy consumption? [2018], https:// wysokienapiecie.pl (accessed: 08.08.2018).

Abiad A., Baris K., Bernabe J.A. et al. [2018], The impact of trade conflict on developing Asia, ADB Economics Working Paper Series, vol. 566, Manila.

Ahmad R., Ariff M., Skully M. [2005], Factors determining Mergers of banks in Malaysia's Banking Sector Reform, "Multinational Finance Journal", vol. 11 (1).

Aller C., Ductor L., Herrerias M.J. [2015], The world trade network and the environment, "Energy Economics", vol. 52.

Al-Rodhan N.R.F., Stoudmann G. [2006], Definitions of Globalization: A Comprehensive Overview and a Proposed Definition, "Program on the Geopolitical Implications of Globalization and Transnational Security".

ASEAN Secretariat [2017], Overview of ASEAN China Relations, https://web.archive.org/ web/20180825002517; https://asean.org/storage/2016/01/Overview-of-ASEANChina-Rela tions-April-2017.pdf (accessed: 12.10.2019).

Bank of China [2013-2018], Annual Report, http://www.boc.cn/en/investor/ir3/ (accessed: 22.08.2019).

Banker R.D., Charnes A., Cooper W.W. [1984], Some Models for Estimating Technical and Scale Inefficiencies in Data Envelopment Analysis, "Management Science", vol. 30 (9).

Barro R.J. [1991], Economic Growth in a Cross Section of Countries, "Quarterly Journal of Economics", vol. CVI (425).

Baxter R.A. [2010], Financial System Reform in Thailand, "Asia Focus" Federal Reserve Bank of San Francisco, http://www.frbsf.org/banking/files/july-2010financial-system-reform-in-thailand.pdf (accessed: 15.10.2019).

Beer M., Ruth R.A. [1976], Employee Growth Through Performance Management, "Harvard Business Review", July-August.

Behn M., Detken C., Peltonen T.A., Schudel W. [2013], Setting Countercyclical Capital Buffers Based on Early Warning Models. Would it work?, ECB Working Paper Series, vol. 1604, Frankfurt am Main.

Berg A. [1999], The Asia Crisis: causes, policy responses and outcomes, IMF Working Paper, vol. 99 (138), Washington D.C. 
Bernstein P.L. [2007], Capital Ideas Evolving, John Wiley \& Sons, Inc., Hoboken, New Jersey.

The Best Global Brands [2008-2019], https:/www.interbrand.com/best-brands/ best-global-brands/2019/ranking, www.interbrand.com/Best_Global_Brands. aspx (accessed: 14.09.2019).

The Best Global Brands [2009-2019], https://www.interbrand.com/best-brands/ best-global-brands/2019/ranking, www.interbrand.com/Best_Global_Brands. aspx (accessed: 14.09.2019).

Boateng A., Qian W., Tianle Y. [2008], Cross-border MßAs by Chinese firms: An analysis of strategic motives and performance, "Thunderbird International Business Review", vol. 50 (4).

BP Statistical Review of World Energy 2019 [2019], https://www.bp.com (accessed: 30.09.2019).

Central Bank of Malaysia [2019], Financial Stability Review, http://www.bnm.gov. my/files/publication/fsreview/en/2019/1h/en_fs_01.pdf?fbclid=IwAR3V8O cZgiX3d12FmC4hVC8ErqskGSVgKwV1WcwNPrY8unzmzXyCOyOlsCQ (accessed: 15.10.2019).

Charnes A., Cooper W.W., Rhodes E. [1978], Measuring the efficiency of decision making units, "European Journal of Operational Research", vol. 2 (6).

Charnes A., Cooper W.W., Golany B., Seiford L.M., Stutz J. [1985], Fundations of DEA for Pareto-Koopmans Efficient Empirical Production Function, "Journal of Economics", vol. 30 (1-2).

China - a challenge for the world? [2015], http://www.chronmyklimat.pl (accessed: 22.07.2019).

China Construction Bank [2013-2018], Annual Report, http://www.ccb.com/en/ newinvestor/annals.html (accessed: 22.08.2019).

China power system transformation. Assessing the benefit of optimised operations and advanced flexibility options [2019], International Energy Agency, https:// webstore.iea.org (accessed: 14.10.2019).

China: Growing import volumes of LNG highlight China's rising energy import dependency [2019], The Oxford Institute for Energy Studies, https://www.oxfor denergy.org (accessed: 24.06.2019).

China's global renewable expansion [2017], Institute for Energy Economics and Financial Analysis, http://ieefa.org (accessed: 21.10.2019).

Chow-Tan H.K., Pei S.F. [2019], Financial sector in Singapore, in: U. Voltz, P.J. Morgan, N. Yoshino (eds.), Routledge Handbook on Banking and Finance in Asia, Routledge, London.

Clean Energy investment trends [2018], Bloomberg New Energy Finance, https:// data.bloomberglp.com (accessed: 16.04.2019).

Cooray A.V. [2009], Government expenditure, governance and economic growth, "Comparative Economic Studies", vol. 51 (3). 
Dahl J., Giudici V., Sengupta J., Kim S., Ng E. [2019], Asia-Pacific Banking Review 2019. Bracing for consolidation: the quest for scale, McKinsey \& Company.

De Benedictis L., Nenci S., Santoni G., Tajoli L., Vicarelli C. [2014], Network analysis of world trade using the BACI-CEPII dataset, "Global Economy Journal", vol. $14(3 / 4)$.

Debreu G. [1951], The Coefficient of Recourse Utilization, "Econometrica", vol. 19 (3).

Dedrick J., Kraemer K.L., Linden G. [2008], Who Profits from Innovationin Global Value Chains?: A Study of the iPod and Notebook PCs, "Industry Studies", Boston.

Deloitte [2019], Voice of Asia, https://www2.deloitte.com/content/dam/insights/ us/articles/apac22437_voice-of-asia-5/DI_Voice-of-Asia-5.pdf?fbclid=IwA R0ylIrJM217OrLkj9qV6ilqomihXwF6RbTq2eJJdGRnWWg4 Xk9OQde9EpE (accessed: 11.10.2019).

Dicken P. [2007], Global Shift: Mapping the Changing Contours of the World Economy, Sage Publications Ltd, London.

Domagała A. [2007], Metoda Data Envelopment Analysis jako narzędzie badania względnej efektywności technicznej, "Operations Research and Decisions", vol. 3-4.

Domański C. [2001], Analiza korelacji i regresji, in: C. Domański (ed.), Metody statystyczne. Teoria i zadania, Wydawnictwo Uniwersytetu Łódzkiego, Łódź.

Drehmann M., Tsatsaronis K. [2014], The credit-to-GDP gap and countercyclical capital buffers: questions and answers, BIS Quarterly Review, https://www.bis. $\mathrm{org} / \mathrm{publ} / \mathrm{qtrpdf} / \mathrm{rqt} 1403 \mathrm{~g} . \mathrm{pdf}$ (accessed: 11.10.2019).

Easterly W., Rebelo S. [1993], Fiscal policy and economic growth. An empirical investigation, "Journal of Monetary Economics", vol. 32 (3).

Elliott M., Golub B., Jackson M.O. [2014], Financial networks and contagion, "American Economic Review", vol. 104 (10).

Energy efficiency 2018 [2018], International Energy Agency, https://www.iea.org (accessed: 24.07.2019).

Ernst \& Young [2019], Banking in Asia-Pacific. Time to reinvent the digital landscape, https://www.ey.com/Publication/vwLUAssets/EY-banking-in-asia-pacific-2019/\$ File/EY-banking-in-asia-pacific-2019.pdf?fbclid=IwAR2irPmvAsJBxlpddeRUBDnIukePH h0vNQfdwI1R1qvycpjyjEOKZYDeGI (accessed: 11.10.2019).

Ernst D. [2011], China's Innovation Policy Is a Wake-Up Call for America, Asia Pacific Issues, vol. 100.

Fäare R., Grosskopf S., Lovell C.A.K. [1985], The Measurement of Efficiency of Production, Kluwer Academic Publishers, Boston.

Fang C. [2016], China's economic growth prospects from demographic dividend to reform dividend, E. Elgar Publishing, Cheltenham (UK), Northampton (MA, USA).

Farell M.J. [1957], The Measurement of Productive Efficiency, "Journal of the Royal Statistical Society", series A, vol. 120 (3). 
Feng Y.J., Lu H., Bi K. [2004], An AHP/DEA method for measurement of the efficiency of R\&D management activities in universities, "International Transactions in Operational Research", vol. 11 (2).

Feruś A. [2006], Zastosowanie metody DEA do określania poziomu ryzyka kredytowego przedsiębiorstw, "Bank \& Credit", vol. 7.

Filardo A. [2011], The Impact of the International Financial Crisis on Asia and the Pacific: Highlighting Monetary Policy Challenges from a Negative Assets Price Bubble Perspective, BIS Working Papers, vol. 356, Basel.

Fölster S., Henrekson M. [2001], Growth Effects of Government Expenditure and Taxation in Rich Countries, "European Economic Review", vol. 45 (8).

The Forbes Global 2000 [2006-2019], The World's Biggest Public Companies, http:// www.forbes.com /lists/.html; https://www.forbes.com/global2000/list (accessed: 12.06.2019).

Fratzscher O. [2002], Thailand. Financial Sector Strategy: Current Status and Future Priorities, The World Bank, Washington D.C.

Fu X.M., Lin Y.R., Molyneux P. [2015], Bank Competition, Efficiency and Liquidity Creation in Asia Pacific, Palgrave Macmillan, London.

Fuks K., Kawa A., Pierański B. [2014], Zastosowanie mierników SNA w analizie sieci przedsiębiorstw, "Marketing i Rynek", vol. 5 (CD).

Gaburro G., O’Boyle E.J. [2003], Norms for evaluating economic globalization, "International Journal of Social Economics", vol. 30 (1/2).

Gacek Ł. [2012], China’s energy security, Księgarnia Akademicka, Kraków.

Gacek Ł. [2015], Greenenergy in China, Wydawnictwo Uniwersytetu Jagielońskiego, Kraków.

Gereffi G., Humphrey J., Sturgeon T. [2005], The governance of global value chains, "Review of International Political Economy", 12.01 February.

Gereffi G., Humphrey J., Kaplinsky R., Sturgeon T.J. [2001], The Value of Value Chains: Spreading the Gains from Globalisation, "IDS Bulletin", vol. 32 (3), Institute of Development Studies.

Ghura D. [1995], Macro Policies, External Forces, and Economic Growth in SubSaharan Africa, "Economic Development and Cultural Change", vol. 43 (4).

The Global 2000 [2006], The World's Biggest Public Companies, http://www.forbes. com/lists/2006/18/Rank_3.html (accessed: 06.03.2010).

The Global 2000 [2012], http://www.forbes.pl/rankingi/najwieksze-firmy-swia ta-2012,26185 (accessed: 18.04.2012).

The Global 2000 [2018], https://www.forbes.com/global2000/list (accessed: 15.03.2019). Global energy statistical yearbook 2019 [2019], https://yearbook.enerdata.net (accessed: 21.09.2019).

Gostomski E., Michalski T. [2017], Czy następuje odwrót od globalizacji?, in: A. Gorynia (ed.), Nowe kraje członkowskie UE wobec procesów globalizacji. Źródła konkurencyjności, Wydział Ekonomiczno-Informatyczny w Wilnie, Uniwersytet w Białymstoku, Vilnius. 
Góralczyk B. [2019], China's energy geostrategy, https://www.cire.pl (accessed: 26.09.2019).

Gregoriou A., Ghosh S. [2006], On the Composition of Government Spending, Optimal Fiscal Policy, and Endogenous Growth: Theory and Evidence, https://www. brunel.ac.uk/_data/assets/pdf_file/0010/84475/ 0619.pdf, pp. 1-28 (accessed: 12.09.2019).

Gu L., Reed W.R. [2013], Chinese overseas M\&A performance and the go global policy, "Economics of Transition", vol. 21 (1).

Gupta R. [2018], The impact of government expenditure on economic growth in $\mathrm{Ne}$ pal, https://papers.ssrn.com/sol3/papers.cfm?abstract_id=3099218 (accessed: 12.09.2019).

Hasnul A.G. [2016], The effects of government expenditure on economic growth: the case of Malaysia, "MPRA Paper", vol. 71254, https://mpra.ub.uni-muenchen. de/71254/ (accessed: 12.09.2019).

Helta M. [2009], Zastosowanie metody DEA do opracowania rankingu efektywności spółek Agencji Nieruchomości Rolnych w 2006 roku, "Annals of Agricultural Sciences", series G, vol. 96 (3).

Hill H. [2012], The Best of Times and the Worst of Times: Indonesia and Economic Crises, Working Paper Australian National University, vol. 2012 (03), Canberra.

Hoddy E. [2018], Critical realism in empirical research: employing techniques from Grounded theory Methodology, "International Journal of Social Research Methodology", vol. 22.

$\mathrm{Hu}$ N., Zhang Y.I., Tan S. [2016], Determinants of Chinese cross-border M\&As, "Annals of Economics and Finance", vol. 17 (1).

Hurmelinna-Laukkanen P., Nätti S. [2018], Orchestrator types, roles and capabilities - A framework for innovation networks, "Industrial Marketing Management", vol. 74.

Hv V., Lee G., Rajendran K., Sengupta J. [2016], Weathering the storm Asia-Pacific Banking Review, McKinsey \& Company.

IEA: China can be a leader in the construction of nuclear power plants [2018], https://www.cire.pl (accessed: 23.06.2019).

IEA: the closure of nuclear power plants threatens global plans to reduce $\mathrm{CO}_{2}$ emissions [2017], https://www.cire.pl (accessed: 23.09.2019).

In Germany, the purchase by the Chinese of shares in the TSO of energy was thwarted [2018], https://www.cire.pl (accessed: 27.09.2019).

In search of lost power. China from a poor country has become a global superpower [2019], https://forsal.pl (accessed: 22.04.2019).

International Monetary Fund [2010-2018], Financial Soundness Indicators, https:// www.imf.org/en/Data (accessed: 19.10. 2019).

International Monetary Fund [2017], Japan. Financial System Stability Assessment, IMF Country Report, vol. 17 (244), Washington D.C. 
International Monetary Fund [2019], Indonesia. Article IV Consultation - Press Release, IMF Country Report, vol. 19 (250), Washington D.C.

International Monetary Fund [2019], Thailand. Financial System Stability Assessment, IMF Country Report, vol. 19 (308), Washington D.C.

Jacobs R. [2001], Alternative methods to examine hospital efficiency: data envelopment analysis and stochastic frontier analysis, "Health Care Management Science", vol. 4 (2).

Jiranyakul K. [2013], The relation between government expenditures and economic growth in Thailand, "MPRA Paper", vol. 46070, https://mpra.ub.uni-muenchen. de/46070/ (accessed: 12.09.2019).

Johnson G., Scholes K. [1999], Exploring Corporate Strategy, Prentice Hall Europe, London.

Jones R.S., Tsutsumi M. [2009], Financial Stability: Overcoming the Crisis and Improving the Efficiency of The Banking Sector in Japan, OECD Economis Departament Working Papers, vol. 738, Paris.

Jóźwiak J., Podgórski J. [2009], Statystyka od podstaw, PWE, Warszawa.

Kase K., Slocum A., Zhang Y. [2011], Asian versus Western Management Thinking: Its Culture-Bound Nature, "The Nonaka Series on Knowledge and Innovation", Palgrave Macmillan, UK.

Klimas P. [2015], Structural Face of Competition, Cooperation and Coopetition Inside Business Networks, "Argumenta Oeconomica", vol. 1 (34).

Klimek A [2013]., Efekty międzynarodowych fuzji i przejęć dokonanych przez korporacje transnarodowe $z$ Chin, "International Journal of Management and Economics", vol. 38.

Klimek A. [2016], Cross-border mergers and acquisitions by Chinese state-controlled enterprises, "Prace Naukowe Uniwersytetu Ekonomicznego we Wrocławiu", vol. 447.

Koetsier J. [2019], Apple Most-Admired Global Company, Says Fortune, https:// www.forbes.com/sites/johnkoetsier/2019/01/22/ (accessed: 02.09.2019).

Koopman R., Powers W., Wang Z., Wei S.J. [2010], Give Credit Where Credit Is Due: Tracing Value Added in Global Production Chains, "NBER Working Paper", vol. 16426.

Korn Ferry Institute [2018], Reports \& Insights FORTUNE World's Most Admired Companies, January 19, 2018, https://www.kornferry.com/institute/fortuneworlds-most-admired-companies-2018 (accessed: 09.09.2019).

Kotanko B., Woods D., Lim E.H., Pedersen C., de Lanzos C.L., Struder M. [2017], Asia Banking Agenda 2017, Oliver Wyman, https://www.oliverwyman.com/ content/dam/oliver-wyman/v2/events/2017/apr/Asia_Bank ing_Agenda_2017. pdf (accessed: 10.10.2019).

Kucharski A. [2014], Metoda DEA w ocenie efektywności gospodarczej, Wydawnictwo Uniwersytetu Łódzkiego, Łódź. 
Kunhbava S. [2012], Islamic Banking in Malaysia, "International Journal of Legal Information", vol. 40 (1-2).

Lahirushan K.P.K.S., Gunasekara W.G.V. [2015], The Impact of Government Expenditure on Economic Growth: A Study of Asian Countries, "International Journal of Humanities and Social Sciences", vol. 9 (9).

Lee H., Sohn I. [2016], Big Data w przemyśle. Jak wykorzystać analizę danych do optymalizacji kosztów procesów?, Wydawnictwo Naukowe PWN, Warszawa.

Leong C., Tan B., Xiao X., Ter Chian Tan F., Sun Y. [2017], Nurturing a FinTech ecosystem: The case of a youth microloan startup in China, "International Journal of Information Management", vol. 37.

Lequiller F., Blades D. [2014], Understanding National Accounts: Second Edition, OECD Publishing, Paris.

Linden G., Kraemer K.L., Dedrick J. [2009], Who captures value in a global innovation network?: the case of Apple's iPod, "Communications of the ACM", vol. 52 (3).

Loizides J., Vamvoukas G. [2005], Government expenditure andeconomic growth: evidence from trivariate causality testing, "Journal of Applied Economics", vol. $8(1)$.

Lou Y.D. [2005], Toward Coopetition within a Multinational Enterprise, "Journal of World Business" 2005, vol. 40 (1).

Main links between energy and the economy [2014], https://ziemianarozdrozu.pl (accessed: 20.09.2019).

Mayer-Schänberger V., Cukier K. [2017], BIG DATA. A revolution that will change our thinking, work and life, MT Biznes, Warszawa.

Mazurek S. [2016], Identyfikacja sieci w gospodarce, "Prace Naukowe Uniwersytetu Ekonomicznego we Wrocławiu", vol. 448.

Mirc N. [2015], Merging networks - contributions and challenges of social network analysis to study mergers and acquisitions, in: A. Risberg, D. King, O. Meglio (eds.), Routledge Companion on Mergers and Acquisitions, Routledge, London.

Morisson W.M. [2014], China's economic rise: history, trends, challenges and implications for the United States, Congressional Research Service, Washington, D.C.

MSCI World Quality Index [2019], https://www.msci.com/documents/10199/ (accessed: 30.09.2019).

Murphy A., Ponciano J., Hansen S., Touryalai H. [2000], Global 2000. The World's Largest Public Companies, May 15, 2019, https://www.forbes.com/ global2000/\#6686b98f335d (accessed: 14.09.2019).

Myers J.L., Well A.D. [2003], Research Design and Statistical Analysis [2nd ed.], Lawrence Erlbaum Associates Publishers, New Jersey-London.

Nacewska-Twardowska A. [2018], Atlas handlu wartościa dodaną. Eksport, Wydawnictwo Uniwersytetu Łódzkiego, Łódź.

Nikitin P.V., Elliott J.E. [2000], Freedom and the Market, "The Forum for Social Economics", Fall. 
Nowakowski R. [2019], Sustainable energy transformation in Poland, or how can conventional sources support the rapid development of renewable energy?, Polish Energy Brief, vol. 2.

OECD [2013], Interconnected Economies: Benefiting from global value chains. Synthesis Report, Paris.

OECD [2014], National Accounts at a Glance 2014, OECD Publishing, Paris.

OECD-WTO TiVA Database [2016], Trade in Value-Added and Global Value Chains profiles. Explanatory notes, http://www.oecd.org/industry/ind/measuringtradeinvalue-addedanoecdwtojointinitiative.htm (accessed: 22.10.2016).

OECD-WTO TiVA Database [2019], https://www.oecd.org/sti/ind/measuringtrade-in-value-added.htm (accessed: 11.08.2019).

Pająk K., Mazurkiewicz J., Lis P. [2015], China's Road to a Low Carbon Economy, in: J. Marszałek-Kanwa, K. Pająk (eds.), Energy Policy of Asia-Pacific States, Wydawnictwo Adam Marszałek, Toruń.

Popławski K. [2019], Chinese in German energy networks?, https://www.osw.waw. pl (accessed: 21.02.2019).

Porter M.E., Kramer M.R. [2011], The Big Idea: Creating Shared Value, "Harvard Business Review", vol. 89 (1-2).

Prospects for distributed energy systems in China [2017], IEA, https://www.iea.org, (accessed: 19.09.2019).

Pugna I.B., Albescu F., Babeanu D. [2009], The Role of Business Intelligence in Business Performance Management, "Annals of the University of Oradea, Economic Science Series", vol. 18 (4).

Radelet S., Sachs J.D. [1998], The East Asian Financial Crisis: Diagnosis, Remedies, Prospects, "Brookings Papers on Economic Activity", vol. 1998 (1).

Radomska E. [2018], Chińskie bezpośrednie inwestycje zagraniczne w Unii Europejskiej - kontrowersje i wyzwania, "KNUV", vol. 2 (56).

Razzolini L., Shughart II W.F. [1997], On the [Relative] Unimportance of a Balanced Budget, "Public Choice", vol. 90 (1/4).

Rehman J., Iqbal A., Siddiqi M.W. [2010], Cointegration-Causality Analysis between Public Expenditures and Economic Growth in Pakistan, "European Journal of Social Sciences", vol. 13 (4).

Remolona E., Shim I. [2015], The rise of regional banking in Asia and the Pacific, BIS Quarterly Review, https://www.bis.org/publ/qtrpdf/r_qt1509j.htm (accessed: 11.10.2019).

Ritala P., Golnam A., Wegmann A. [2014], Coopetition-based business models: The case of Amazon.com., "Industrial Marketing Management", vol. 43.

The role of gas in today's energy transitions [2019], IEA, https://webstore.iea.org (accessed: 15.06.2019).

Rosińska M. [2008], Procesy globalizacji jako geneza kreowania globalnej przestrzeni gospodarczej, "Acta Universitatis Lodziensis. Folia Geographica SocioOeconomica", vol. 9. 
Rosińska-Bukowska M. [2012], Rozwój globalnych sieci biznesowych jako strategia konkurencyjna korporacji transnarodowych, Wydawnictwo Uniwersytetu Łódzkiego, Łódź.

Rosińska-Bukowska M. [2016], The Model of Competitiveness Assessment of Coopetition Network Systems - Competition and Cooperation of Enterprises in the Global Economy, "Journal of Economics and Management", vol. 24 (2).

Rosińska-Bukowska M. [2017], Strategic changes in transnational corporation as an adjustment to the challenges of the $21^{\text {st }}$ Century, "Entrepreneurial Business and Economics Review", vol. 5 (2).

Rosińska-Bukowska M. [2019], Human Capital and Intellectual Capital in Modern International Business - Based on Studies of the Strategies of Transnational Corporations, "Comparative Economic Research", vol. 22 (2).

Roudometof V. [2016], Theorizing glocalization: Three interpretations, "European Journal of Social Theory", vol. 19 (3).

Sajnóg A. [2015], Comparative Analysis of Economic Efficiency of Polish and German Listed Companies, "Oeconomia Copernicana”, vol. 6 (2).

Sajnóg A., Sosnowski T. [2015], Efektywność realizacji procesów dezinwestycji funduszy private equity na GPW w Warszawie, "Studies and Works College of Management and Finance", vol. 143.

Sánchez Díez A., Galaso Reca P., García de la Cruz J.M. [2017], Mergers and acquisitions carried out by Spanish firms in Latin America: a network analysis study, “CEPAL Review”, vol. 2016 (120).

Skłodowska M. [2019], The appetite for electricity is growing. We are not keeping up with production, https://www.money.pl (accessed: 30.03.2019).

Sobczyk M. [2010], Statystyka opisowa, C. H. Beck, Warszawa.

Srivastava M., Tranklin A., Martinette L. [2013], Building a Sustainable Competitive Advantage, "Journal of Technology Management and Innovation", vol. 8 (2).

Standard \& Poor's Global [2018], Asia-Pacific Banking Outlook 2019 - Headwinds are picking up, https://www.spglobal.com/_assets/documents/corporate/apacbankingoutlook2019_ratings-.pdf?fbclid=IwAR1VH4hMp2-M3Hc4ux4uT KNNqctA5LnHyxTyrClqs3zuAi2jk9qvn5i07lI (accessed: 11.10.2019).

Sturgeon T. [2009], From Commodity Chains to Value Chains: Interdisciplinary Theory Building in an Age of Globalization, in: J. Bair (ed.), Frontiers of Commodity Chain Research, Stanford University Press.

Sueyoshi T., Goto M. [2012], Data envelopment analysis for environmental assessment: Comparison between public and private ownership in petroleum industry, "European Journal of Operational Research", vol. 216 (3).

System of National Accounts 2008 [2009], EC, IMF, OECD, UN, WB, New York.

Tempest R. [1996], Barbie and the World Economy, "Los Angeles Times”, 22.10.1996, https://www.latimes.com/archives/la-xpm-1996-09-22-mn-46610-story.html (accessed: 10.08.2019). 
The Top 100 Brands [2006-2007], Special Report, BusinessWeek, August 6, 2007. The Top 100 Global Brands [2006-2019], https://www.interbrand.com/best-brands/ best-global-brands/2018/ranking, www.interbrand.com/Best_Global_Brands. aspx (accessed: 12.06.2019).

The World Investment Report [2008-2019], The world's top 100 non-financial MNEs, ranked by foreign assets, https://unctad.org/en/Pages/DIAE/WorldInvestmentReport/Annex-Tables.aspx (accessed: 12.06.2019).

The World's Most Admired Companies (MAC) [2006], https://money.cnn.com/magazines/fortune/globalmostadmired/full_list/index.html (accessed: 12.06.2019).

Tin Fah Ch., Ariff M. [2017], Competition in the Malaysia's Banking Industry, Quo Vadis, "International Journal of Economics and Management", vol. 11 (S3).

Toffler A. [1985], Trzecia Fala, PIW, Warszawa.

Tsai W.-H., Lee H.-L., Yang C.-H., Huang C.-C. [2016], Input-Output Analysis for Sustainability by Using DEA Method: A Comparison Study between European and Asian Countries, "Sustainability", vol. 8 (12), https://www.mdpi.com/20711050/8/12/1230 (accessed: 04.09.2019).

UNCTAD [2013], World Investment Report 2013: Global Value Chains: Investment and Trade for Development, New York and Geneva.

UNCTAD [2015], Tracing the value added: product-level case studies in China, New York and Geneva.

UNCTAD, World Investment Report: Annex Tables 2019, www.unctad.org/fdista tistics (accessed: 16.09.2019).

United Nations [2002], Manual on Statistics of International Trade in Services, Eurostat, IMF, OECD, UN, UNCTAD, WTO, 2002 - Annex II, Glossary, http://unstats. un.org/unsd/publication/Seriesm/Seriesm_86e.pdf (accessed: 07.08.2019).

Van den Bergh J.C.J.M. [2009], The GDP paradox, "Journal of Economic Psychology", vol. 30.

Vitali S., Battiston S. [2014], The community structure of the global corporate network, "PLoS ONE", vol. 9 (8).

Wasiński M. [2018], Prospects for the development of renewable energy sources in the USA, https://www.cire.pl (accessed: 21.07.2019).

Wilkins M. [1998], Multinational Corporations. An Historical Account, in: R. Kozul-Wright, R. Rowthorn (eds.), Transnational Corporations and the World Economy, Wider-McMillan Press-St. Martin's Press, London-New York.

Will Chinese harm the diversification of gas supplies to Poland? [2019], https://www. energetyka24.com (accessed: 27.02.2019).

World Bank [1960-2018], Data - GDP (current US\$), https://data.worldbank.org/ indicator/ny.gdp.mktp.cd (accessed: 12.10.2019).

World Bank [2014-2017], Database, https://data.worldbank.org/ (accessed: 19.10. 2019).

World Bank [2017], Balancing Act. East Asia and Pacific Economic Update, World Bank Group, Washington D.C. 
World Bank [2017], China - Systematic Country Diagnosis: towards a more inclusive and sustainable development, World Bank Group, Washington, D.C.

World Economic Forum [2012], The Shifting Geography of Global Value Chains: Implications for Developing Countries and Trade Policy, Global Agenda Council on the Global Trade System.

World energy outlook 2018 [2018], OECD/IEA, https://www.iea.org (accessed: 11.09.2019).

World Trade Organization [2014], World Trade Report 2014. Trade and development: recent trends and the role of the WTO, Geneva.

Yang S., Keller F.B., Zheng L. [2017], Social network analysis: methods and examples, Sage Publications, Los Angeles, CA.

Ylvinger S. [2000], Essays on Production Performance Assessment, "Umeå Economic Studies", vol. 531. 



\section{List of figures}

Figure 1.1. Comparison of traditional and value added trade

Figure 1.2. Comparison of gross trade statistics and value added trade statistics from figure 1.1.

(in EUR)

Figure 1.3. Comparison of gross trade and value added trade in a geographical context........

Figure 1.4. Stan Shih's smile curve

Figure 1.5. Division of gross exports into domestic and foreign value added along with links up and down the supply chain

Figure 1.6. Traditional and value added exports (DVA) of selected Asian countries in 1995-2016 (bln USD)

Figure 1.7. Index of the share of domestic value added in gross exports of selected Asian countries in 1995-2016

Figure 1.8. General index of participation in the global value chain and position index in the global value chains of selected Asian countries in 2016

Figure 1.9. China's backward and forward participation in the GVC in 1995-2016

Figure 1.10. General indexes of participation and position in the global value chains of China in 1995-2016

Figure 1.11. Backward and forward participation of South Korea in GVC in 1995-2016 .....

Figure 1.12. General indexes of participation and position in the global value chains of South Korea in 1995-2016

Figure 1.13. Japan's backward and forward participation in the GVC in 1995-2016

Figure 1.14. General indexes of participation and position in the global value chains of Japan

in 1995-2016

Figure 2.1. The system of the attributes of transnational corporations ......

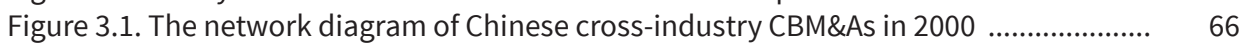

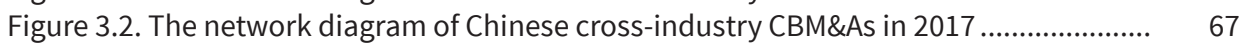

Figure 3.3. Main target regions of Chinese CBM\&As in 2000-2017 (percentage share) ........ 69

Figure 3.4. The average level of degree and eigenvector centrality for the main nodes forming the Chinese CBM\&As network in the period 2000-2017

Figure 3.5. The average level of closeness centrality for the main nodes forming the Chinese CBM\&As network in the period 2000-2017

Figure 4.1. Word growth in oil, energy and GDP

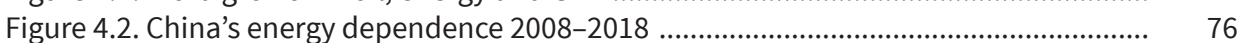

Figure 4.3. Investments in clean energy technologies ......................................................... 84

Figure 5.1. General government final consumption expenditure in China and nine ASEAN member states in the years 2008-2017 (\% of GDP) . 
Figure 5.3. Annual mean measure of DEA efficiency in China and nine ASEAN member states $[-]$.....

Figure 5.4. DEA efficiency measure in China and nine ASEAN member states in the years 2008-2017 [-] .......................................................................................... 108

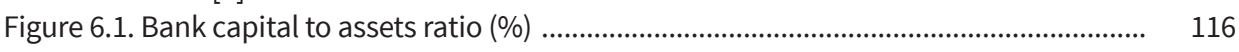

Figure 6.2. Bank NPLs (\% of gross total loans) ......................................................................... 116

Figure 6.3. Total assets and net income of the chosen Asian banking sectors ( $\mathrm{mln}$ USD; net income on secondary axis) ........................................................................................ 117

Figure 6.4. Average bank return-on-assets and the corresponding linear trends (\%) ......... 118 


\section{List of tables}

Table 1.1. Average annual increase in gross exports in 1990-2018 (\%)

Table 1.2. Comparison of the share of selected Asian countries in total exports in 1995 and 2016.

Table 2.1. Corporate capital system

Table 2.2. Asian TNCs in the top 100 of The Global 2000 (2018) on the background of Top10 ranking

Table 2.3. Asian TNCs in the top 100 of The Global 2000 (2012) on the background of Top10 ranking

Table 2.4. Asian TNCs in the top 100 of The Global 2000 (2006) on the background of Top10 ranking

Table 2.5. Asian TNCs in Top100 most powerful non-financial transnational corporations by foreign assets in 2018, 2012, 2006 according to World Investment Report (UNCTAD) .....

Table 2.6. Asian brands among the most valuable global brands - (values given in billions of USD) in the years 2006-2018 according to The Best Global Brands (Top 100 Brands) .....

Table 2.7. The most admired Asian automotive corporations (against the ranking leader) according to The World's Most Admired Companies in the years 2006-2018

Table 2.8. The most admired Asian electronics corporations (against the ranking leader) according to The World's Most Admired Companies in the years 2006-2018

Table 2.9. The most admired Asian computer corporations (against the ranking leader) according to The World's Most Admired Companies in the years 2006-2018

Table 2.10. Synthetic indicator (SICAV) for the examined group of automotive sector TNCS ...

Table 2.11. Synthetic indicator (SICAV) for the examined group of electronic sector TNCs ....

Table 3.1. Basic statistics on Chinese FDI in the period 2000-2017

Table 3.2. Average values of basic statistics for Chinese CBM\&As networks in 2000-2017 ..... 67

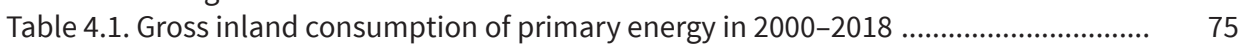

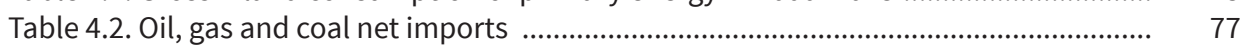

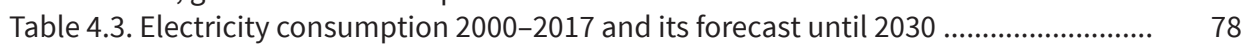

Table 4.4. $\mathrm{CO}_{2}$-emissions of China 2000-2017 and their forecast until 2030 ............................ 80

Table 4.5. Fuel structure of electricity generation in China 2000-2017 and its forecast until 2030

Table 5.1. Classification for values of the Spearman's rank correlation coefficient in terms of the strength of the correlation dependence

Table 5.2. General government final consumption expenditure in China and nine ASEAN member states in the years 2008-2017 - share in GDP (\%) 
Table 5.3. Relationship between gross domestic product and general government final consumption expenditure in China and nine ASEAN member states in the years 2008-2017 - Spearman's rank correlation coefficient [-]

Table 5.4. Economic efficiency in terms of gross domestic product while minimizing general government final consumption expenditure in China and nine ASEAN member states in the years 2008-2017 - DEA efficiency measure [-] 
http://www.instytutgm.uni.lodz.pl/about/the-department-of-international-business-and-trade

Magdalena Rosińska-Bukowska, Klaudia Zielińska-Lont - University of Lodz Faculty of Economics and Sociology, Department of International Business and Trade 90-255 Lodz, 3/5 POW Street

\author{
INITIATING EDITOR \\ Beata Koźniewska \\ REVIEWER \\ Stawomir Bukowski \\ TYPESETTING \\ AGENT PR \\ TECHNICAL EDITOR \\ Anna Sońta \\ COVER DESIGN \\ Agencja Reklamowa efectoro
}

Cover Image: @ Depositphotos.com/Nighttampa7597

http://dx.doi.org/10.18778/8142-990-0

(c) Copyright by Authors, tódź 2020

(c) Copyright for this edition by University of Łódź, Łódź 2020

Published by Łódź University Press

First edition. W.09455.19.0.K

Publisher's sheets 8.0; printing sheets 8.625

e-ISBN 978-83-8142-990-0

Łódź University Press

90-131 Łódź, 8 Lindleya St.

www.wydawnictwo.uni.lodz.pl

e-mail:ksiegarnia@uni.lodz.pl

phone. (42) 6655863 